\title{
14. SEDIMENTARY EVOLUTION OF THE JAPAN FORE-ARC REGION OFF NORTHERN HONSHU, LEGS 56 AND 57, DEEP SEA DRILLING PROJECT
}

\author{
Michael A. Arthur, U.S. Geological Survey, Denver, Colorado \\ Roland von Huene, U.S. Geological Survey, Menlo Park, California \\ and \\ Charles G. Adelseck, Jr., Scripps Institution of Oceanography, La Jolla, California
}

\begin{abstract}
The evolution of Neogene and Quaternary sedimentation in the fore-arc region off northern Honshu is evaluated using multichannel and single-channel seismic records in conjunction with the drill holes of the Japan Trench Transect (DSDP/IPOD Legs 56-57). The outer forearc region, which consisted of older sedimentary rocks and some calc-alkaline volcanic rocks, was subaerially exposed and eroded during the Paleogene and part of the Neogene. The deep sea terrace (fore-arc basin) region subsided below sea level in the early Miocene; most rapid subsidence occurred during the early to middle Miocene. Submergence progressed seaward so that the last vestige of the Oyashio landmass, which is now under the upper trench slope; was below sea level in the latest Miocene. Sediment sources to the outer fore-arc basin changed progressively from lithic, predominantly nonvolcanic material derived from the uplifted landmass during the late Paleogene-early Neogene to volcanic, arc-derived sediment rich in volcanic glass, plagioclase, and volcanic lithic fragments. The volcaniclastic sediment was probably derived both from Honshu to the west and Hokkaido to the northwest.

In response to subsidence the sedimentary depocenters in the fore-arc basin migrated generally seaward through time; the greatest relative seaward migration occurred between the late Miocene and Pliocene. Thick sediment sequences accumulated in slope basins on the trench inner slope. Sediment from the arc moved seaward to spill over the slope via large channels.

An abrupt change in morphology and patterns of sedimentation apparently took place in the late Pliocene, coincident with a peak in explosive volcanism recorded in the form of ash layers and increased glass contents in sediment. The deep sea terrace was uplifted several hundreds of meters and a major channel crossing the fore-arc region was tilted landward and filled. At about the same time the midslope terrace basin was created and began rapidly accumulating sediment. The older basins, lower on the trench inner slope, were destroyed, possibly by steep seaward tilting, or filled. Large slump masses were sloughed-off downslope to the trench. Little sediment now accumulates on the trench inner slope in the vicinity of the sites, and older strata crop out on the slope. The locus of deposition has shifted northward off Hokkaido where a large channel feeds sediment to the slope. Large slump masses now fill the trench and are being accreted, creating a "toe" to the slope in this region.

The evolution of the fore-arc region off northern Honshu has not been steady state. Tectonic accretion has been discontinuous, and tectonic erosion of the continental margin edge may have occurred periodically. Slope basins have been both created and abruptly destroyed at different points on the trench inner slope. There appears to be little possibility of distinguishing most sediment "scraped off" the oceanic plate from hemipelagic sediment deposited in the fore-arc region of Japan.
\end{abstract}

\section{INTRODUCTION}

The distribution of sediment across a convergent margin has become increasingly important to the understanding of ancient folded belts that rim most of the Pacific Ocean. Since the general acceptance of the plate tectonic theory, many Pacific fold belts have been reinterpreted applying the simple plate tectonic concept to previously observed geologic data (see review, Dickinson and Seely, 1979). The data are by their nature commonly fragmentary and obscure because of numerous tectonic overprints, discontinuity of exposure, and complex structure. The assignment of a depositional environment to the various metamorphosed rocks in a complexly folded section many kilometers thick is at best problematical. Thus the reconstruction of an ancient convergent margin often involves multiple inference, first in the sedimentary model and second in piecing together all of the time equivalent rock units. Certainly an actualistic modern analogue of sedimentation across a convergent margin would be more desirable than an inferred one.

A considerable amount of the knowledge about modern margin sediment distribution has been derived from geophysical records. For instance, the layer of "acoustically transparent"' sediment which conforms to topography on the seaward side of a trench is assumed to be pelagic, comprising oxidized clay and biogenic ooze, and the ponded sediment filling a trench axis is commonly assumed to consist of coarse-grained sediment 
(Scholl et al., 1977). Few actual samples have been obtained across a single active margin to determine such important sedimentary processes as rates of deposition, composition, and comparative sediment volumes.

The experience gained through combining drilling and geophysical data suggests that morphotectonic patterns and sedimentary processes are sufficiently complex to require extensive drilling and geophysical analysis if we expect to develop a comprehensive model of sediment distribution across modern convergent margins. The Japan Trench Transect (Legs 56 and 57) provides one of the most complete sets of data for use in reconstructing the sedimentary processes across one section of a convergent margin. Seven sites were drilled along track lines of multichannel seismic data which had been obtained from the study of a grid of existing singlechannel seismic records together with other geophyscial data. Sediment was recovered in a transect of sites from the fore-arc basin, the trench inner slope, a slope basin, and from the deep ocean basin seaward of the trench. Quaternary sediment in the trench axis has been sampled by piston coring (Inouchi et al., 1977).

In this chapter we synthesize the sedimentological data from our studies and those of our colleagues. We use the combined geophysical and drill data to describe the evolution of sediment compositions, sedimentary patterns, and processes from Paleogene through Recent time and to emphasize the complexity of this sedimentary regime. In particular we examine the variability in sedimentation and sediment composition along all parts of the margin, the sudden changes in sedimentary style, changes in morphotectonic features, and the similarity between sediment landward and seaward of the trench axis. We discuss tectonic events only insofar as they explain sedimentation; the reader is referred to a more detailed discussion of tectonic evolution and interpretation of seismic records in von Huene et al. and Nasu et al. (both in this volume, Pt. 2).

\section{GEOLOGIC SETTING}

The Japan Trench Transect crosses a fore-arc system from the Pacific shore of northern Honshu across the trench and into the adjacent Pacific Ocean basin. The fore-arc basin, named the Ishikari-Hidaka Basin, extends from the northwest coast of Hokkaido more than $600 \mathrm{~km}$ to the south and is filled with Neogene sediment as much as $5 \mathrm{~km}$ thick (Ishiwada and Ogawa, 1976). Sites 438 and 439 on the deep sea terrace (Figure 1) are on the southern edge of the Ishikari-Hidaka Basin, where the Neogene section is about $1.5 \mathrm{~km}$ thick. The sites are on the south flank of a small circular knoll, Hachinohe Knoll, which was a structural high throughout the Neogene. The reflective sequence in multichannel seismic profiles (Figure 2) above a major diffracting horizon represents a seaward transgressive sequence across an extensive angular unconformity. Landward-dipping reflectors below the unconformity may represent formerly accreted sediment or folded and tilted older Sedimentary rocks; they are dated by drilling as Upper Cretaceous at Site 439. The Neogene sequence is cut by landward-dipping normal faults spaced about 10 to $15 \mathrm{~km}$ apart (Nasu et al., this volume). Seismic refraction measurements indicate a continental crustal velocity structure beneath the deep sea terrace (Nagumo et al., Murauchi and Ludwig, both this volume).

The trench inner slope is divided into an upper and lower part by a narrow but extensive midslope terrace (Figure 1). The drill sites on the slope are on all three morphologic elements. Site 435 , on the trench upper slope, sampled a sequence of near-horizontal strata. At Site 440 , on the midslope terrace, the upper part of a more than 1-km-thick sequence of weak but horizontal reflections was penetrated to a depth of about 800 meters. These reflections are in a tectonically isolated block and cannot be traced seismically to other sites. The seismic records across Sites 441 and 434 are largely obscured by diffractions, but seismic refraction measurements indicate a thick, low-velocity sediment sequence lying above oceanic crust. Weak, discontinuous reflections indicate an upper sequence with bedding subparallel to the sea floor and a lower sequence that has been tilted landward. The upper sequence consists of slope deposits, whereas the lower sequence is interpreted as a subduction-accretion complex or accretionary prism (Karig and Sharman, 1975).

The trench axis exhibits horizontal reflections representing a sedimentary fill only locally. The trench outer slope is broken by a series of normal faults (Ludwig and others, 1966), and single-channel records show a "transparent" layer of uniform thickness that generally follows the basement topography except at seamounts. The crust here is oceanic (Murauchi and Ludwig, this volume).

\section{COMPARATIVE LITHOLOGY}

The lithostratigraphy at each site is briefly summarized to provide a background for comparison of sedimentation across the transect (see Table 1 and foldouts, back pocket, Pt. 1). Age correlations, general lithology, and recovery at all sites are shown in Figure 3.

\section{Sites 438 and 439}

Sites 438 and 439 penetrated a nearly continuous section of Holocene through upper Oligocene mostly diatomaceous and vitric mudstones unconformably overlying tilted and folded mudstones of Upper Cretaceous age. The section is divided into four lithological units.

Unit 1 is upper Pliocene through Holocene. It is 52 to 107 meters thick and consists of diatomaceous sandy silty clay, silt, and numerous ash layers.

Unit 2 is 765 meters thick and consists of (1) lower through upper Pliocene clayey diatomaceous ooze and diatomaceous clay with numerous ash horizons and occasional erratic pebbles; (2) upper Miocene through lower Pliocene diatomaceous claystone (Figure 4) and clayey diatomite, with minor ash in the upper portion; (3) middle to upper Miocene claystone and diatomaceous claystone with dewatering structures and microfaults. This calcareous concretions and thin limestone beds are common. Foraminiferal assemblages indicate deposition in lower bathyal depths ( $>2000 \mathrm{~m})$. 


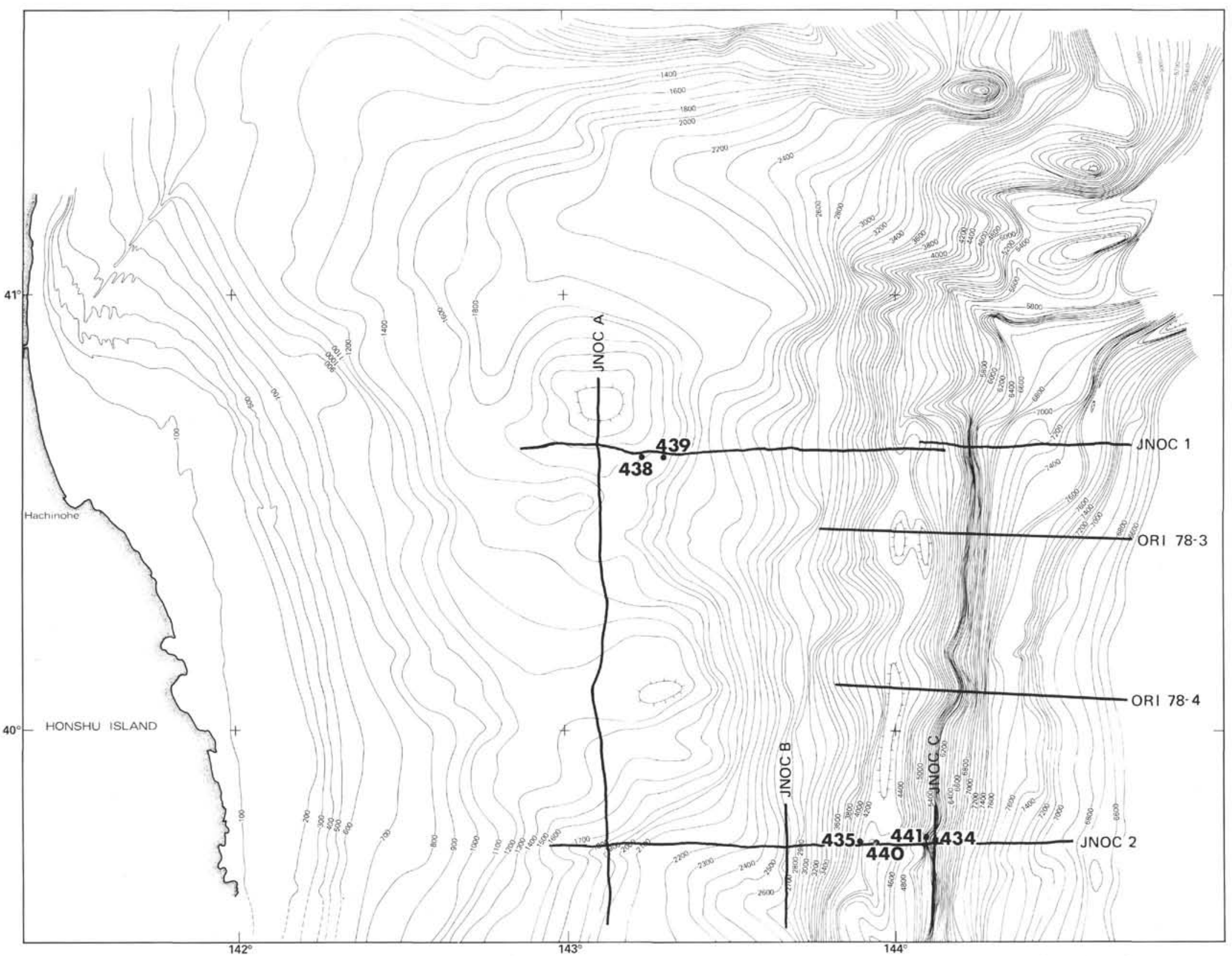

Figure 1. Bathymetric map of the fore-arc region off northern Honshu showing locations of DSDP Leg 56 and 57 sites and single and multichannel seismic lines. The map was constructed using depth data from all available seismic records and from depth surveys carried out by the Japanese Hydrographic Office (Chart No. G 1507). 

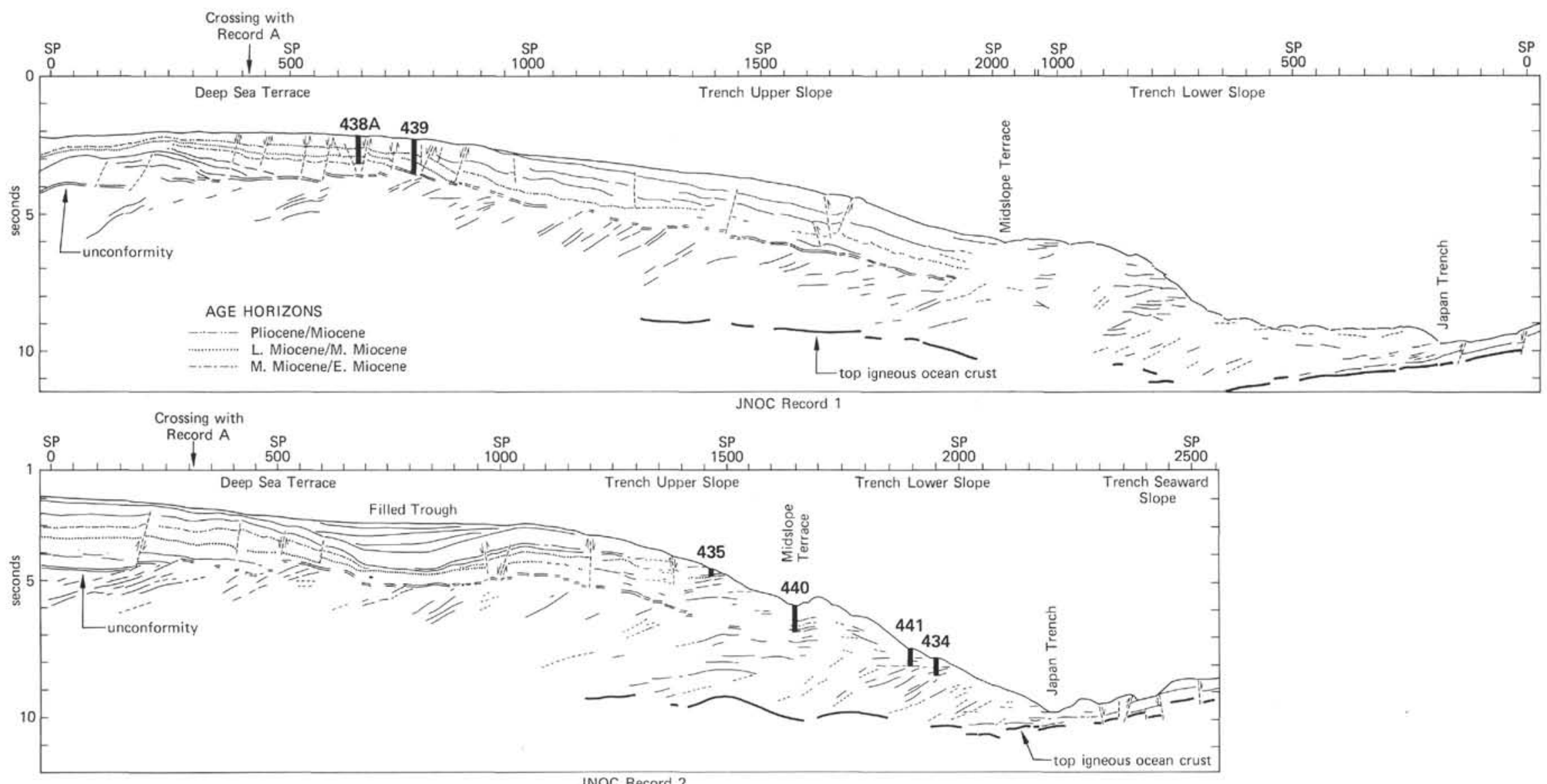

JNOC Record 2

Figure 2. Line drawings of multichannel seismic records, JNOC 1 and 2, across the fore-arc region off northern Honshu (see Figure 1 for location). Details of interpretation are given in Nasu et al. (this volume). 
TABLE 1

Lithology

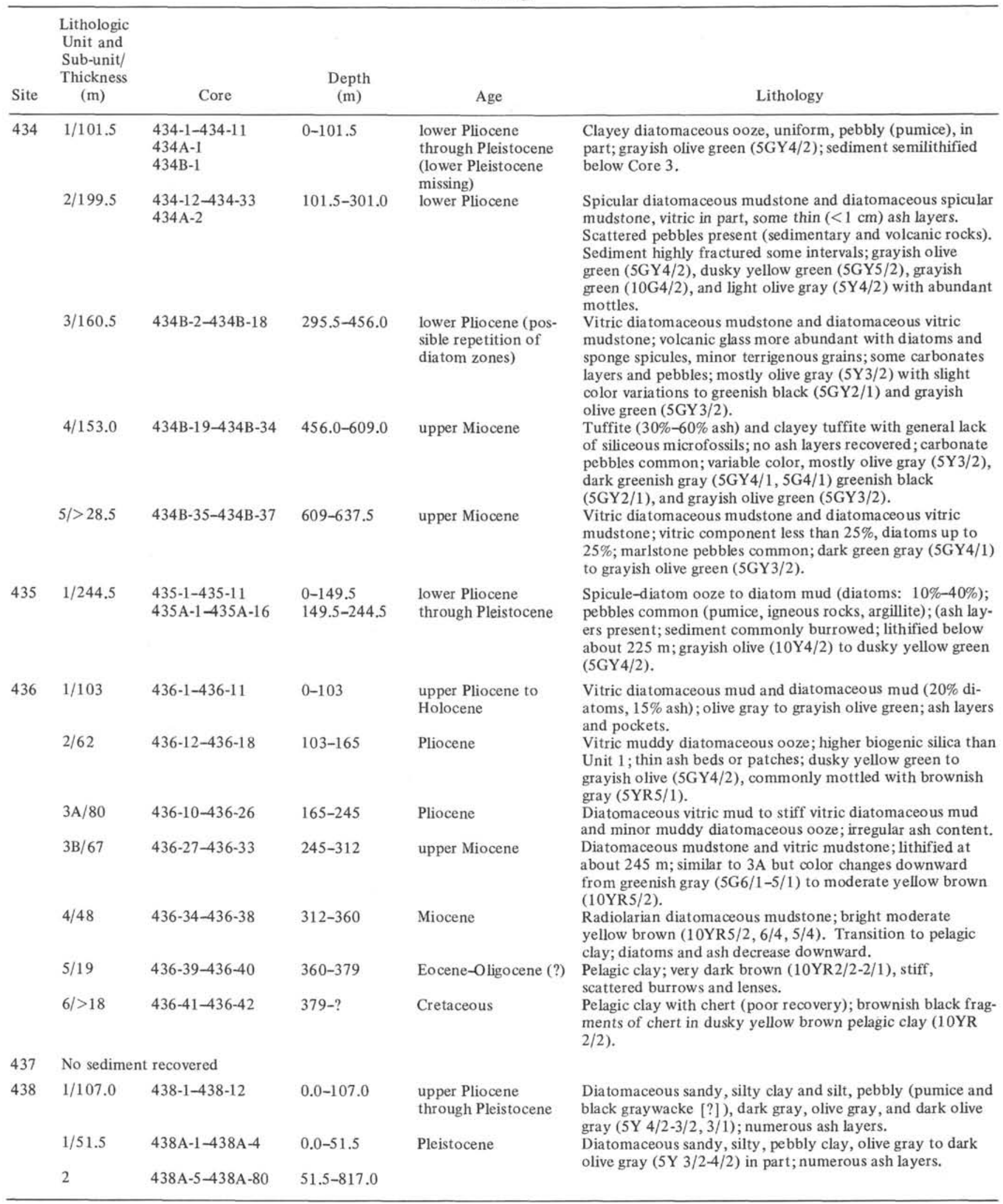


TABLE 1 - Continued

Lithologi
Unit and
Sub-unit/

Site Thickness

TABLE $1-$ Continued

Site (m)

Core $\quad(\mathrm{m})$

Age

Lithology

$438 \quad 2 \mathrm{~A} / 312.5 \quad 438 \mathrm{~A}-5-438 \mathrm{~A}-32 \quad 51.5-363.0 \quad$ lower Pliocene

(cont.)

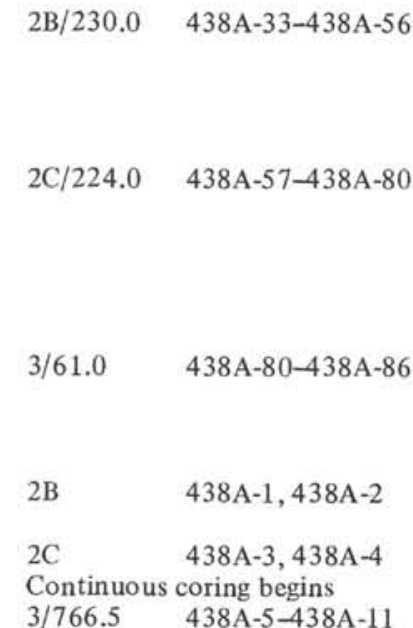

$3 / 766.5 \quad 438 \mathrm{~A}-5-438 \mathrm{~A}-11$

849.5-916.0 lower to middle Miocene

\section{$4 / 77.5$}

438A-12-438A-22 (Section 1)

through
Pliocene

upper Miocene through lower

Pliocene

(lowermost)

$593.0-817.0$

middle Miocene through lower upper Miocene

$817.0-878.0$ lower middle Miocene

hiatus 916.0-993.5 lower Miocene lower Miocene to

5/104.5 438A-22 (Section 2) $-438 \mathrm{~A}-32$ (Section 1) $\begin{array}{ll}6 / 47.5 & 438 \mathrm{~A}-32 \text { (Section } \\ \text { 2)-438A-37 (Sec- }\end{array}$ tion 1)

7

438A-37 (Section 2) $-438 \mathrm{~A}-39$

440 1
993.5-1098.0 Oligocene

1098.0-1145.5 Oligocene(?)

hiatus

1145.5-1156.5 Cretaceous

$0.0-38.0$
Holocene-upper Pleistocene
Homogeneous to burrow-mottled (lower part) clayey diatom ooze, diatom ooze, and diatomaceous clay (soft to firm), mostly olive gray (5Y 4/2) with dark and very dark gray intervals ( 5 Y $5 / 3$ ); numerous ash horizons (green gray to gray), occasional pebbles (pumice), and siliceous sponge remains.

Diatomaceous claystone, clayey diatomite (silicified), burrow-mottled throughout, minor ash layers in upper portion. Most of sub-unit is olive gray, dark olive gray, gray to very dark gray. Sponge remains occur only in upper part. Lower part of sub-unit silicified. Rare pebbles (pumice). Mostly burrow-mottled claystone and diatomaceous claystone showing dewatering structures and some microfaults. Thin calcareous concretions and thin limestone beds common. Pebbles (pumice) and ash horizons rare. Sub-unit $2 \mathrm{C}$ is predominantly dark gray, gray, and gray green ( $5 \mathrm{Y} 4 / 1-$ $5 / 1$, and 5 GY $5 / 1-4 / 1$ ).

Sandy claystone and diatomaceous claystone, vitric in part. Clayey sandstone and siltstone alternates with claystone. Burrow-mottling common. Colors mostly gray to dark gray and gray green (5YG 5/1-4/1 and 5GY 4/1).

Overlap with Hole 438

Grayish olive green (5GY 3/2) and olive gray to dark olive gray ( 5 Y 4/2-3/1) claystone; intensely burrow-mottled ( $5 \mathrm{Y}$ $6 / 4$ and $5 Y 4 / 3$ ) concretionary limestone layers, infrequent thin tuff layers, pumice clasts and fragments, microfaults and dewatering veins, tension fractures, sharp transition to next unit below.

Interbedded turbidites and silty claystone, greenish black (5G $2 / 1,5 Y 4 / 1$ ) to olive gray, Bouma turbidite sequences are mostly "ae" with a few "ade" and "acde"; mediumgrain to fine-grain sand, silt grading upward to clay, sharp basal contacts, scoured; lithic wacke composition (microcrystalline quartz lithic fragments), some mollusc fragments. A few tuff layers, mottled clayey siltstone at base-sharp transition to next unit below.

Gray to olive gray (N5 to $5 \mathrm{Y} 4 / 1$ and $2.5 \mathrm{Y} 4 / 0$ ) massive sandstone and siltstone moderately well sor ted, friable, no sedimentary structures, abundant molluscan debris and articulated pelecypods; sandstone calcite-cemented in lowest part of unit. Wood chips, quartz, lithic fragments (sands are lithic arenites) common.

Boulder to pebble conglomerate and breccia, mostly mudsupported, angular to subrounded clasts in claysize matrix; boulder and smaller clasts of dacite (blue gray to greenish gray) and pebbles and granules of very dark gray silicified silty claystone (similar to Unit 7). Boulders up to $65 \mathrm{~cm}$ diameter. Several individual conglomerate units. Basal $60 \mathrm{~cm}$ is olive gray ( 5 Y $4 / 1$ ) plastic clay (firm).

Dark to very dark gray ( $\mathrm{n} 4$ to N2) well-indurated, silicified claystone and clayey siltstone with thin $(<1 \mathrm{~cm})$ calcareous graded silt beds; contorted into slump folds but some horizontal bedding.

Greenish black to olive gray ( $5 \mathrm{G} 2 / 1$ to $5 Y 4 / 2$ ) clayey sand and gravel, poorly sorted, from dusky yellow green to olive gray (5GY $5 / 2$ to $5 Y 3 / 2$ ) diatomaceous clay, sandy diatom ooze and grayish olive (10Y 4/2) diatomaceous silty and sandy clay; some graded bedding in coarser-grained intervals. Rounded pebbles of various igneous and sedimentary rocks common. Some thin ash layers. 
TABLE 1 - Continued

\begin{tabular}{|c|c|c|c|c|c|}
\hline Site & $\begin{array}{c}\text { Lithologic } \\
\text { Unit and } \\
\text { Sub-unit/ } \\
\text { Thickness } \\
\text { (m) }\end{array}$ & Core & $\begin{array}{l}\text { Depth } \\
\text { (m) }\end{array}$ & Age & Lithology \\
\hline $\begin{array}{l}440 \\
\text { (cont.) }\end{array}$ & 2 & $440-5-440-26$ & $38.0-380.0$ & $\begin{array}{l}\text { lower Pliocene- } \\
\text { upper Pliocene }\end{array}$ & $\begin{array}{l}\text { Mostly dark olive gray to olive gray ( } 5 \text { Y } 3 / 2-4 / 2) \text { diatoma- } \\
\text { ceous clay and (below } 168 \mathrm{~m} \text { ) diatomaceous claystone. } \\
\text { Randomly dispersed rounded pebbles common; burrow } \\
\text { mottling increases downhole. Minor thin ash layers. }\end{array}$ \\
\hline 441 & 1 & $\begin{array}{l}441-1-441-6 \\
441 A-1-441 A-2\end{array}$ & $0.0-132.0$ & $\begin{array}{l}\text { Pleistocene-upper } \\
\text { Pliocene }\end{array}$ & $\begin{array}{l}\text { Dark greenish gray ( } 5 \mathrm{GY} 4 / 1) \text { silty diatomaceous clay at } \\
\text { top, predominantly olive gray ( } 5 \text { Y } 4 / 2 \text { ) diatomaceous clay } \\
\text { with minor ash layers; rounded pebbles up to } 2 \mathrm{~cm} \text { diameter } \\
\text { consisting of basalt, dacite, pumice, and some calcareous } \\
\text { pebbles or concretions. Minor clayey silt or sand layers. } \\
\text { Slightly mottled throughout. One graded silty tuffite noted } \\
\text { at base of Unit } 1 \text {. }\end{array}$ \\
\hline & 3 & $441 \mathrm{~A}-5$ & $380.0-410.0$ & lower Pliocene & $\begin{array}{l}\text { Breccia of dark gray (N3) siltstone: rounded to angular silt- } \\
\text { stone fragments in more clay-rich matrix or gouge. Dewa- } \\
\text { tering veins at tip of unit recovered. Several graded and un- } \\
\text { graded very fine-grained to coarse-grained sandstone } \\
\text { interbedded with claystone ( } 5 \mathrm{Y} \text { - } 6 / 1 \text { ). Bottom of unit cho- } \\
\text { sen on basis of signature on geophysical log (FTC). Fair } \\
\text { recovery. }\end{array}$ \\
\hline & 4 & $441 \mathrm{~A}-6,441 \mathrm{~A}-7$ & $410.0-504.0$ & lower Pliocene & $\begin{array}{l}\text { Mostly olive gray }(5 Y 3 / 2) \text { diatomaceous claystone and } \\
\text { claystone, some siltstone, possible redeposited claystone, } \\
\text { minor tuff layers, and calcareous concretions; poor recovery } \\
\text { and highly fractured material. }\end{array}$ \\
\hline
\end{tabular}

aH signifies "wash cores," sediment cored through an interval longer than the core barrel. These are archived and sampled as a normal cores.

Unit 3, lower Miocene, is about 120 meters thick and consists of vitric sandy claystone (Figure 5) and diatomaceous claystone.

Unit 4 is lower Miocene. It consists of 77 meters of well-indurated clayey siltstone (Figure 6). The lower part of Unit 4 at Site 439 is a fine-grained turbiditeclaystone sequence of lowest Miocene age, containing a middle bathyal $(500-1500 \mathrm{~m})$ benthic foraminiferal assemblage (Figure 7A-C).

Unit 5 is a 105-meter-thick massive sandstone and siltstone of Oligocene age, probably deposited near shore (Figure 7D). The unit contains numerous megafossils, including articulated pelecypods (not in growth position), virtually unbroken gastropods, and upper bathyal $(200-500 \mathrm{~m})$ benthic foraminifers.
Unit 6 consists of conglomerate and breccia (Figure 7E) made up largely of boulders of porphyritic dacite (Figure 7F). The angular shape of some of the dacite clasts, their large size (up to 1.5 in diameter), and the nearly monolithologic composition of the breccia indicate a nearby source of hypabyssal volanic rocks and possibly thick flows. The conglomerate might have formed subaerially, an inference based on the lack of marine fossils and an underlying soft clay layer that may have formed during subaerial weathering.

Unit 7 is an indurated, dark silicified silty claystone of Upper Cretaceous age. Thin silt turbidite layers (Figure 7G) define bedding and synsedimentary as well as possible tectonic folds. An erosion surface is inferred at the top of the claystone because (1) at least 40 million 


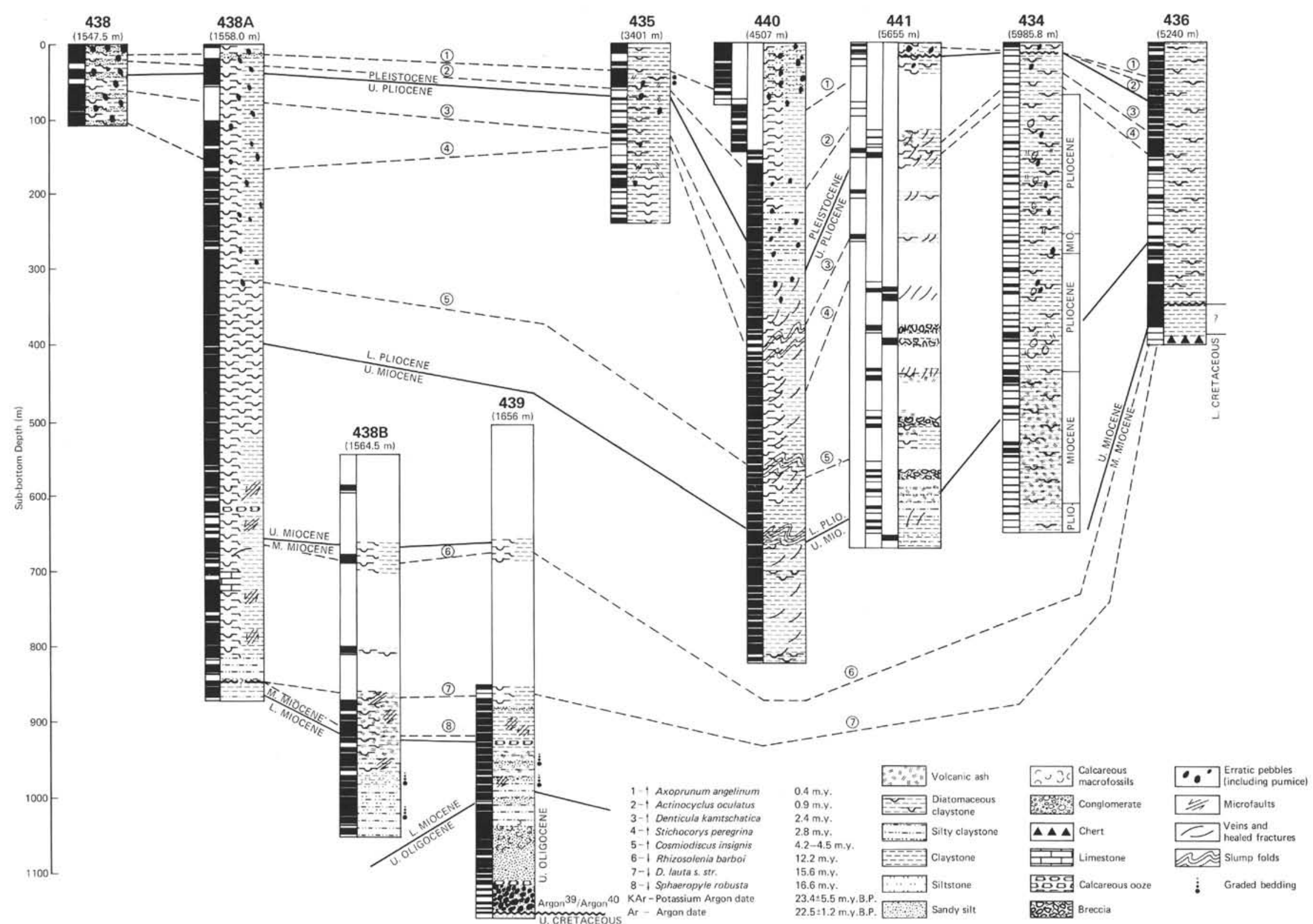




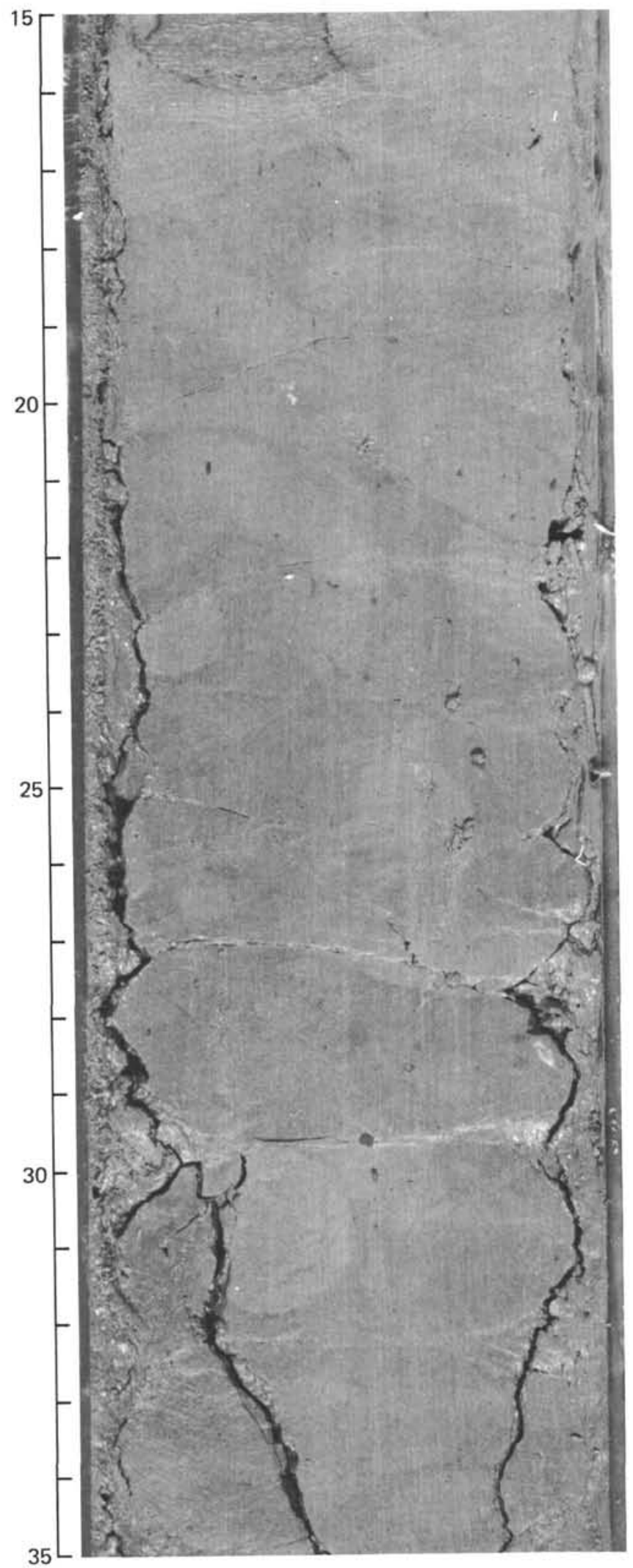

Figure 4. Leg 57, Sample 438A-39-1, 15-35 cm: upper Miocene medium gray $(5 Y 5 / 1)$, intensely but subtly mottled clayey calcareous diatomite; typical appearance of most undeformed Neogene muddy sediment in Legs 56 and 57 sites.

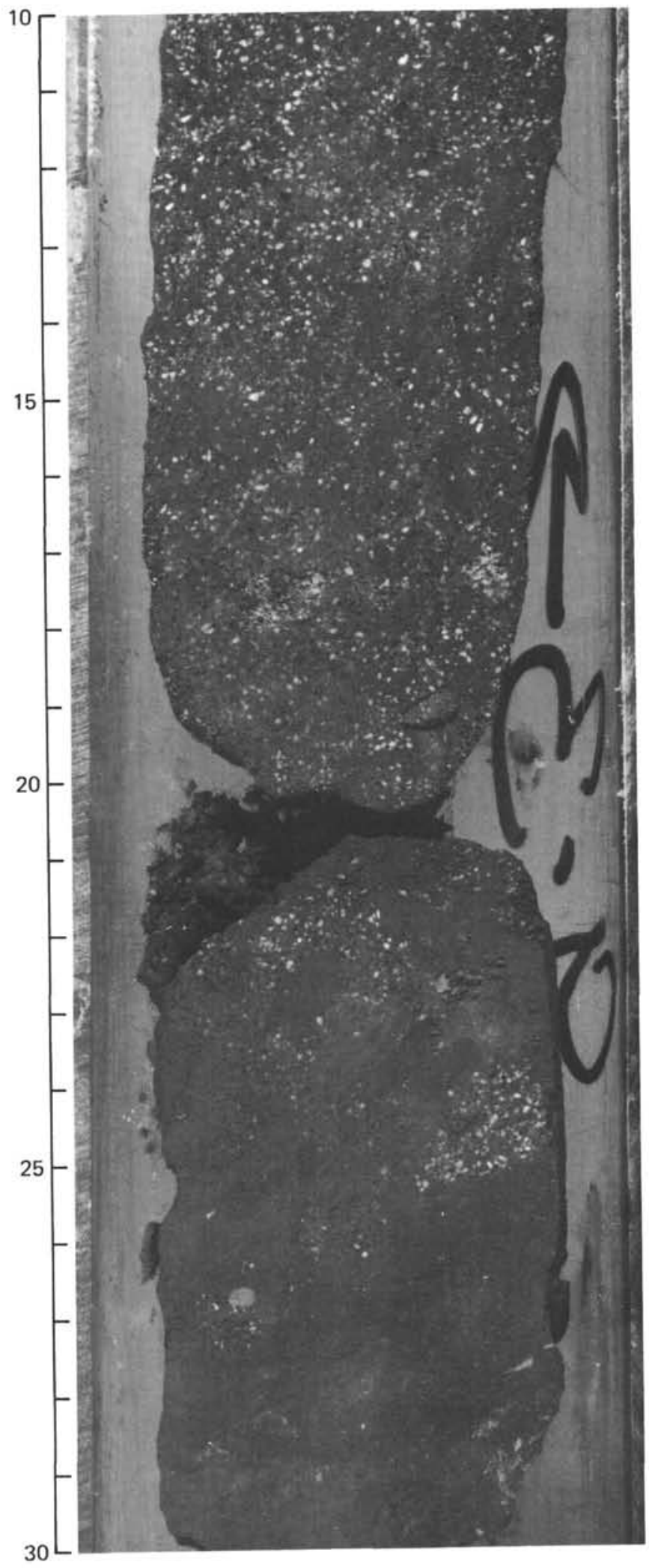

Figure 5. Leg 57, Sample 438B-9-3, 10-30 cm: lower Miocene olive gray (5Y 4/2) vitric silty, sandy claystone; moderately mottled. Contains coarser frugments of volcanic material. 


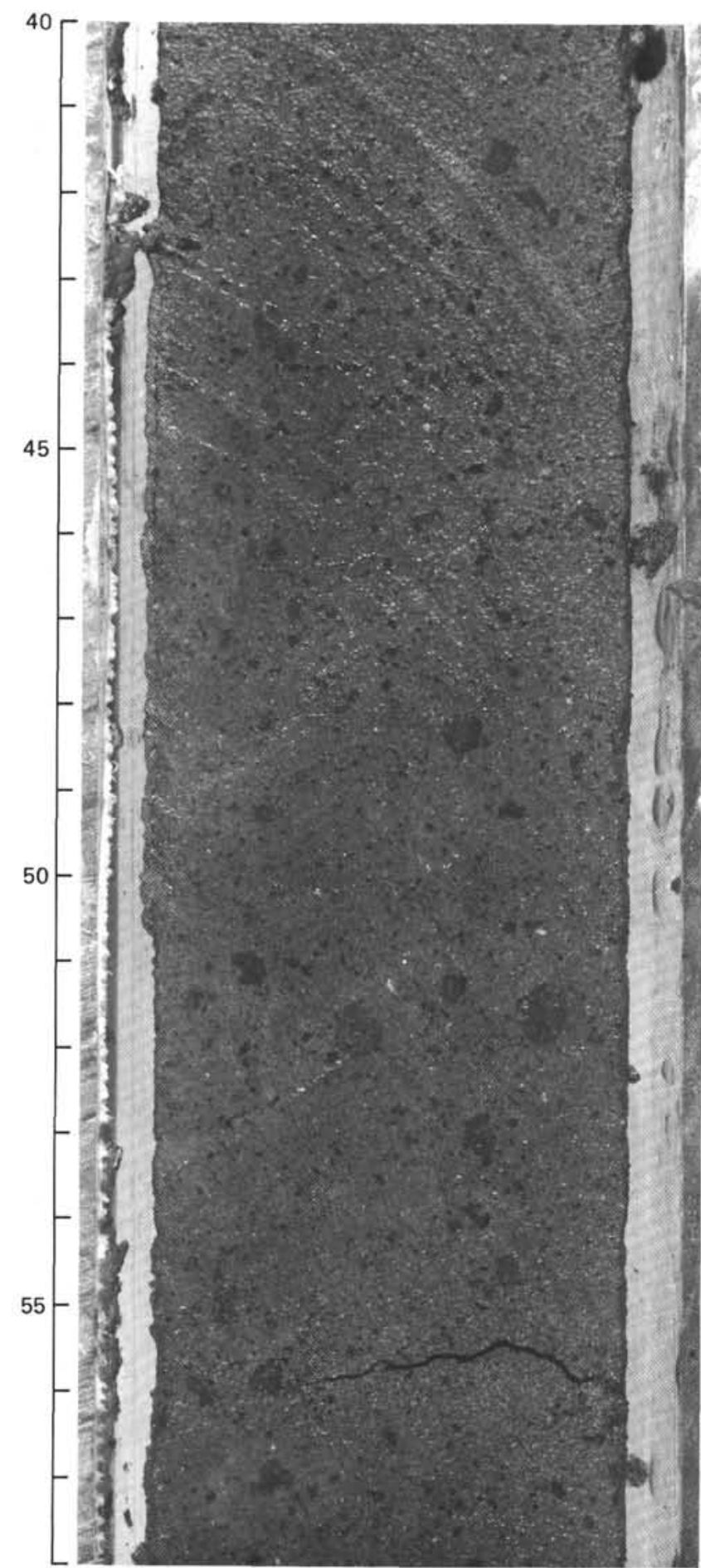

Figure 6. Leg 57, Sample 438B-20-2, 40-58 cm: lower Miocene massive olive black glauconitic, quartzose, clayey siltstone; pods and clots of glauconite. This sediment is presumably derived from the Oyashio paleolandmass.

years of sedimentary history is lost in the hiatus; (2) a rough surface topography is indicated in seismic records by a highly diffractive horizon; and (3) because the claystone is found as clasts in the overlying conglomerates and turbidites.

\section{Site $\mathbf{4 3 5}$}

At Site 435 the target was a slightly flat part of the trench upper slope where seismic records indicate outcropping beds that dip gently landward. The sedimentary section is an undisturbed hemipelagic sequence consisting of greenish gray to olive gray muddy and clayey diatomaceous ooze. Thin layers of volcanic ash and minor amounts of terrigenous sand are present. Rounded and subrounded erratic pebbles occur throughout the section. With the exception of two layers of volcaniclastic sand, no significant amounts of coarse-grained terrigenous sediments were found.

The ages of the section (diatom and radiolarian zones) are Pleistocene, 0 to 84 meters; late Pliocene, 84 to 110 meters; and early Pliocene, 110 to 245 meters. Benthic foraminifers indicate that the sediments at this site have been uplifted during the late Pliocene and Pleistocene.

\section{Site 440}

The composition of sediment at Site 440 is very similar to that at Sites 438 and 439 (Figure 2, Table 1). The uppermost unit, 38 meters thick, is late Pleistocene and contains poorly sorted, graded beds of clay, sand, and gravel between layers of diatomaceous clay and ooze. The upper half of the Unit $2(38-380 \mathrm{~m})$, of Pleistocene and late upper Pliocene age, is composed primarily of diatomaceous claystone whereas the lower half lacks a significant diatom content. The third unit (380-808 m), of early Pliocene to late Miocene age, is compositionally similar to Unit 2 but is distinguished by several possible slumped and folded intervals (Figure 8).

The Pleistocene section is 200 to 250 meters thicker than at any other site in the Japan Trench transect. This increase in thickness is probably caused by ponding of sediment on the terrace. Shelf foraminiferal assemblages are found in the upper 70 meters at this site and demonstrate that much of the sediment has been displaced downslope.

\section{Site 441}

At Site 441 the beds sampled are late Miocene to Pleistocene, with varying amounts of diatoms and volcanic ash, much the same as at other sites on this transect. Most of the Pleistocene sequence is missing, and the Pliocene is thicker than at Site 440 . Recovery was very low at this site. A sedimentary breccia consisting of mudstone chips in a mudstone matrix was recovered. In some cores the clasts were paleontologically dated as chips of lower middle Miocene rocks floating in a Pliocene matrix. In one coherent section, the lithic chips are squeezed together with little if any apparent intervening matrix (Figure 9). Also sampled was tectonic breccia that had apparently developed in place. The relative importance of each of these fabrics cannot be determined because of the highly fragmented core material and poor recovery.

\section{Site 434}

Site 434 is located on a small terrace on the trench lower slope. Drilling conditions were difficult and core 
recovery was almost as poor (averaging 18 per cent) as at Site 441 (averaging 14 per cent). The lithologic section is divided into four units based on the amount of volcanic ash present. Most of the Pleistocene is missing here as at Site 441. The upper 100 meters consist of Pleistocene and Pliocene diatomaceous ooze with small amounts of clay and vitric ash. The section from 100 to 300 meters, of Pliocene age, is a highly fractured, diatom-rich mudstone. A third unit, between 300 and 460 meters, is early Pliocene and late Miocene and is characterized by a higher abundance of vitric ash. Redeposited mudstone conglomerates occur in this interval as well (Figure 10A). Between 460 and 600 meters, the sediment consists principally of volcanic ash and hence has been termed tuffite. This tuffite is late Miocene. The lowermost 30 meters of sediment is similar to that of Unit 3.

Sediment recovered consists primarily of small chips typical of hackly fracturing (Figure 10B); however, there are healed microfaults in some larger core pieces. Harper (this volume) suggests that diatom zone repetition (lower Pliocene) may be due to larger-scale faulting.

\section{Site 436}

Site 436 is located at the crest of the broad swell seaward of the Japan Trench. Over 90 per cent of the section consists of Neogene sediments, mainly highly bioturbated vitric diatomaceous muds (Figure 11) and, below 250 meters, mudstones. The ages range from Quaternary at the top to Middle Miocene at about 360 meters. Ash layers 1 to $10 \mathrm{~cm}$ thick are common throughout the Quaternary and Pliocene sections but most abundant in the Pliocene. The entire section from the middle Miocene down through the Paleogene is compressed into a 20 -meter section of dark brown manganese-rich clay containing no pelagic microfossils (Figure 12); however, numerous fish teeth and micromanganese nodules are present. The last two cores between 378.5 and 397.5 meters sub-bottom contain dark brown banded cherts and rare radiolarians of Early Cretaceous age.

\section{TRENDS IN SEDIMENT COMPOSITION AND ACCUMULATION RATES}

\section{Calculation of Accumulation Rates}

Accumulation rates for total sediment and various components of the sediment were calculated using average values for the sediment bulk density for selected intervals (see Physical Properties data in Carson and Bruns, this volume) and absolute time intervals from the biostratigraphic datums of various microfossil groups correlated to the magnetic and absolute time scales (see Biostratigraphic Summary of Barron et al., this volume). The equation used to calculate the accumulation rates is an approximation, assuming that $(1-W . C$. $) \varrho_{s}$ $=\varrho_{b}-W . C .\left(\varrho_{w}\right)$, where $W . C$. is the sediment water content, $\varrho_{s}$ is the sediment grain density, $\varrho_{b}$ is the sediment bulk density as measured, and $\varrho_{w}$ is the density of pore water (approx. $1.01 \mathrm{Mg} / \mathrm{m}^{3}$ ). The total sediment accumulation rate (sedimentation rate $[\mathrm{m} / \mathrm{m} . \mathrm{y}.] \times \varrho_{b}$
$\left.-W . C .\left[\varrho_{w}\right]\right)$ is then multiplied by the average percentage of each component over a given interval; this gives a value in $\mathrm{Mg} / \mathrm{m}^{2} / \mathrm{m}$.y. (equivalent to $\mathrm{g} / \mathrm{cm}^{2} / \mathrm{m}$.y.). Contents of volcanic glass and diatoms are estimated on the basis of smear slide studies; the values are based on estimates of areal or volume percentage and are subject to operator bias. They are treated here as weight percentages, which will tend to overestimate their abundance.

\section{Total Sediment Accumulation Rates}

The rate of accumulation of sediment varies from 0 to $328 \mathrm{Mg} / \mathrm{m}^{2} / \mathrm{m}$.y. Rates at Sites 438 and 439,435 , and 436 are very similar, averaging about 40 to 50 $\mathrm{Mg} / \mathrm{m}^{2} / \mathrm{m}$.y. The total accumulation rates are much higher (generally over a factor of 2) at the trench inner slope sites-440, 441, and 434-than at the other sites. Most of the total rate at each site is due to sedimentation of terrigenous clastic material (clay minerals, silt, and sand). Figure 13 illustrates the total rates and shows the accumulation rates of biogenic silica (primarily diatoms) and ash which compose the remainder of the sediment in order of abundance. Carbonate contents are generally low.

At Site 438 there are two brief periods of relatively high clastic input: middle Miocene (14-16 m.y.B.P.) and Pliocene (2-5 m.y.B.P.). The middle Miocene peak coincides with higher than normal accumulation rates of biogenic silica and volcanic ash whereas the Pliocene peak coincides only with increased diatom flux (Figure 13). Accumulation rates are relatively constant for the remainder of time with the exception of brief hiatuses in the late middle and late Miocene. Site 435 shows relatively constant and low accumulation rates of terrigenous material throughout. Site 436 is characterized by a low but gradually increasing flux of terrigenous material to a Plio-Pleistocene high as the oceanic plate converged with the Japan continental margin.

Site 440 had relatively high but constant rates of accumulation of clastic material which increased abruptly (nearly doubled) during the late Pleistocene. This probably represents the ponding of clastic material after the formation of the midslope terrace. Sites 441 and 434 both had high accumulation rates of terrigenous clastic material during the late Miocene-early Pliocene, generally higher than those at Site 440 . The rates were drastically reduced during the late Pliocene at Site 434 , and the Pleistocene is missing at both Sites 434 and 441 .

It appears therefore that most terrigenous sediment was trapped on the lower trench inner slope during the late Miocene and Pliocene but that the high accumulation shifted to the midslope terrace in the Pleistocene. Sites 438 and 435 , on the deep sea terrace and upper trench inner slope, respectively, were relatively isolated from influx of terrigenous clastic material in the late Miocene through Pleistocene.

\section{Composition of Clastic Material}

The detrital material in sediments of Legs 56 and 57 consists primarily of clay minerals and a lesser proportion of terrigenous silt and sand, although some of the volcanic glass may be detrital as well (see section on 
M. A. ARTHUR, R. VON HUENE, C. G. ADELSECK, JR.
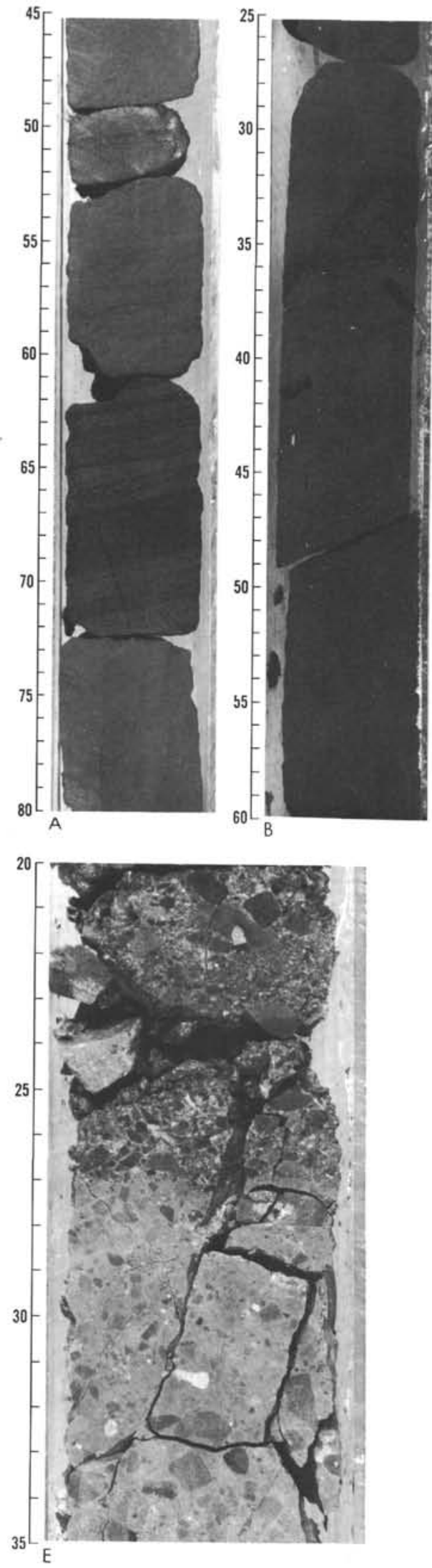
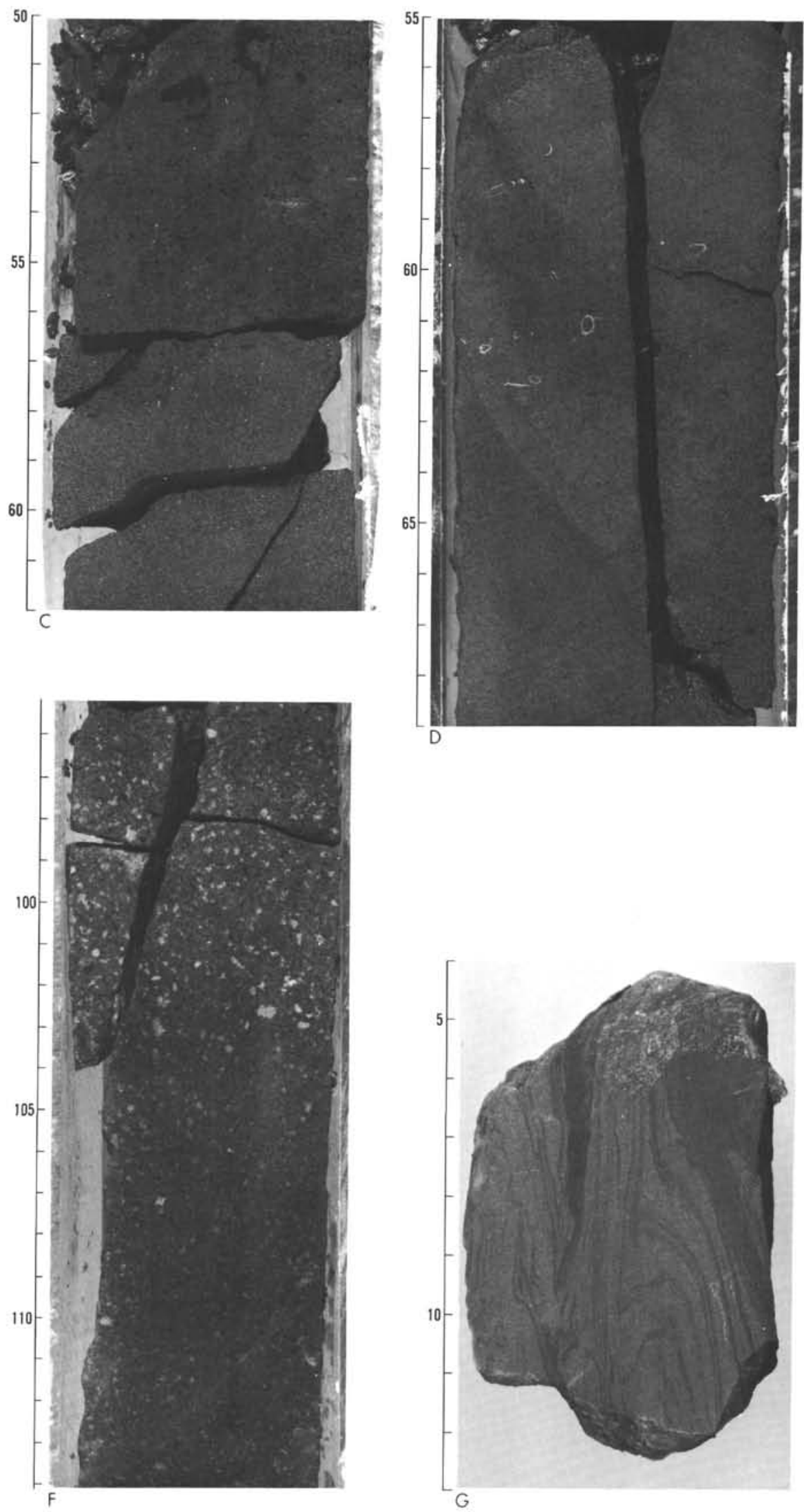
Figure 7. A. Leg 57, Sample 439-15-3, 45-80 cm: lower Miocene olive gray silty sandstone; inclined lamination and faint textural grading. One of numerous turbidite sequences. Note dewatering veins in mudstone below but absence of veins in sandstone (one minor fault occurs at base). Contact is disturbed by drilling. Sand contains shale, lithic fragments, quartz, and minor feldspar. B. Leg 57, Sample 439-18-2, 25-60 cm: lower Miocene dark olive gray graded sandstone and silty claystone; note sharp, scoured based contact with underlying mudstone. Upper part of sequence is faulted and contains 1-2 cm shale clasts (lithology similar to Cretaceous dark shales recovered at base of hole) and abundant wood chips. C. Leg 57, Sample 439-19-1, 50-62 cm: lower Miocene dark olive green graded sandstone containing shale chips and wood fragments. Minor faults occur in the upper part. D. Leg 57, Sample 439-22-4, 55-69 cm: upper Oligocene massive medium-gray coarse-grained siltstone and fine-grained sandstone containing articulated pelecypods and gastropods. Lithic, fragment-rich quartzose sandstone. Lithic fragments consist primarily of shale, carbonate, and chert, with minor altered volcanic rocks. E. Leg 57, Sample 439-34-1, 20-35 cm: upper Oligocene nonmarine conglomerate-breccia unit containing angular clasts of fine-grained, predominantly dacitic volcanic rock and dark shale set in dark greenish gray (5G 3/1) clay matrix. F. Leg 57, Sample 439-34-2, 95-115 cm: Portion of porphyritic dacite boulder in upper Oligocene nonmarine conglomerate. Volcanic rock boulders radiometrically dated as being about 22 m.y. old (see Yanagisawa et al. and Moore and Fujioka, both this volume). G. Leg 57, Sample 439-38, CC, 5-12 cm: Upper Cretaceous thin-bedded, convolute-laminated quartzose siltstone in dark shale matrix which occurs below a pronounced unconformity. These sediments and the benthic foraminiferal assemblage have a deep-water aspect (see Keller, this volume). 

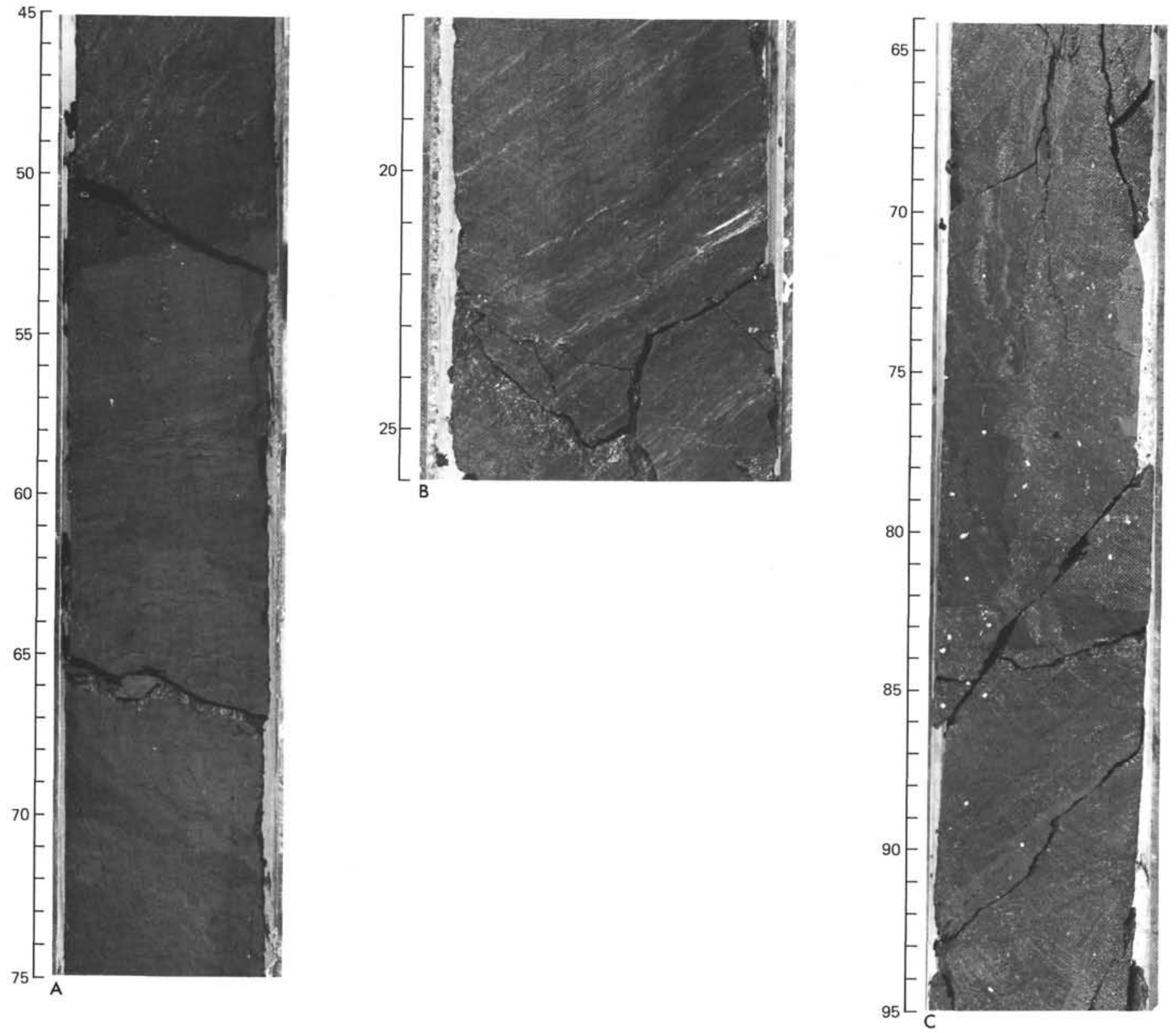

Figure 8. A. Leg 57, Sample 440B-43-3, 45-75 cm: lower Pliocene slumped olive gray diatomaceous claystone. Upper part of sequence overturned. Note discordant contact at $52 \mathrm{~cm}$ and stretched mottles of light colored ash (see part B) in mudstone above. Core of slump fold occurs at about $67 \mathrm{~cm}$. B. Leg 57, Sample 440B-43-2, 117-126 cm: Detail of stretched ash mottles in slumped unit. C. Leg 57, Sample 440B-54-3, 64-95 cm: lower Pliocene disturbed, slumped, and folded grayish olive claystone. Healed fractures with open partings parallel to fracture trend. Bedding is vertical in upper part. Fold axis is faulted at about $82 \mathrm{~cm}$.

Volcanic Components). Aoyagi and Kazama (this volume) report analyses from Sites 438,439 , and 436 which showed similar clay mineral suites consisting of montmorillonite-illite mixed layer clays, illite, chlorite, and minor detrital kaolinite. Montmorillonite was not detected below 1077 meters at Site 439. Mann and Müller (this volume) have performed $\mathrm{x}$-ray mineralogical studies of samples from all sites on the transect. They also find a great similarity between the clay mineral suites at all sites. Smectite (average 40 per cent of total clay minerals) and illite (average 35 per cent of total clay minerals) predominate, with subordinate amounts of chlorite (average 15 per cent) and kaolinite (average $<5$ per cent) in the upper Miocene through Quaternary sediment sequence at all sites, including oceanic Site 436 . The clay mineral assemblage in the Pleistocene section at Site 436, however, shows a progressive decrease in the smectite/illite ratio which may be indicative of climatic deterioration in the source region. The chlorite/ kaolinite ratio increases from about 0.2 in the Paleogene pelagic clays near the base of Site 436 to values near 3 in the upper Miocene and remains near this value through the Quaternary sediment. This may also represent progressive climate change but may be a function of the ap- 


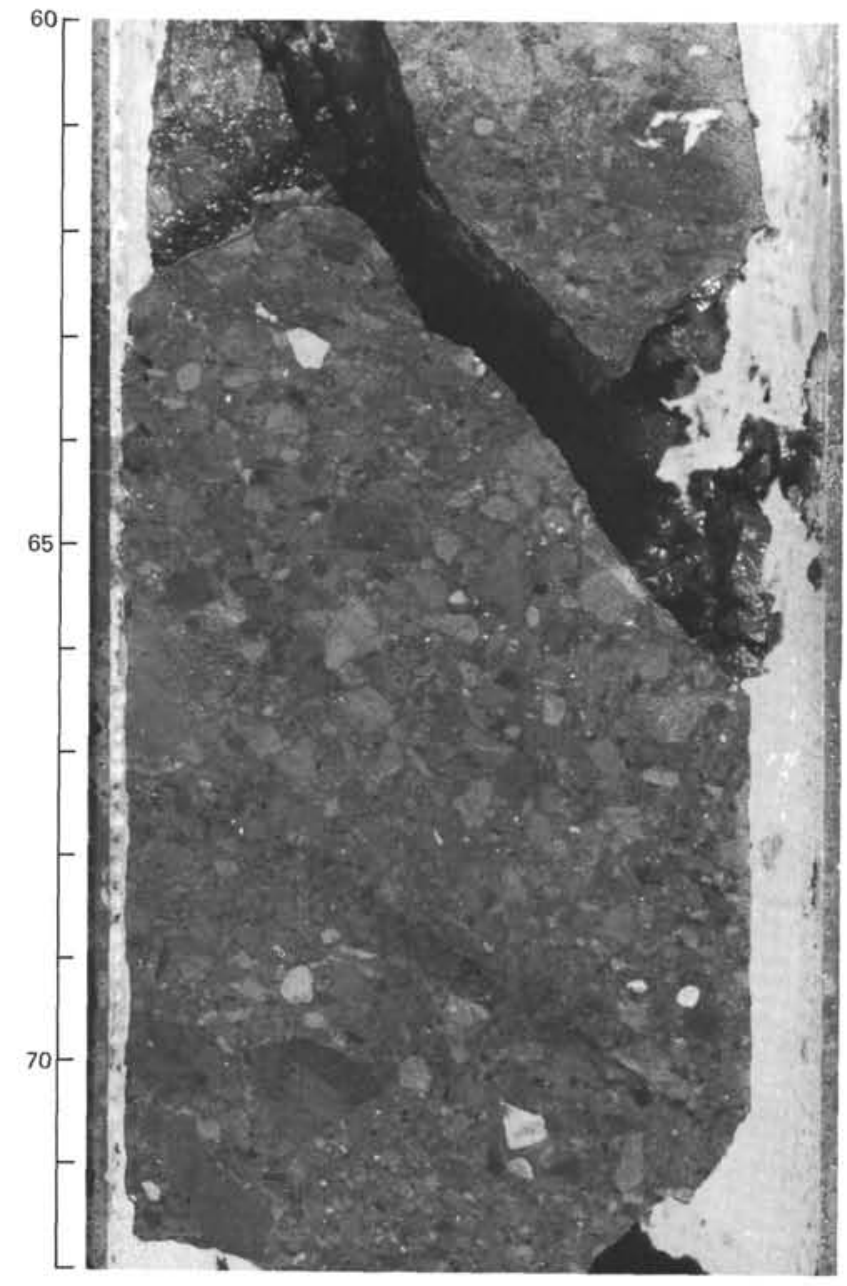

Figure 9. Leg 57, Sample 441A-11-1, 60-72 cm: upper Miocene resedimented breccia with crude stratification indicating $35^{\circ}-40^{\circ}$ dip. Clasts are angular and consist of claystone, yellow gray calcareous marlstone, olive gray claystone, glauconitic claystone, silty claystone, and white tuff. Many clasts were lithified prior to resedimentation, whereas some were soft and sutured together during compaction.

proach of the site to the Japan continent and a source of detrital chlorite as well.

Fluctuations in the proportions of the various clay minerals occur in Sites 438 and 439 as well. The smectite/illite ratio at Site 438 is somewhat variable; it is relatively high in the lower and lower middle Miocene, decreases to a low in the upper Miocene, and increases somewhat in the Plio-Pleistocene. The proportions of kaolinite and chlorite increase gradually through the lower Miocene to Pleistocene; the chlorite/kaolinite ratio is relatively high in the upper Miocene through Pliocene and decreases in the Pleistocene. At Site 439 the Oligocene sandstones and lower to middle Miocene interbedded sandstone-siltstones and mudstone are characterized by high smectite/illite ratios and high chlorite/kaolinite ratios. Smectite predominates. The proportions of quartz and feldspar also are high in Oli- gocene sediment. Opal-A, volcanic glass, pyroxene, and hornblende do not become important until the upper lower to middle Miocene sediment.

Site 435 is characterized by relatively constant proportions of smectite/illite and chlorite/kaolinite with some variation. However, the relative amounts of quartz and feldspar as well as total clay minerals and volcanic glass increase abruptly in the uppermost Pliocene. Site 440 is much like Site 438 in clay mineral assemblage and proportion. The smectite/illite ratio is relatively low during the upper Miocene-Pliocene and is higher in the Pleistocene. The chlorite/kaolinite ratio reflects the same trend. Quartz and feldspar and volcanic glass plus clay also abruptly increase in the lower Pleistocene.

There is little data from Site 441 , but Site 434 shows high proportions of volcanic glass plus clay minerals throughout the sequence and relatively constant amounts of quartz and feldspar. The smectite/illite and chlorite/kaolinite ratios are variable but show no consistent trends.

Mann and Müller (this volume) have also detected changes in the sharpness of the glycolated (001) smectite peak. At Sites 440,435 , and to some extent at 436 they find a gradual increase in sharpness with depth of burial. This can be attributed to diagenetic processes (increasing $T$ and $P$ ) which tend to increase the crystallinity of detrital and/or authigenic smectite. At Site 434, however, Mann and Müller find frequent and significant repetition or reversals in this trend which they interpret as representing repetition of sequences by faulting. There are other possible alternatives, however, such as frequent downslope redeposition of older, originally more deeply buried sediment interbedded with other detrital material (see section on Sediment Transport and Depositional Features), or climate-induced cycles in clay mineral assemblages (see section on Biogenic Components). Slight reversals occur at Site 440 which cannot be attributed to fault repetition.

Results of smear slide and thin-section studies show that the "detrital" silt and sand fraction of middle Miocene to Recent muddy sediment at all sites consists of quartz, feldspar (predominantly plagioclase of labradorite to andesine composition), rock fragments (typically volcanic), volcanic glass, and a heavy mineral suite dominated by pyroxene (hypersthene and augite) and hornblende. The quartz/feldspar ratio is usually less than 1. This mineral assemblage is typical of those derived from volcanic arc complexes (e.g., Ingersoll and Suczek, 1979). Some of this material, along with volcanic ash, was transported to the sites by the prevailing westerlies, but most of it was probably carried in dilute suspension mud turbidites often reworked by burrowing organisms. Muddy sand and silt layers have similar mineral assemblages. Murdmaa and Kazakova (this volume), who undertook more detailed studies of the "coarse aleurite" fraction (50-100 mm) in mudstones of all Legs 56 and 57 sites, report similar results. No major trends in composition of the coarse-fraction mineralogy were found at Sites 440,441 , or 434 . This is confirmed in x-ray mineralogical studies by Mann and Müller (this 

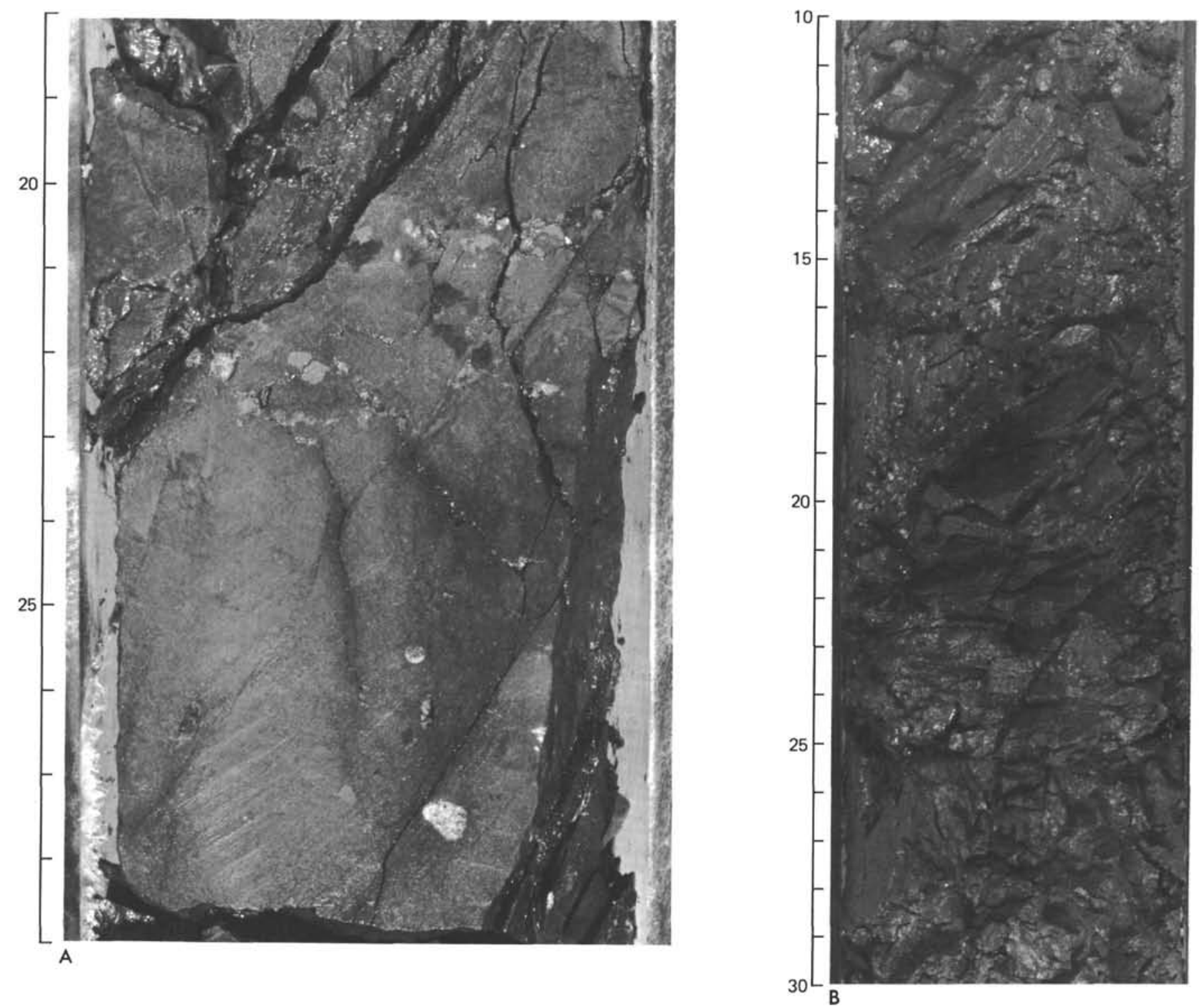

Figure 10. A. Leg 56, Sample 434B-8-1, 118-129 cm: lower Pliocene vitric diatomaceous claystone containing subrounded to subangular clasts of pumice, moderate yellow brown limestone, and grayish green vitric diatomaceous mudstone. Sediment is highly fractured; fractures are reheated. B. Leg 56, Sample 434-17-1, 10-30 cm: lower Pliocene grayish olive green diatomaceous claystone showing open hackly fracturing typical of sediment recovered at Sites 441 and 434 (see text on Tectonic Deformation of Sediment).

volume). At Site 436, however, more volcanic glass was present relative to feldspar and quartz in the coarse fraction. This suggests less transportation and reworking of detrital minerals across the trench.

The mineralogy of sand and silt layers and the coarse fraction of muds at Sites 438 and 439 , on the deep sea terrace, exhibits a time-related trend from more quartzrich and less volcanic mineral assemblages in the massive Oligocene sands and lower Miocene turbidites (Figure 14) to progressively more volcanic glass, feldspar, and volcanic rock fragments and less quartz in the upper Miocene to Pleistocene sediment (Figure 14). Murdmaa and Kazakova, Fujioka et al., and Iijima et al., all this volume, report on the composition of the Oligocene sandstones and siltstones. The sandstones are lithic arenites to lithic wackes, according to the classification of Pettijohn et al. (1972). They consist of fine-grained, subangular grains of various rock fragments, quartz, and plagioclase feldspar in order of abundance (Figure 14). Chert and silicified shale are the most abundant rock fragments in the lower part of the unit, and altered acidic volcanic rock fragments predominate in the upper part along with chert, shale, and hydrothermally altered silicic metamorphic rocks. Detrital carbonate and dolomite rock fragments are also present but minor (Figure 14). The heavy mineral suite is more typical of nonvolcanic sources, consisting of epidote, hornblende, and minor garnet, zircon, apatite, sphene, and tourmaline. Alkali feldspar predominates over plagioclase. Therefore it appears that the Oligocene shallow-water sand- 


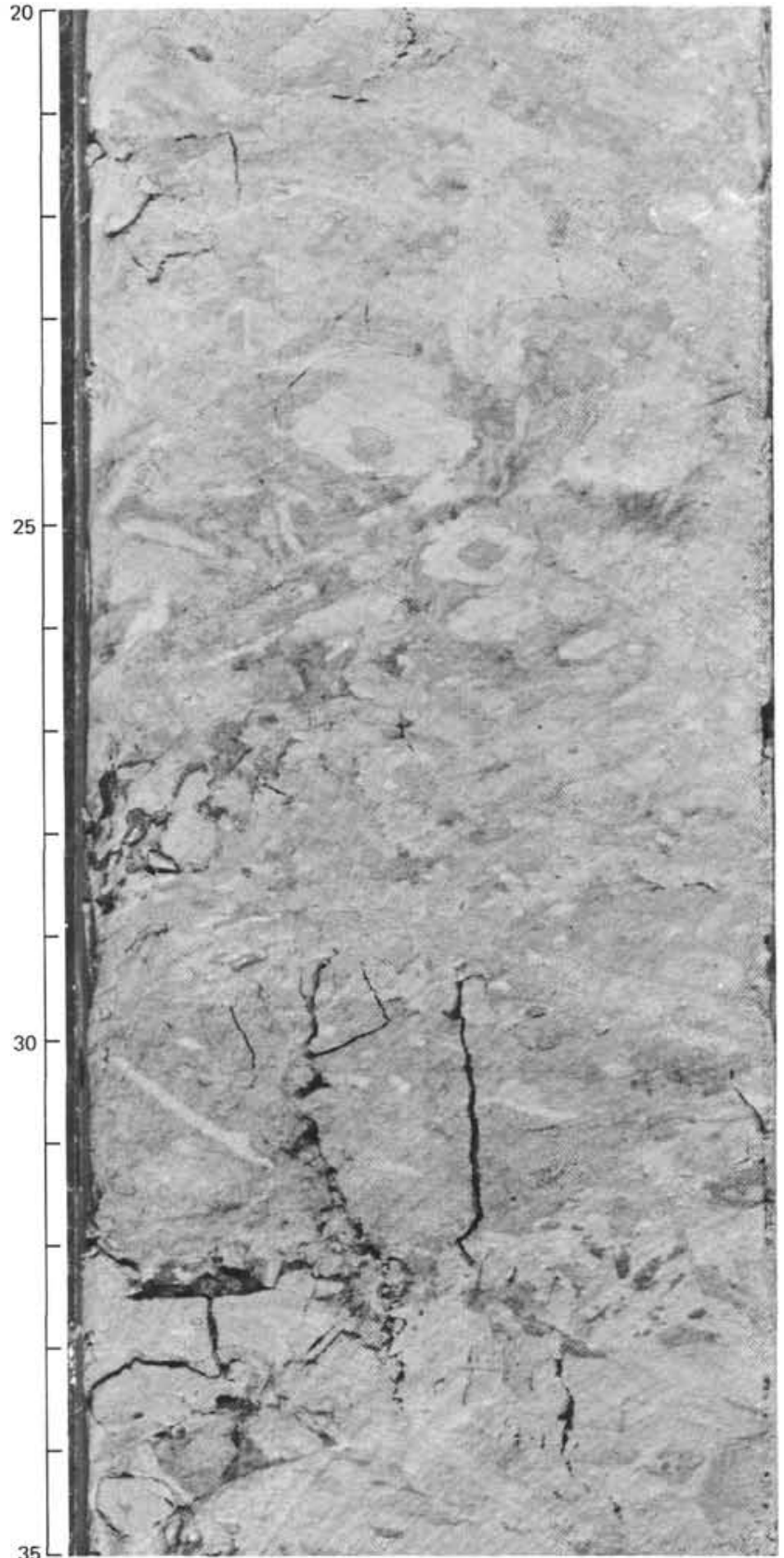

Figure 11. Leg 56, Sample 436-38-3, 20-35 cm: middle Miocene moderate yellow brown vitric radiolarian claystone; note intense bioturbation; rind burrows, fucoid-like burrows, and zoophycus are commonly found in these sediments.

stones were derived from a mixed assemblage of older sedimentary and metamorphic rocks together with altered acidic volcanic rocks. This assemblage is also found in lower Miocene turbidites but is progressively diluted by a mineral and rock fragment assemblage indicative of an active acidic (rhyolitic to andesitic) volcanic source. The latter assemblage is similar to that found in Neogene sediments of northwestern Hokkaido (Ujiie et al., 1977).

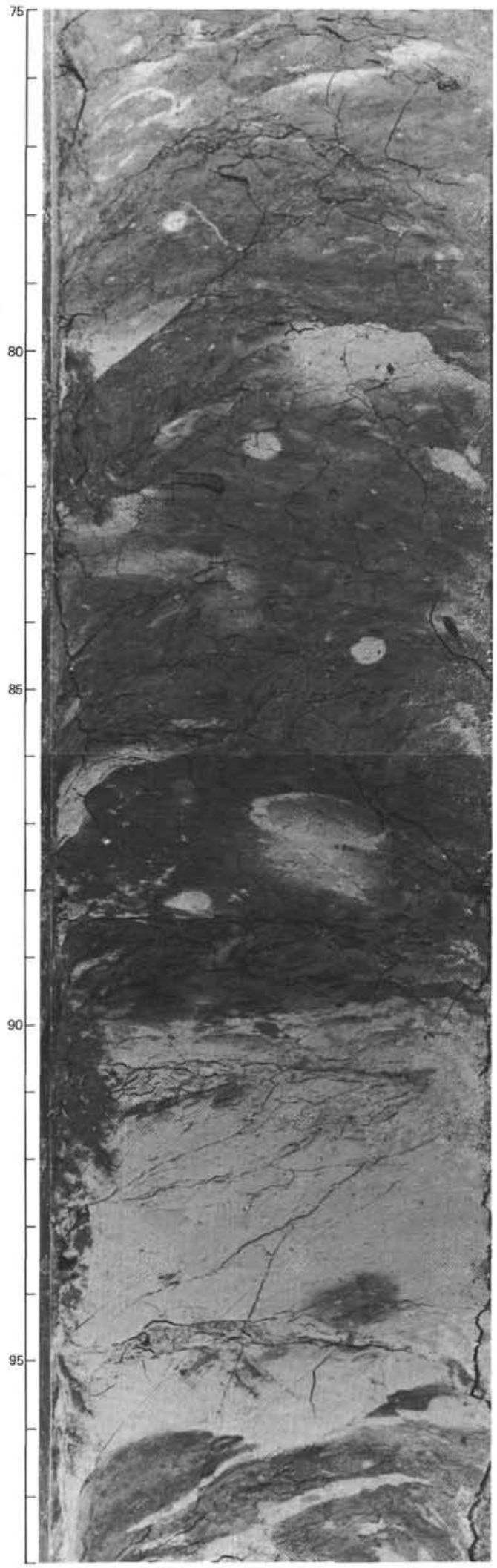

Figure 12. Leg 56, Sample 436-39-4, 75-98 cm: lower Miocene interbedded brownish black manganiferous pelagic clay and vitric radiolarian claystone (light colored) in transition from condensed Cretaceous-Paleogene pelagic sequence to Neogene hemipelagic muds. 

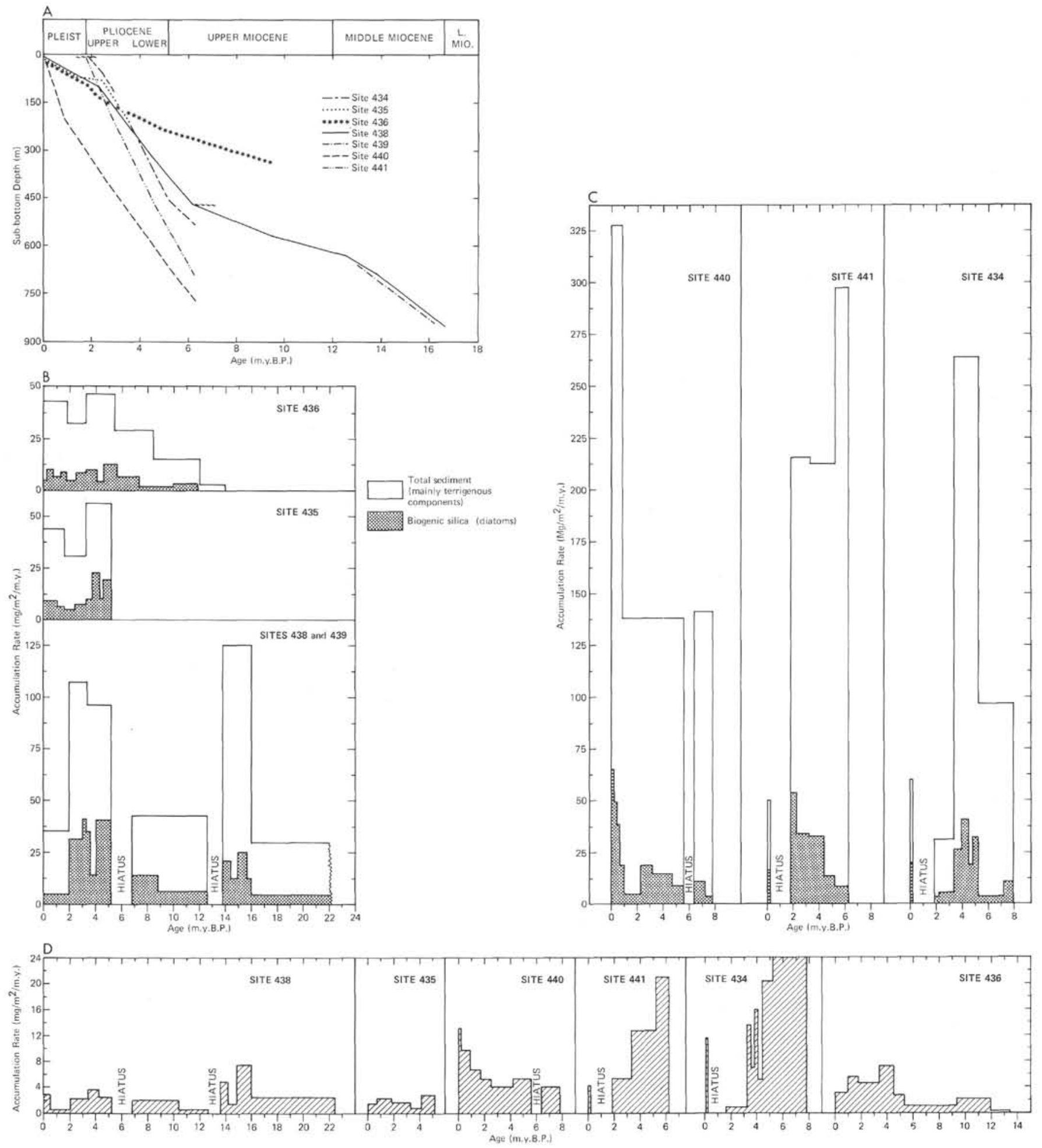

Figure 13. A. Sedimentation rates for sites on Japan Trench transect. B. Total sediment accumulation rates and rates of accumulation of biogenic silica (diatoms) through time at Sites 438,439, 435, and 436. Total sediment rate minus biogenic silica rate approximately equals flux of terrigenous clastic component (see text for details). C. Total sediment accumulation rates and rates of accumulation of biogenic silica (diatoms) through time at Sites 440, 441, and 434, on the trench inner slope (see text). D. Accumulation rates of volcanic glass at DSDP sites from Legs 56 and 57 , illustrating large variations through time and with position relative to the arc (see text for discussion). 
Most of the sediment in the Japan fore-arc region was derived, not surprisingly, from the active volcanic arc complex (existing both on Honshu and Hokkaido), with lesser contributions from exposed older nonvolcanic sedimentary and metamorphic terrain, such as those of the Kitakami Massif on northern Honshu (see Kimura, 1974; Honza et al., 1977) or the Hidaka Belt on Hokkaido (e.g., Hashimoto, 1977).

\section{Erratic Pebbles}

Erratic pebbles of various lithologies occur in the upper part of all sites, including Site 436 on the oceanic plate (Figure 15). These pebbles are found in upper lower Pliocene through Pleistocene sediment at Sites 438 and 435 and in upper Pliocene through Pleistocene sequences at Sites 440,434 , and 436 . Most pebbles recovered are rounded to subangular and less than 1 to 2 $\mathrm{cm}$ in diameter. They are usually isolated in the matrix of diatomaceous mud and are only rarely associated with sandy or silty layers, except in the upper Pleistocene at Sites 438 and 440 .

Frothy pumice pebbles are very common at all sites and may be as large as $4 \mathrm{~cm}$ in diameter. These pebbles of low density may have floated to the sites in surface currents, become waterlogged, and sunk to the sea floor.

The means of transport of other types of pebbles is more difficult to ascertain, especially when they occur isolated in thoroughly bioturbated mud. We surmise that most of them were transported by ice-rafting, and some may have slumped downslope. However, the pebbles of continental lithologies (dacite, lithic wacke, hornfelsed sandstone, and scoria) could have arrived at Site 436 only by ice-rafting. This implies that ice-rafting began in this region as early as upper lower Pliocene and certainly by the upper Pliocene.

The lithologies of pebbles present in the sites include andesite, altered dacite, gabbro, volcanic breccia, metabasalt, granodiorite, scoria, metaquartzite, gray wacke, hornfelsed sandstone, mudstone, marlstone, and tuff breccia. This is clearly a suite representing mixed metamorphic-plutonic, volcanic, and sedimentary source terrains.

\section{Biogenic Components}

\section{Calcareous Organisms}

Calcareous nannoplankton and foraminifers generally compose less than 1 to 2 per cent of the sediment at all sites but are locally abundant in some thin layers or burrow-mottled zones. Calcareous nannofossils have characteristic low diversity at all sites, are rare to few in abundance; and moderately to poorly preserved (Shaffer, this volume). Many intervals are completely barren. Planktonic foraminifers also have sporadic distribution at all sites; they are generally common to rare, except in the Pleistocene of Site 438, where they are abundant and well preserved (Keller, this volume). Planktonic foraminifers commonly occur in the upper Pliocene to Pleistocene at Site 440 but are absent or rare below that level. The distribution of zones of mottled olive gray calcareous mud rich in nannofossils is similar to that of foraminifer abundance. Sites 434 and 441 are generally barren of both planktonic foraminifers and calcareous nannofossils, indicating deposition generally at or below the calcite compensation depth (CCD). However, Shaffer (this volume) suggests that during brief periods of the late Miocene and mid-Pliocene, Site 441 may have been above the CCD. Site 436 , on the ocean plate, is barren of planktonic foraminifers, also because of its depth below the regional CCD (approx. $3500 \mathrm{~m}$ maximum) (Thompson, this volume).

The Japan Transect sites lie north and west of the present boundary between the southward-flowing cold, coastal Oyashio Current and the warm, northward flowing Kuroshio Current. Keller (this volume), Thompson (this volume), and Shaffer (this volume) have recognized periods of intensely dissolved and low-diversity assemblages of calcareous organisms interspersed with more diverse, better-preserved assemblages (warm incursions) in the Plio-Pleistocene at Sites 438, 435, and 440. These fluctuations are attributed to climatic cycles, possibly representing movements of the Oyashio/Kuroshio boundary back and forth across the sites (see Figure 20). Carbonate contents are higher in middle and upper Miocene sediments at Site 438 than in those stratigraphically above and below. The accumulation of carbonate occurred at a time when the sea floor was apparently more shallow at that site $(<1500 \mathrm{~m})$.

Benthic foraminiferal assemblages also provide some information about paleodepths at the sites. Keller (this volume) has deduced changes in the depth of the deep sea terrace sea floor at Sites 438 and 439, shown in Figure 33 and discussed in more detail later in this chapter. Site 435 , on the upper trench inner slope, seems to have been shallowing from the late Pliocene through the Pleistocene (Thompson, this volume). Sites 440,434 , and 441 were apparently always deeper than $\mathbf{2 0 0 0}$ meters, at least from the late Miocene to the present.

Reworking or redeposition of benthic foraminifers has occurred at least at Sites 440 and $\mathbf{4 3 5}$, where shallow water species are found mixed with the deeper water assemblage (Keller, Thompson, both this volume). Calcareous upper bathyal foraminifers are found also in the Pleistocene at Site 436 , on the ocean plate (Thompson, this volume). This is attributed to ice-rafting, but we cannot rule out the possibility of transport across the trench.

\section{Carbonate Diagenesis}

In continental margin sequences with high terrigenous sediment accumulation rates, such as those along the Japan fore-arc region, dilution of biogenic sediment is an important process which tends to lower the overall carbonate content. This dilution also promotes rapid dissolution of calcium carbonate in the initially undersaturated sediment pore waters. Several other factors contribute to the disappearance of carbonate from sediment. First, relatively little may be produced in the cold coastal surface waters typical of the region off northern Honshu. Secondly, high fertility along continental margin regions of upwelling, resulting in a high flux of organic carbon to the sediment/sea water interface, tends to enhance dissolution of carbonate, raising solution levels such as the lysocline and 

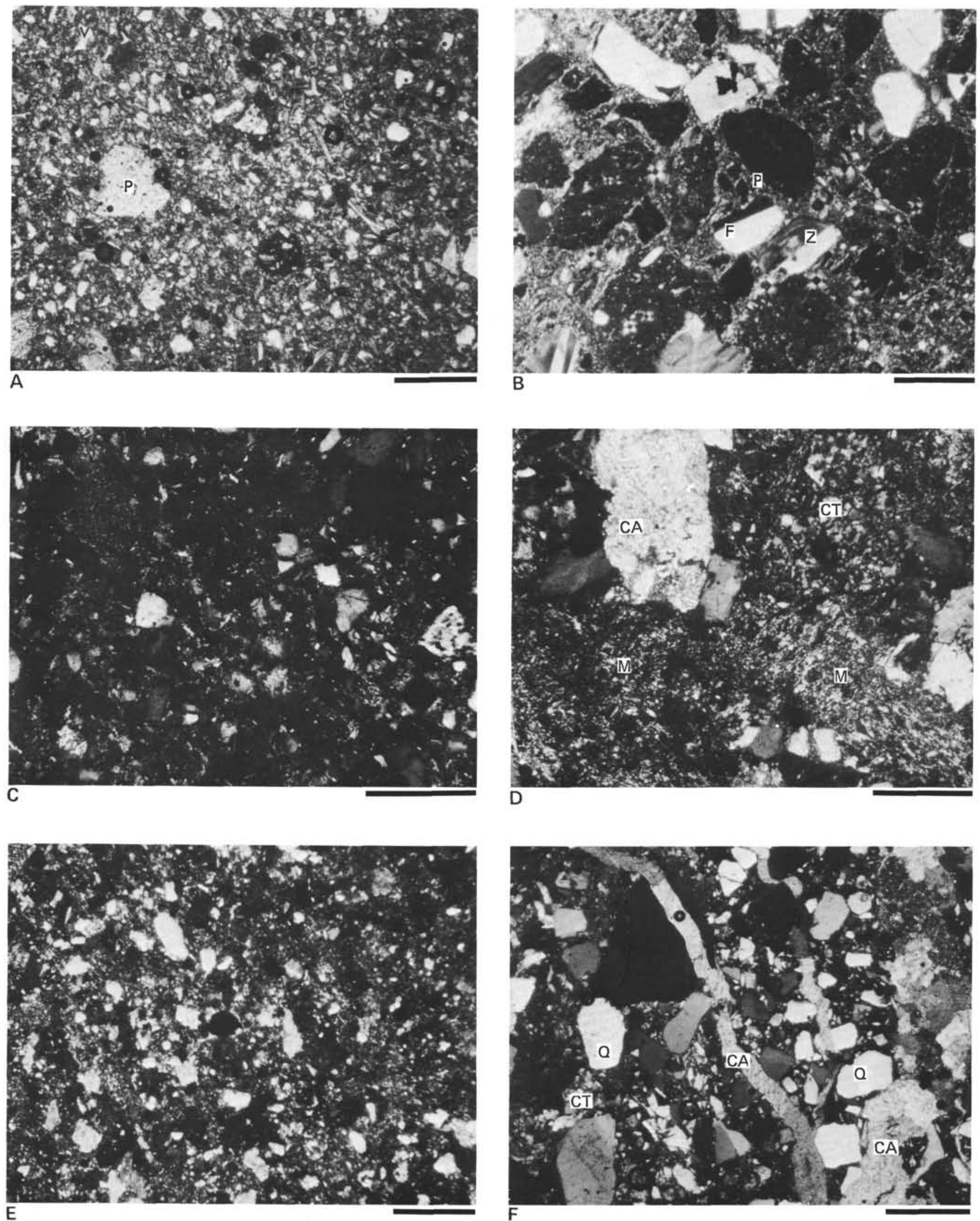
Figure 14. Thin section photomicrographs of sandstones and siltstones from Sites 438 and 439 on the deep sea terrace. A. Sample 438A-5-4, 140-143 cm (56.4 m sub-bottom): plane light (bar $=0.5 \mathrm{~mm})$. Diatomaceous silty vitric mudstone (upper Pliocene; Sub-unit $2 A$ ) consisting of angular shards of volcanic glass (V), frothy pumice (P), plagioclase feldspar, quartz, sponge spicules, and diatoms set in a clay matrix. This illustrates the predominantly acid volcanic provenance of most of the upper Neogene and Quaternary sediment in the outer fore-arc region. B. Sample 438B-9-2 $108-110 \mathrm{~cm}(901.9 \mathrm{~m}$ sub-bottom): crossed nichols (bar $=0.5 \mathrm{~mm}$ ). Muddy feldspathic vitric sandstone (lower Miocene: Unit 3) containing primarily frothy pumice grains $(\mathrm{P})$ and zoned $(\mathrm{Z})$ to unzoned $(\mathrm{F})$ plagioclase feldspar (andesine to labradorite) with a clayey, glassy matrix. This is indicative of a primarily volcanic provenance for upper lower to middle Miocene sediment. C. Sample 439-24-1, 112-119 cm (1021.6 m sub-bottom): crossed nichols $($ bar $=0.1$ $\mathrm{mm}$ ). Lithic cracks (siltstone) (Oligocene: Unit 5) in shallow marine sandstone-siltstone sequence. Contains primarily lithic fragments of mudstone, carbonate, chert, and altered volcanic rock. D. and E. Sample 439-30-3, 140-143 cm (1090.9 m sub-bottom): crossed nichols (on D bar $=0.1 \mathrm{~mm}$; E bar $=0.5 \mathrm{~mm}$ ). Lithic wacke (siltstone) (Oligocene: Unit 5) containing primarily quartz (12\%), subordinate plagioclase feldspar (6\%), and lithic fragments (82\%) of carbonate (CA), chert (CT), and mudstone (M) in a clayey calcareous matrix. This represents a primarily nonvolcanic provenance, probably the Oyashio paleolandmass. The softer mudstone lithic fragments are squeezed and resemble a clay matrix. F. Sample 439-37-1, 95-96 cm (1145 m sub-bottom): crossed nichols (bar $=0.5 \mathrm{~mm}$ ). Quartzose sandstone (Upper Cretaceous: Unit 6). Subangular to subrounded quartz (Q) (62\%), minor feldspar (<5\%), and some lithic fragments (9\%) of chert (CT) and possibly of altered volcanic rocks. The matrix consists of cryptocrystalline quartz. There are no overgrowths on quartz grains, however; this may imply an original opal cement. Veins, patches, or fracture fillings of sparry calcite (CA) are common. 


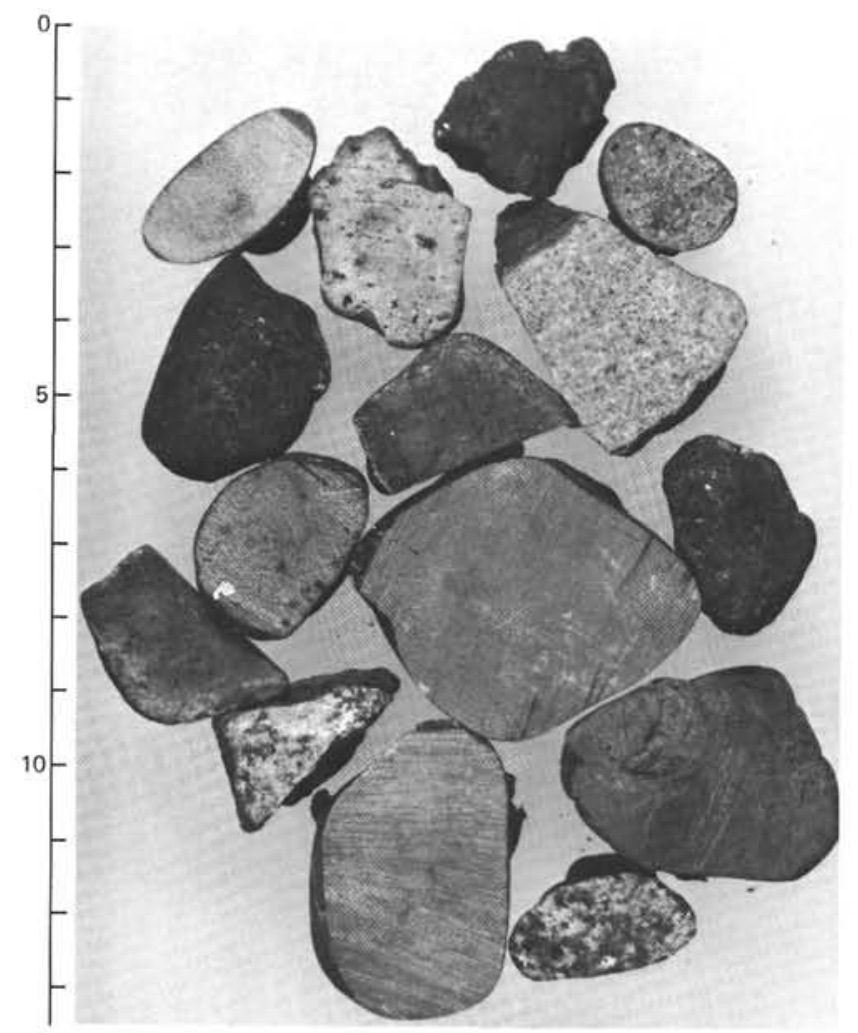

Figure 15. Example of subrounded erratic pebbles found in Pliocene-Pleistocene sediment at all sites. Pebbles are probably ice-rafted. (Quartz diorite, granodiorite, dacitic to andesitic porphyritic volcanic rocks, claystone and clayey limestone, and chert found near top at Site 440.)

CCD (which is relatively shallow in this region; Berger and Winterer, 1974), so that most carbonate produced may be rapidly dissolved before burial. Finally, diagenetic reactions in sediment, mainly because of anoxic conditions and sulfate reduction due to high rates of sedimentation and relatively high organic content, may encourage dissolution-reprecipitation of carbonate minerals.

Layers of carbonate and nodules were frequently recovered in Legs 56 and 57 sites (Figure 16). Moore and Gieskes (this volume), Matsumoto and Iijima (this volume), Mann and Müller (this volume), and Okada (this volume) have studied the mineralogy and petrography of some of these layers. Most of the layers, nodules, and diagenetic cements consist of low-magnesian calcite, but high-magnesian calcite, dolomite, ankerite, and rhodochrosite were commonly detected. Moore and Gieskes (this volume) have described the conditions of high alkalinity which prevail during formation of ammonia and sulfide, for example, in the sediments at Site 440 . This high alkalinity at relatively shallow levels and the abundant reduced iron and manganese in anoxic pore waters apparently led to precipitation of ankeritecalcite and rhodochrosite cements in some intervals as shallow as $\mathbf{2 9}$ meters at Site $\mathbf{4 4 0}$. Rhodochrosite was also detected in Miocene sediment at Site 436 (Mann and
Müller, this volume). This may have been the origin of some limestone layers and nodules as well. At Sites 438 and 439 we found a common association between limestone layers and ash or tuff beds, especially in middle to upper Miocene sediment. Petrographic examination suggests that volcanic glass has been partially dissolved and replaced by low-magnesian calcite, which also fills much of the pore space in some layers. The process of alteration is probably as described by Hein and Scholl (1978) for ash layers of late Cenozoic age in the Bering Sea. In most middle Miocene limestone beds little evidence of original volcanic material remains, but textures and sedimentary structures (e.g., Hein and Scholl, 1978) suggest to us that they are the vestiges of original pyroclastic layers. A similar origin is suggested for numerous carbonate nodules formed at Sites 434 and 441 (Okada, this volume).

\section{Biogenic Silica}

Diatoms, radiolarians, and sponge spicules, with diatoms the dominant constituent, compose the siliceous biogenic component at all sites. Locally, however, spicule-rich layers occur, and the skeleta of small sponges are common to abundant in the uppermost Miocene and the Pliocene at Sites 435 and 438 (Figure 17) and occur sporadically in the entire sequence at Site 440; they are locally abundant in upper lower Pliocene and lower Pleistocene strata at Site 440. At Sites 434, 441, and 436 , sponge skeleta are rare but disseminated spicules do occur, concentrated in places in detrital or winnowed layers. Radiolarians vary in abundance but are usually less common than either diatoms or sponge spicules. At Site 436 there is a layer of vitric radiolarian claystone ( $7 \mathrm{~m}$ thick) of middle Miocene age lying above barren manganiferous clays. Sediment older than early Miocene at Sites 438, 439, and 436 is devoid of diatom frustules but may contain reworked or unreworked Cretaceous radiolarians (e.g., Reynolds, this volume; Sakai, this volume).

The percentage abundance of diatoms and other siliceous biogenic constituents (Figure 18) is greatest in the Pliocene and Pleistocene of Sites 438, 435, and 436, where the rates of sedimentation of terrigenous detritus are relatively low (Figure 19). This is confirmed by quantitative estimates of biogenic opal-A based on $\mathrm{X}$ ray diffraction data (Mann and Müller, this volume). The abundances range from 15 to 50 and locally to 80 per cent (muddy diatomaceous ooze to diatomaceous ooze/diatomite). The sediment at Sites 440,441 , and 434 contains generally less than 25 per cent and typically less than 15 per cent diatoms. At all sites (except the short Site 435) a general decrease in diatom content downhole can be noted. Diatoms first appear in the lower middle Miocene at Site 436, on the oceanic plate, and in the lowest part of the lower Miocene at Sites 438 and 439 . They are not truly abundant before the late Miocene at these sites.

Accumulation rates of biogenic silica (diatoms) range from 0 to $65 \mathrm{Mg} / \mathrm{m}^{2} / \mathrm{m}$.y., with an average for the Neogene of all sites of about $12 \mathrm{Mg} / \mathrm{m}^{2} / \mathrm{m}$.y. (Figure 13). Sites 438,435 , and 436 , which contain very little 


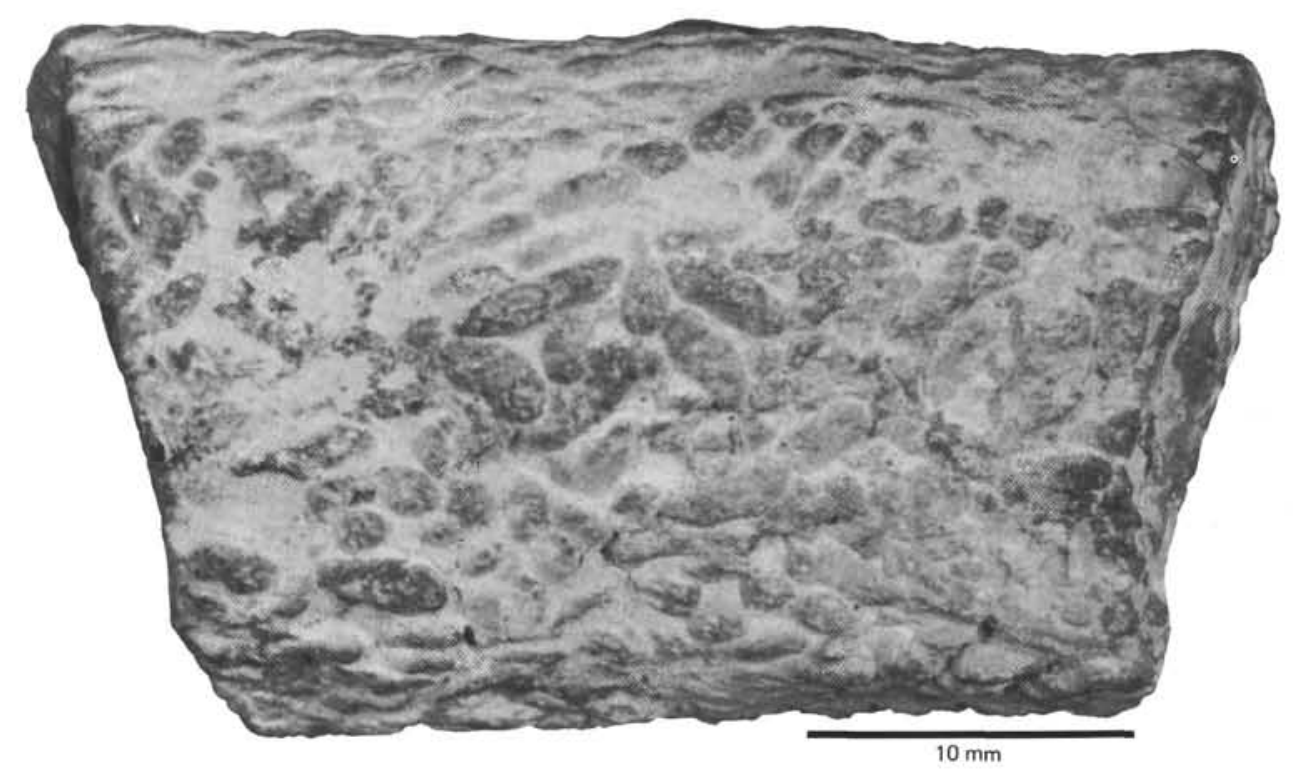

Figure 16. Leg 56, Sample 434-23-3: Calcite-cemented armored burrow. Carbonate nodules were found commonly in trench inner slope sites.

redeposited material, probably give the best picture of trends in productivity of diatom silica through time. Site 438 shows distinct high productivity episodes during the early middle Miocene (14-16 m.y.B.P.) and Pliocene (2.0-5.2 m.y.B.P.), especially during the early Pliocene. There appears to have been an increase in the late Miocene (6.8-9.0 m.y.B.P.). Pleistocene diatom accumulation rates are remarkably low. Site 435 exhibits similar trends, with a peak in accumulation rate during the early Pliocene and low rates through the Pleistocene, although not as low as at Site 438 . Site 436 shows relatively low but constant rates of accumulation on the ocean plate; there is a suggestion of an increase during the late Miocene (ca. 5.2-7.5 m.y.B.P.) from very low middle to late Miocene values, but the fluctuations in accumulation rate during the Pliocene-Pleistocene appear to be unrelated to those of other sites.

Sites 440,441 , and 434 , on the trench inner slope, have accumulation rates of diatom silica not too different from those of the other sites. This suggests an increase in the rates of terrigenous clastic input at these sites relative to diatom silica. The exception to this is the upper Pleistocene at Site 440, which has the highest rates on the transect (ca. $65 \mathrm{Mg} / \mathrm{m}^{2} / \mathrm{m}$.y.). At all other sites, Pleistocene diatom accumulation rates are low. This suggests that the increase at Site 440 is due to redeposition or reworking of diatom debris from upper slope deposits. The high rates of sediment delivery (Figure 13) at Sites 441 and 434 during the late Miocene and Pliocene apparently represent material derived from land and transported across the fore-arc region; this material diluted the diatom input rather than contributing to it, leading to low diatom percentages in the sediment (Figure 19). However, some redeposition of diatoms does occur (reworked Miocene in Pliocene at Site 441). The Pleistocene at Site 440 probably represents relatively more cannibalization of slope sediment moved downslope and trapped on the ponded midslope terrace along with a large land-derived input of sediment. There is an increase during the Pliocene in accumulation rate of diatom frustules, even at Sites 440,441 , and 434 (Figure 13). Pleistocene rates, however, cannot be discerned at Sites 441 and 434 because of a hiatus.

Thus diatom content is highest at Sites 438,435 , and 436 , where dilution by clastic debris is relatively low. Accumulation rates are similar at all sites, but some variations are apparent in the data. There is evidence for middle Miocene and Pliocene episodes of high diatom productivity. The Pleistocene was apparently marked by lowered productivity. The onset of diatom productivity occurred in the lower Miocene (Site 438), in the fore-arc region, and in the middle Miocene (Site 436), on the oceanic plate. Significantly, Site 436 was at least $1000 \mathrm{~km}$ away from the Japan margin when this occurred (see Figure 20). The onset of accumulation of diatoms in sediment at Sites 303 and 304 coincides with that at Site 436. Sites 303 and 304 were approximately $700 \mathrm{~km}$ farther east on the Pacific Plate, suggesting that diatom productivity or preservation suddenly increased at this time across the North Pacific.

\section{Preservation and Diagenesis of Biogenic Silica}

The Legs 56 and 57 sites are unusual in that diatoms are preserved to the bottom of each, even at depths exceeding 700 meters. Although some diagenesis of opaline silica (opal-A) occurs, it is not extensive (Moore and Gieskes and Iijima et al., both this volume). The stratigraphically highest occurrence of opal-CT in sediments of Site 438 was found at 700 meters (middle Miocene) by Iijima et al., whereas Moore and Gieskes found the first opal-CT lepispheres growing in the pores of diatom frustules at 850 meters sub-bottom (also middle Miocene). This early stage of diagenesis occurring at burial depths 

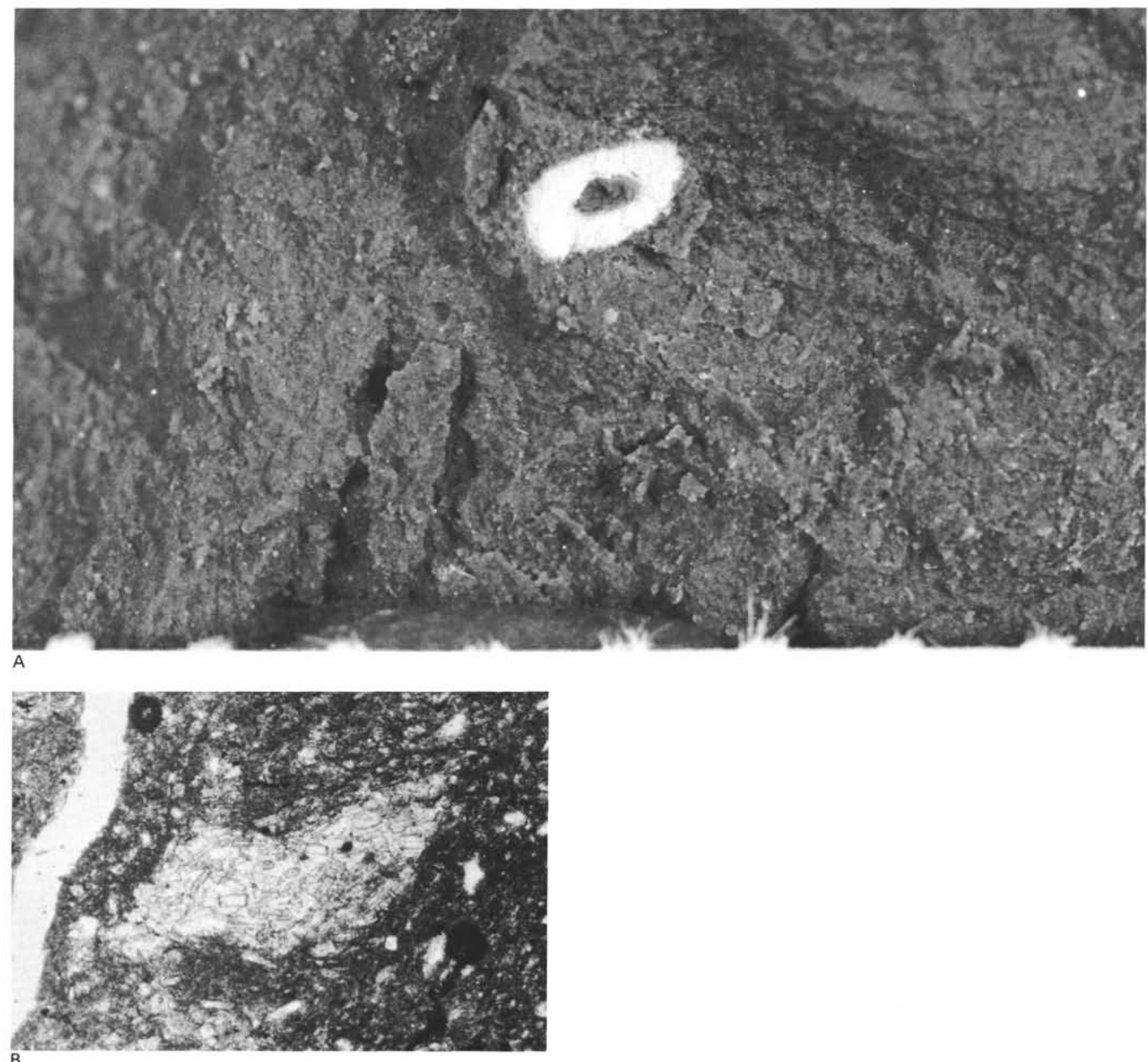

B

Figure 17. A. Siliceous sponge in diatomaceous mudstone. B. Siliceous sponge spicule accumulation in burrow mottle (Sample 434B-8-1, 120-126 cm).

over 950 meters contrasts with the extensive transformation of biogenic opal-A to opal-CT below 700 meters at DSDP sites in the Bering Sea (Hein et al., 1978). The difference is attributed to the relatively low subsurface temperatures (less than $30^{\circ} \mathrm{C}$ at $1000 \mathrm{~m}$ depth) in the Japan fore-arc region compared to those in the southern Bering Sea $\left(35^{\circ} \mathrm{C}-50^{\circ} \mathrm{C}\right.$ as shallow as $\left.600 \mathrm{~m}\right)$ and provides evidence that the paleogeothermal gradient off Japan was low, at least during the Neogene.

However, diatom dissolution and possibly formation of inorganic opal- $\mathbf{A}^{\prime}$ is not precluded, even at fairly shallow depth in the sediment. Diatoms are the most susceptible to dissolution of any biogenic siliceous material (see review by Hein et al., 1978), and it is estimated that less than 1 per cent of those produced in surface waters are preserved in sediment. Preservation of diatoms is generally poor below 500 to 600 meters at all sites (see Barron, Harper, both this volume), and diatoms are rare, for example, below 700 meters at Site 440, but both preservation and abundance (Figure 19) are variable throughout each site. Sediment below 500 meters subbuttom (middle to upper Miocene) at Site 438 appears to be partly lithified by silica cementation. Diatoms are relatively poorly preserved below 500 meters as well. Thus there is evidence for dissolution and possibly for silica reprecipitation (as inorganic opal-A') at shallower levels in some sites. Further detailed study of such trends is necessary. 


\section{VOLCANIC COMPONENTS}

\section{Sedimentation and Composition}

Volcanic glass, feldspar, and volcanic rock fragments occur in varying proportions throughout the sedimentary sequence at all sites on the deep sea terrace, trench inner slope, and oceanic plate. When recovery of coherent core pieces allows, discrete volcanic ash layers (Figure 21) can also be observed at all sites. Most of the volcanic material, however, occurs disseminated throughout the sediment, concentrated in burrow mottles or patches, or in layers of redeposited sediment, including turbidites. Pebbles of pumice are also common; these occur isolated in the sediment and are not obviously associated with either layers of ash or redeposited clastic layers.

Volcanic glass usually occurs in the form of clear strands with relatively low refractive index (1.45-1.53). Its chemical composition is highly silicic (Fujioka et al., this volume) and is indicative of rhyolitic to rhyodacitic volcanism. Volcanic rock fragments typically consist of microlitic plagioclase feldspar set in a dark glassy matrix; quartz and sanadine are also constituents of some fragments. Plagioclase feldspar occurs also as angular to subangular grains in both ash layers and disseminated in diatomaceous muds. The composition of the plagioclase feldspar ranges from $\mathrm{Ab}_{80} \mathrm{An}_{20}$ to $A b_{50} A_{50}$. Many plagioclases are zoned. Feldspar usually predominates over quartz in the sediment.

Many graded ash layers are contaminated by significant amounts of other components, including diatoms, sponge spicules, clay minerals, quartz, and other terrigenous grains. Textural grading occurs in relatively pure volcanic ash layers (Figure 21), probably resulting from slow settling through the water column after an airfall event. However, when contamination exceeds about 25 per cent, there is a possibility that the ash has been redeposited. Of course contamination can also be introduced by burrowing organisms.

Ash layers range from $0.2 \mathrm{~cm}$ to over $12 \mathrm{~cm}$ thick, averaging about $2 \mathrm{~cm}$. The thickness seems to vary with distance from land such that the ash layers are typically less than 1 to $2 \mathrm{~cm}$ thick at Site 436 , on the oceanic plate, and are usually greater than 3 to $5 \mathrm{~cm}$ thick at Site 438, nearest the Japanese landmass. Many of the ash layers are texturally graded and range in grain size from fine sand to fine silt. The ash layers at Site 436 consist of silt and fine silt-sized components. There appears to be a slight trend toward increasing median grain size and ash layer thickness with progressively young age at Site 436 (Furuta and Arai, this volume). This may be the effect of the movement, through time, of Site 436 toward the Japanese landmass. Much of the volcanic glass contained in the mudstones from Sites 434 and 441 on the trench inner slope may have been reworked and redeposited from upslope as the following discussion will indicate.

\section{Trends in Explosive Volcanism and Ash Deposition}

The record of explosive volcanic activity in the arc on Honshu can be read in the distribution of volcanic ash layers at the sites which were stationary relative to the arc. Some of this record is undoubtedly distorted because of incomplete core recovery, disturbance of sediment during drilling, and by natural disturbance mechanisms such as bioturbation or slumping-erosion on the slope. Sites 438 and 440 offer the best opportunity to study the record of volcanism because core recovery was good and sedimentation rates relatively high, thus inhibiting the efficiency of bioturbation. The occurrence of ash layers (number of layers per $10 \mathrm{~m}$ of sediment) together with amounts of background volcanic ash determined by study of smear slides is shown on Figure 22 . Cadet and Fujioka (this volume) have plotted the number of ash layers per million years, making a correction for incomplete core recovery (Figure 23). This plot shows a similar pattern for both Sites 438 and 440 for the last $6 \mathrm{~m} . \mathrm{y}$. or so (the limit of the Site 440 record), with a peak in ash layer frequency during the Pliocene (about 3 m.y.B.P.) declining to a low at the Pliocene/Pleistocene boundary and apparently increasing again during the late Pleistocene. The pattern at Site 438 also extends back to the lower Miocene with a low in the upper Miocene, a slight increase in the middle Miocene, and a peak near the lower to middle Miocene smaller than that in the Pliocene. Thus it appears from the ash layer frequency that explosive volcanism on Honshu to the west of the drill site reached a peak in the early middle Miocene and mid-Pliocene, with little or no explosive volcanism occurring in the middle to late Miocene and a decline during the late Pliocene-early Pleistocene. We emphasize that this represents only the record of explosive, silicic volcanism carried to the sites by the prevailing westerlies. Some caution in interpretation must be used, because we do not yet know the full extent of climate-induced fluctuations in zonal wind boundaries and wind velocities which might have influenced transport of volcanic ash during the Neogene. However, the patterns of ash layer frequency are similar to those in other circum-Pacific regions (Kennett and Thunell, 1975, 1976; Kennett et al., 1977; summarized by Kenrett, in press). The record at Site 436 exhibits the same general pattern as at Sites 438 and 440 , complicated by the progressive change in position of the site as it approaches the Japan landmass (e.g., Furuta and Arai, this volume).

Patterns in the concentrations and accumulation rates of volcanic glass in sediments should show about the same peaks as in ash layer frequency (e.g., Donnelly, 1975). Ideally the disseminated glass should give an even better picture of explosive volcanism than ash layers owing to the problems of bioturbation and nonrecovery in the latter. Figure 13 and Table 2 show the concentrations of volcanic glass (Figure 22) corrected to accumulation rates. An illustration of the benefit of calculating the concentration (ignoring individual ash layers) as accumulation rates is shown, for example, by the pattern at Site 436. The overall background concentration of glass at Site 436 is the highest of any of the sites, averaging from 10 to 15 per cent. A general increase in concentration with superimposed peaks can be seen from the middle Miocene to the lowermost Pleis- 

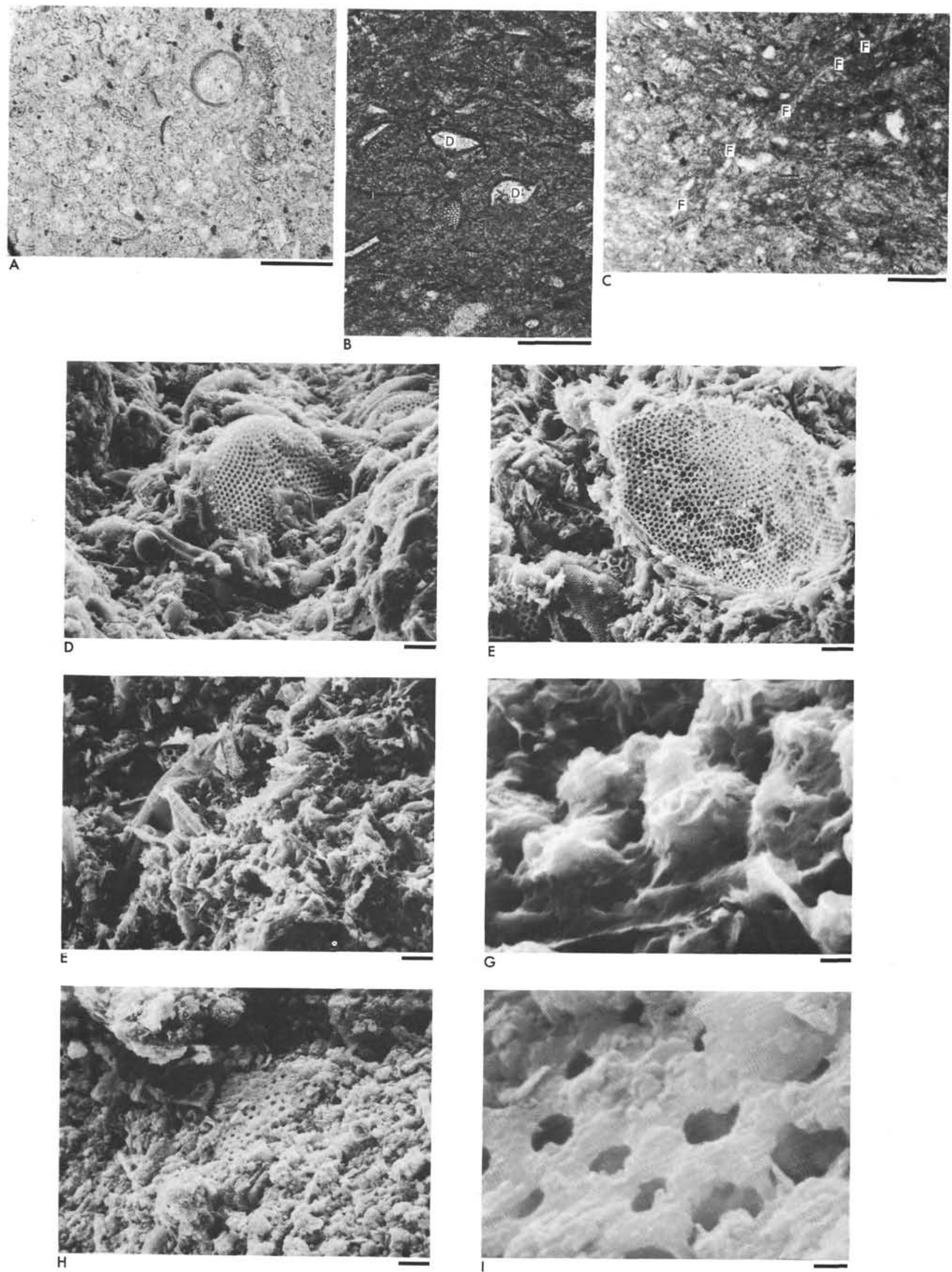
Figure 18. Thin section and SEM photomicrographs of diatomaceous mudstones. A. Sample 440-1-3, 148-150 $\mathrm{cm}:(4.5 \mathrm{~m}$ sub-bottom) plate light (bar $=0.1 \mathrm{~mm})$. Open and primarily randomly oriented framework of well-preserved diatom frustules in vitric diatom mudstone. Diatom frustules are virtually swirled and upended by burrowing organisms. Such a fabric inhibits compaction and leads to underconsolidation at shallow burial depths (e.g., Bryant et al., this volume). B. Sample 438B-26-6, $140 \mathrm{~cm}:$ (305.5 $\mathrm{m}$ sub-bottom) plane light; section perpendicular to bedding $($ bar $=0.1 \mathrm{~mm})$. Beginning of compaction of diatomaceous claystone. Note that diatoms with vertical orientation (D) are partly collapsed, and the majority of diatoms are oriented in the plane of the bedding. C. Sample 434B-7-1, 35-40 cm: (343.4 m sub-bottom) plane light; section perpendicular to bedding (bar $=0.5 \mathrm{~mm})$. Preferred orientation of diatoms in plane of bedding in fractured diatomaceous mudstone. Fracture $(\mathrm{F})$ is oriented oblique to bedding and causes slight reorientation of elongate particles near the fraction plane. D. Site 440 (Core 1):(4 m sub-bottom) SEM, bar $=10 \mu \mathrm{m}$; Typical diatomaceous mudstone (Quaternary) with well-preserved diatom frustules randomly oriented. E. Site 438 (Core 84):(851 m sub-bottom) SEM, bar = 10 $\mu$ m. Compact diatomaceous mudstone (middle Miocene) with partly dissolved diatom frustules. Contrast with D. F. Site 438 (Core 84):(851 m sub-bottom) SEM, bar $=10 \mu \mathrm{m}$. Same as $\mathrm{E}$ (perpendicular to bedding) showing fabric, which remains somewhat unoriented even after at least 850 meters of burial. G. Site 438 (Core 84):(851 m sub-bottom) SEM, bar $=1 \mu \mathrm{m}$. Poorly formed silica (opal CT) overgrowths formed on portion of diatom frustule (see Moore and Gieskes, this volume). H. Site 440 (Core 67):(721 m sub-bottom) SEM, bar = $10 \mu \mathrm{m}$. (lower Pliocene-upper Miocene); note the poor preservation and overgrown appearance of diatom frustules (see I) and clay mineral aggregates. I. Same as $\mathrm{H}$ : bar $=1 \mu \mathrm{m}$. Detail of dissolved and partly overgrown diatom test. 


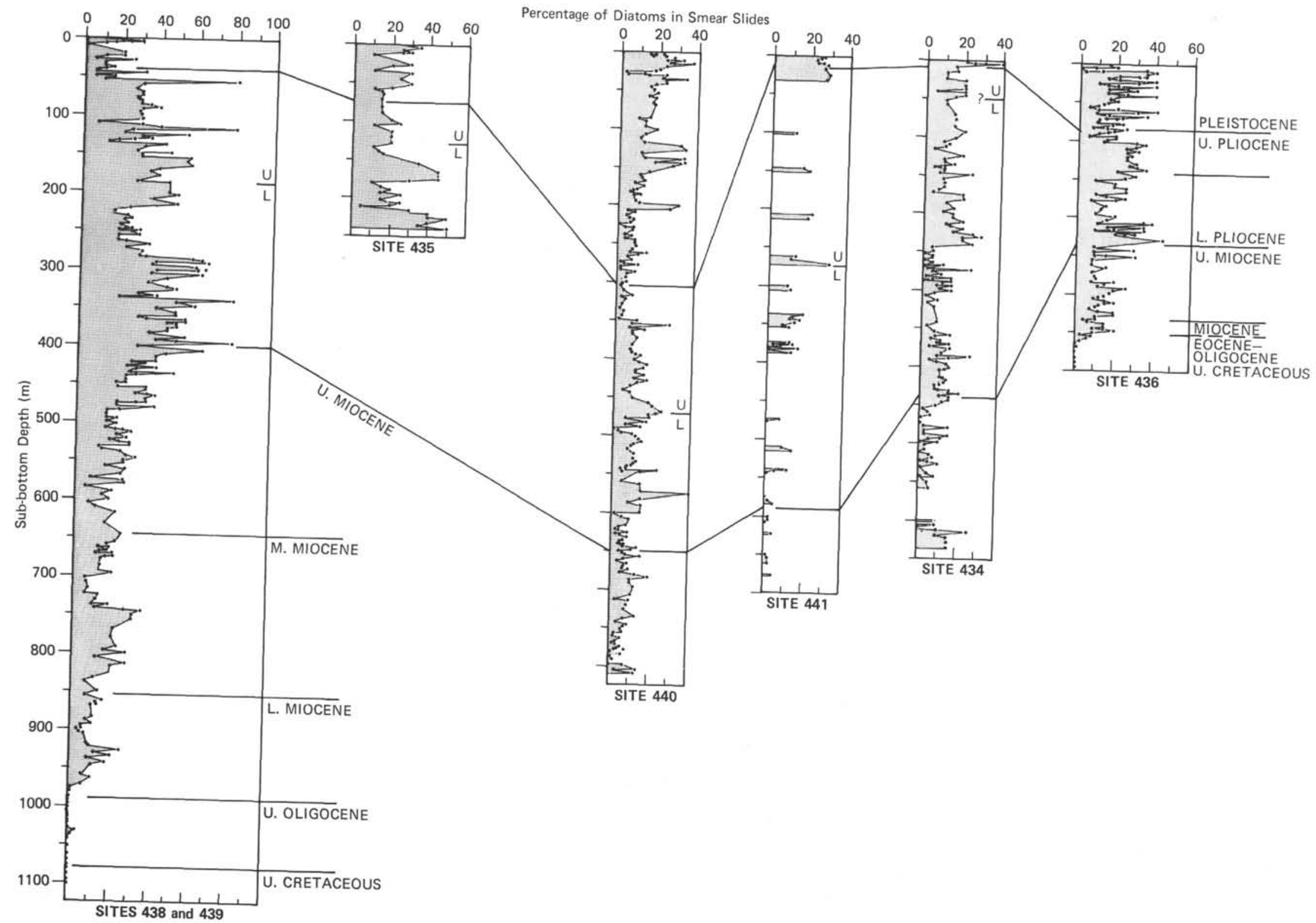

Figure 19. Percentage of diatoms in smear slides at all DSDP sites, Legs 56 and 57. Note generally higher values in sites on deep sea terrace (Sites
438 and 439), upper slope (Site 435), and on the oceanic plate (Site 436). 


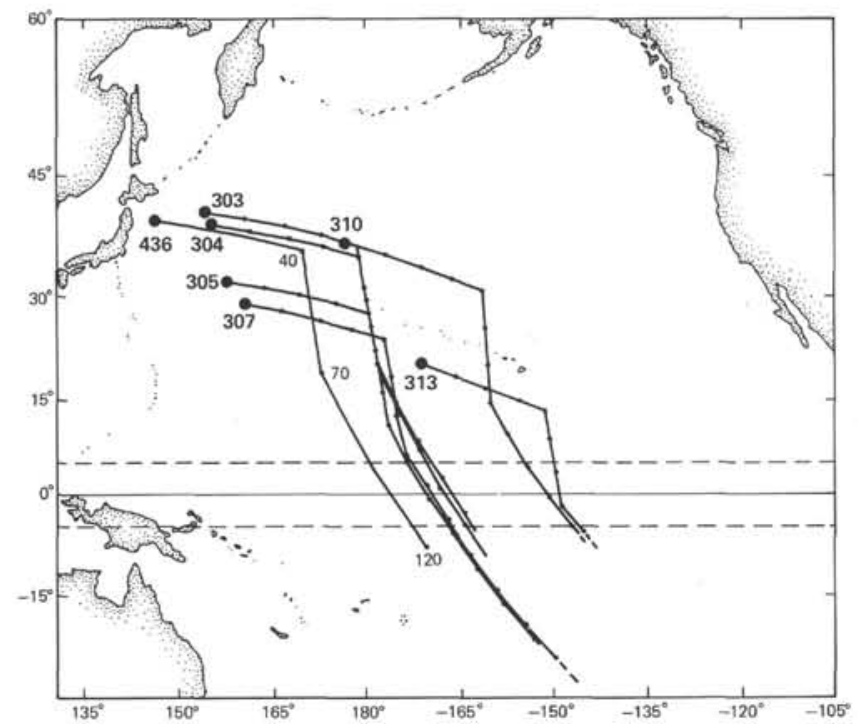

Figure 20. Backtracking of DSDP sites in the western Pacific (modified from Lancelot and Larson, 1975), showing the convergence of Site 436 with the Japan continental margin beginning at about 40 m.y.B.P.

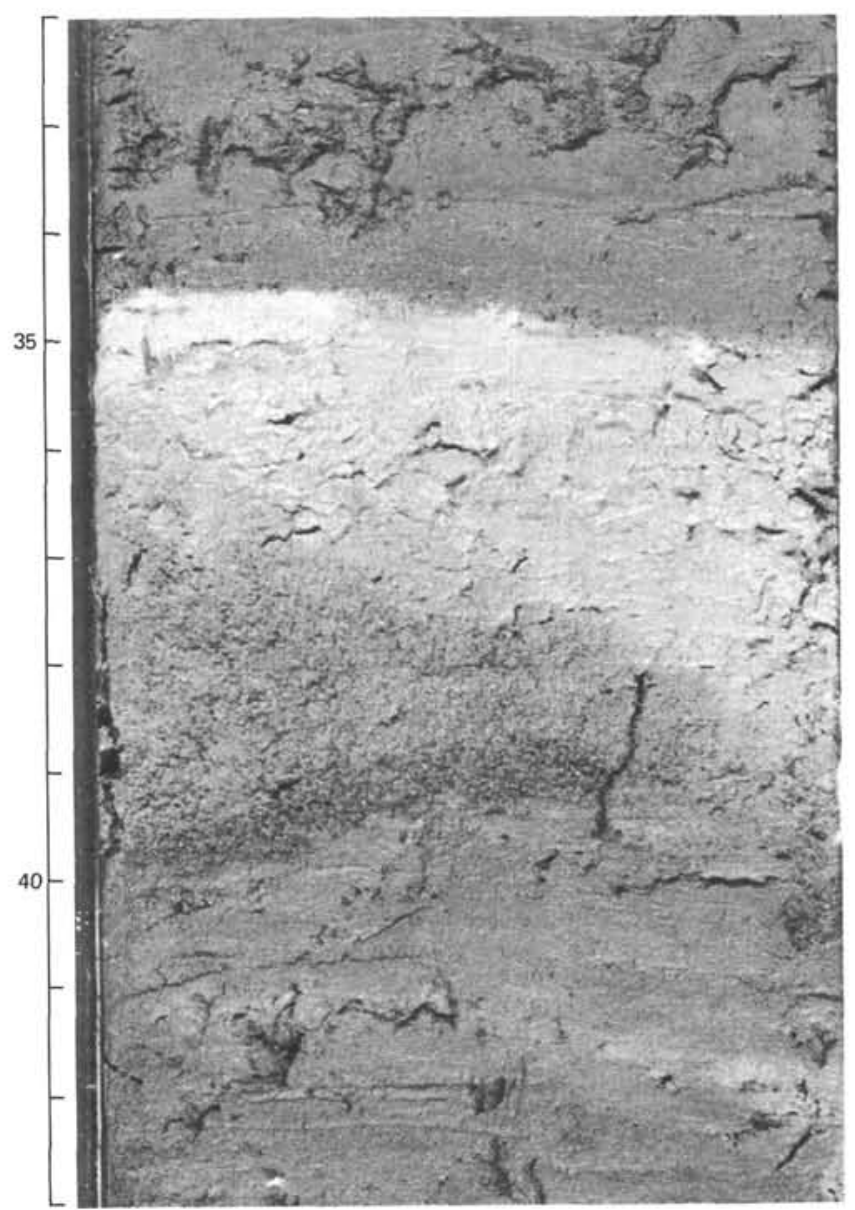

Figure 21. Leg 56, Sample 435A-3-4, 32-43 cm: lower Pliocene graded volcanic ash layer about $5 \mathrm{~cm}$ thick. This is typical of most coherent ash layers recovered at sites from Legs 56 and 57. tocene; concentrations are relatively low in Pleistocene sediment. The pattern of concentration is similar to that of ash layer frequency. An abrupt decrease in explosive volcanism is apparent in the Pleistocene, even though the site is at its nearest point to the landmass. Even though the concentrations of volcanic glass are the highest of any site, the rate of accumulation is lower than that at Sites 440,434 , and 441 . Surprisingly, however, the rate of accumulation is consistently higher than at Sites 438 and 435 , which are much closer to the landmass (0-6 m.y.B.P.). From about 6 to 12 m.y.B.P. the accumulation rate of volcanic glass is the same at Sites 436 and 438. This implies that the amount of ash from atmospheric fallout reaching the ocean plate, even as far back as about 12 m.y.B.P., when the plate was more than $1000 \mathrm{~km}$ away from the Japanese arc, was the same as or greater than that reaching the outer part of the deep sea terrace. Another possibility is that bioturbation was less effective at Site 438 because of higher rates of sedimentation and because most ash is concentrated in discrete layers rather than disseminated. These calculations of course are dependent on an adequate biostratigraphic and absolute age framework for each site and on the assumption that smear slide estimates of volcanic glass are accurate or at least consistent from one site to another and that sampling is not biased.

The accumulation rates of glass at Sites 438 and 439 during the Miocene are also interesting since they indicate rates relatively higher than those during the Pliocene peak episode in ash layer frequency at the same site. Cadet and Fujioka (this volume) comment on the apparent disparity between the curves representing intensity of explosive volcanism constructed from the DSDP sites and calculation of the volumes of material erupted on land for various time intervals (e.g. Sugimura et al., 1963; Horikoshi, 1976). A major eruptive episode on Japan occurred during the late Oligocene-early Miocene; the volcanic products were mainly basaltic. For this reason, the ash layer record may not reflect the intensity of this episode, since basaltic volcanism is generally not explosive. However, volcanic material did reach Sites 438 and 439 in substantial amounts during the 22 to 14 m.y.B.P. interval, as shown by the curve of accumulation rates (Figure 13).

One further aspect of sedimentation suggested by volcanic glass accumulation rates is that of redeposition of volcanic detritus or direct transport from land areas by turbidity currents flowing down channel systems. The highest rates of accumulation of volcanic glass at any site occur in the Pleistocene at Site 440 and the upper Miocene and Pliocene at Sites 434 and 441, which had very similar rates of accumulation. The high rate of accumulation at Site 440 occurs in the "ponded" interval of high total sediment accumulation rates (Figure 13). The values increase steadily from the late Pliocene through the Pleistocene. Much of the sediment in this interval has a higher proportion of silt and sand than at other sites, and a number of graded volcaniclastic sand and silt layers occur as well. The anomalously high rates of accumulation of volcanic glass (up to four times that of Pleistocene intervals at any other site) are probably 


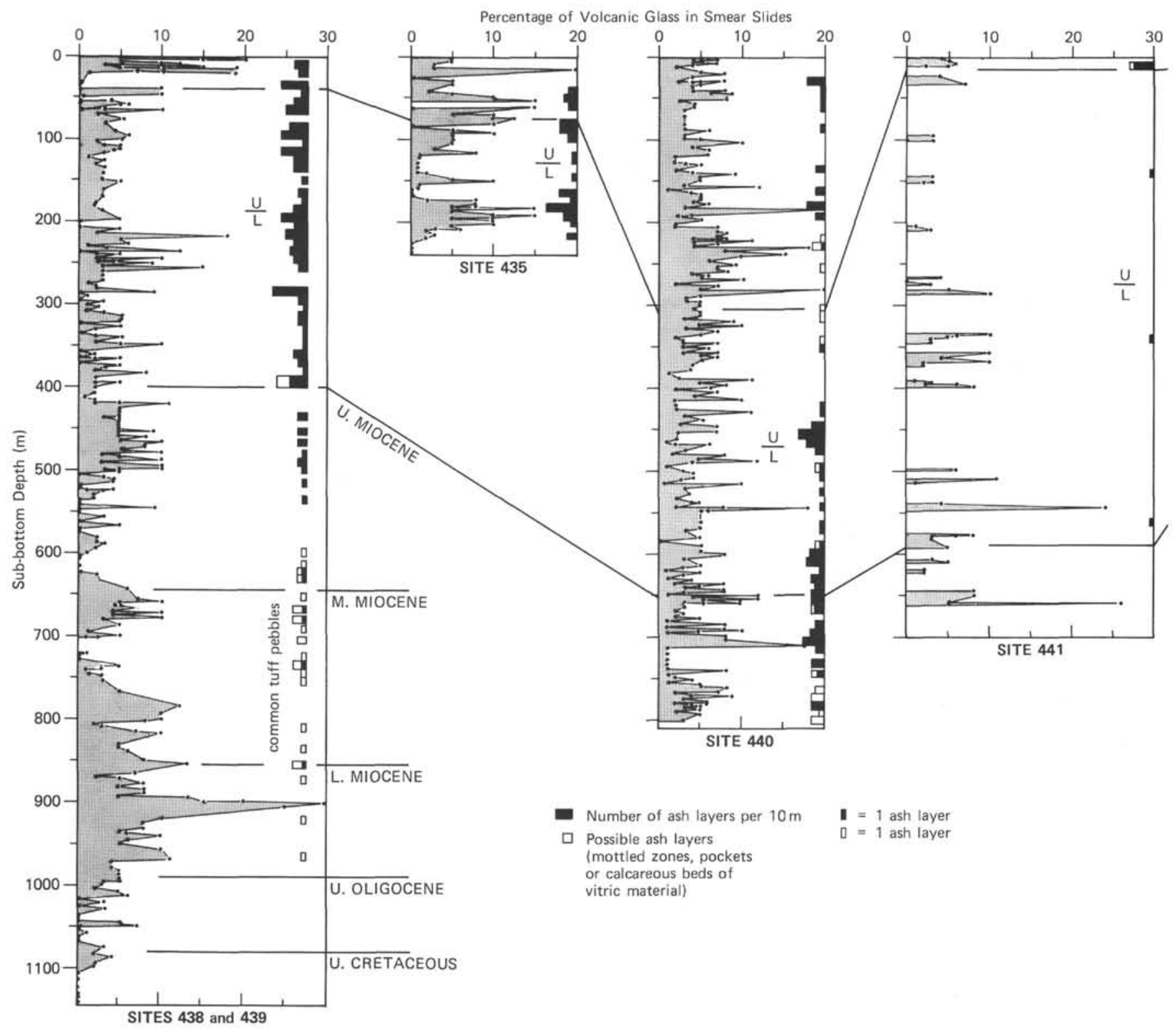

Figure 22. Percentage of volcanic glass in smear slides at all DSDP sites, Legs 56 and 57 (see text), and frequency of ash layers per core.

due to deposition of reworked volcanic material. The pattern of rates of accumulation of organic matter, primarily from terrigenous sources, are similar.

Sites 434 and 441 probably also received large amounts of resedimented volcanic material during the late Miocene and Pliocene, again at rates from two to four times that at any other site during the same period. The volcanic glass did not occur, however, in discrete sand or silt layers but was deposited together with large volumes of mud. Therefore one must be careful in interpreting either the concentration or rates of accumulation of volcanic detritus. At sites largely out of the path of major influxes of clastic detritus, the accumulation rates of volcanic glass mirror the pattern of volcanism indicated by ash layer frequency. The accumulation rates of disseminated volcanic ash may be more indica- tive of times of volcanic events on the adjacent landmass, as illustrated by the lower Miocene at Sites 438 and 439.

\section{Diagenesis}

Another factor that modifies the record of volcanism in sediments is the diagenesis of volcanic glass (e.g., Hein and Scholl, 1978). This is not a significant problem at most Legs 56 and 57 sites, primarily because of the low geothermal gradients $\left(1^{\circ}-3^{\circ} \mathrm{C} / 100 \mathrm{~m}\right)$ encountered in the fore-arc region. At present, the maximum temperature of the sediments at 1200 meters depth is about $30^{\circ} \mathrm{C}$. Although it is not entirely clear that this is the maximum temperature achieved in the sediments during the Neogene, various studies of organic matter maturation (see Whelan and Sato, this volume, and following 


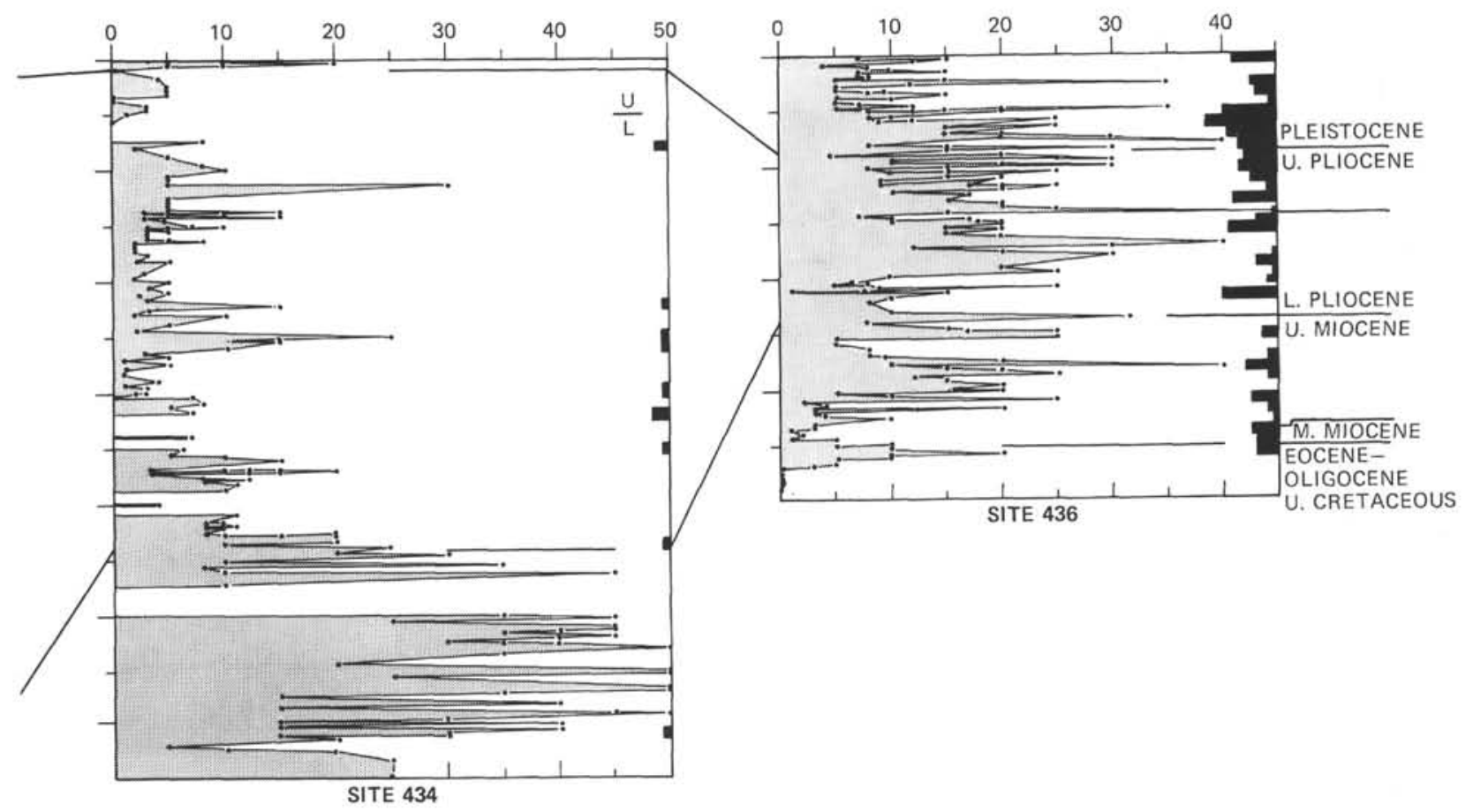

Figure 22. (Continued.)

section, this chapter) and of silica diagenesis (Iijima et al., this volume) suggest that this is the case. The shallowest occurrence of opal-CT, the first stage of solution and remineralization of glass and diatom frustules, was observed at about 700 meters sub-bottom at Site 438. Clinoptilolite, a zeolite resulting from alteration of glassy material, was first observed at about 935 meters (lower Miocene) at Site 439 (Iijima et al., this volume). However, glassy material was found in sediment to a depth of 1063 meters. Below this, the Oligocene sandstones contain altered tuffaceous clasts containing the zeolite analcime. Diagenesis, therefore, has affected mainly the record of volcanic glass accumulation in lower Miocene and possibly middle Miocene sediments.

Some individual ash layers have also become cemented by calcite and $\mathrm{Mg}$-calcite (e.g., Matsumoto and Ii- jima, this volume) in anoxic sediments. Thus the ash layers may now be represented by a thin limestone layer (e.g., samples 438A-33-3 and 438A-35-3) (Figure 24). This again will modify ash layer frequency curves of the type shown by Cadet and Fujioka (this volume). Possible original ash layers of this type are included in the tabulation of Figure 22 and increase the size of the peak for the middle Miocene.

\section{Sedimentation and Diagnesis of Organic Matter}

\section{Accumulation Rates and Sources}

The average organic carbon content of sediment deposited on the deep sea terrace and trench inner slope is about $0.6 \mathrm{wt}$. per cent. The maximum measured organic carbon value is $2.22 \mathrm{wt}$. per cent and the minimum is $0.2 \mathrm{wt}$. per cent in mudstone and less than $0.1 \mathrm{wt}$. per 


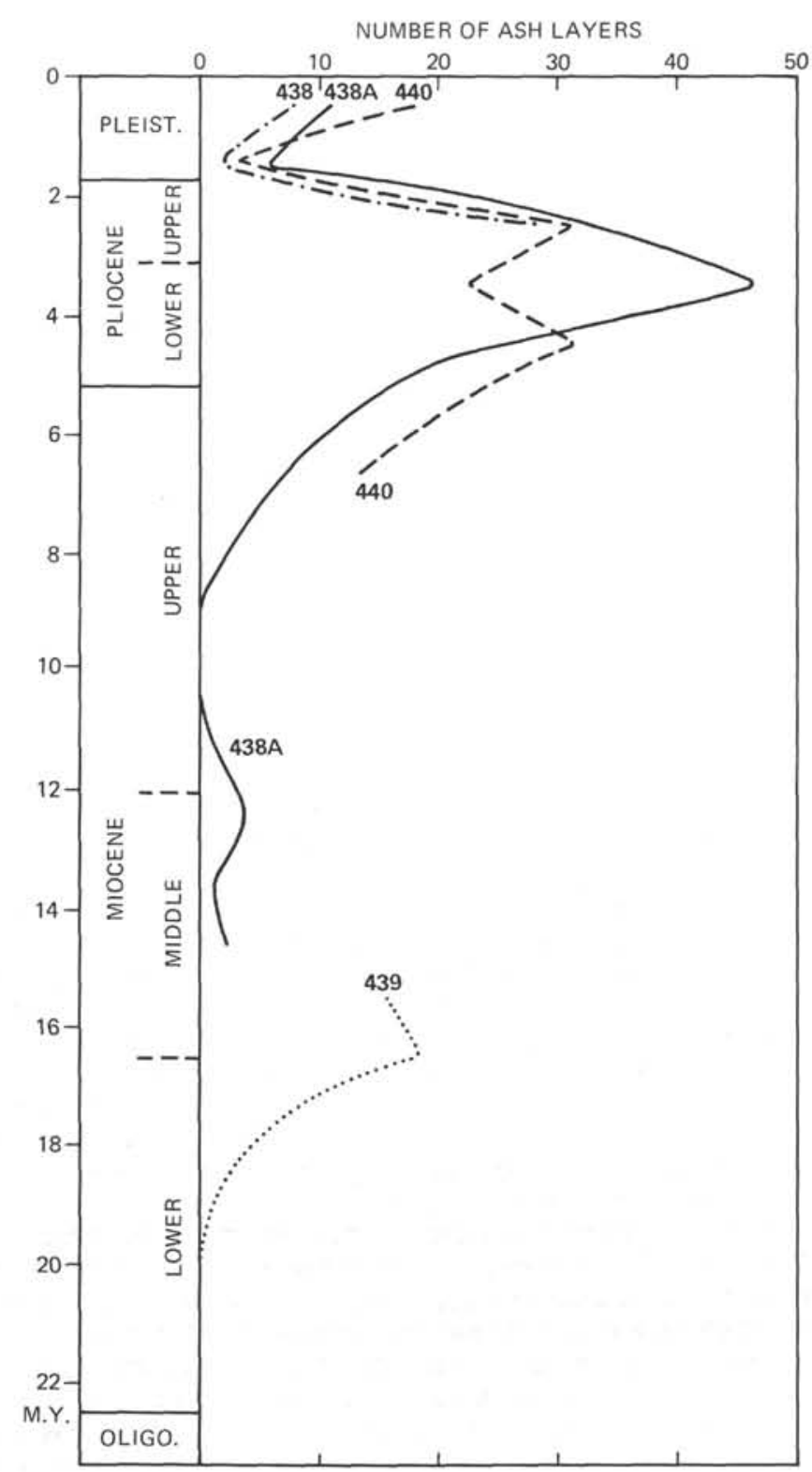

Figure 23. Frequency of ash layers (per m.y.) at Sites 438,439 , and 440, corrected for recovery (see also Figure 22, after Cadet and Fujioka, this volume).

cent in the upper Oligocene sandstones and conglomerates at Site 439. The trends of organic carbon with depth and age at Legs 56 and 57 sites are shown in Figure 25.

In general, the highest organic carbon contents are found in the Pleistocene and Pliocene sediments, and values generally decline slightly downhole in all sites. However, the organic carbon contents are surprisingly uniform and high. The sediment at Site 436, on oceanic crust, exhibits progressively lower values with increasing age, ranging from a high of $0.75 \mathrm{wt}$. per cent in the upper Pleistocene to a low of less than $0.1 \mathrm{wt}$. per cent in Miocene and older sediment. This is probably a direct reflection of the transit of this site, caused by convergence of the oceanic plate with the Japan Trench, from a position under an infertile central gyre region to its present position near a very fertile and productive gyre margin. Thompson and Whelan (this volume) have discussed this aspect relative to the increased occurrence with progressively young age of intact faecal pellets in sediment at Site 436 . In a similar manner the translation of Site 436 toward the Japanese landmass has also increased the rate of accumulation of biosiliceous material (Figure 13) and volcanic ash (Figure 13 and Furuta and Arai, this volume). The accumulation rate of organic carbon at Site 436 (Table 2) was less than $0.04 \mathrm{Mg} / \mathrm{m}^{2} / \mathrm{m}$.y. $\left(0.0410^{-3} \mathrm{~g} / \mathrm{cm}^{2} / \mathrm{y}.\right)$ in late Miocene and older sediments and increased to a maximum of $0.24 \mathrm{Mg} / \mathrm{m}^{2} / \mathrm{m} . \mathrm{y} \cdot(0.24$ $10^{-3} \mathrm{~g} / \mathrm{cm}^{2} / \mathrm{y}$.) during the Pleistocene as the site neared the Japan margin. Sites 440 and 438 offer a good record of the rate of organic carbon accumulation on the trench inner slope and deep sea terrace. Site 438, which has a generally lower total sediment accumulation rate than Site 440 (Figure 13, Table 2), also has a much lower rate of accumulation of organic carbon, ranging from a low of $0.15 \mathrm{Mg} / \mathrm{m}^{2} / \mathrm{m} . \mathrm{y}$. in the middle Miocene to a high of $0.87 \mathrm{Mg} / \mathrm{m}^{2} / \mathrm{m} . \mathrm{y}$. in the late Pliocene, with a decrease in the Pleistocene. At Site 440 the accumulation rates of organic carbon are from two to four times those at Site 438 for equivalent intervals of time. These values range from $0.99 \mathrm{Mg} / \mathrm{m}^{2} / \mathrm{m}$.y. in the late Miocene through 1.22 and $1.02 \mathrm{Mg} / \mathrm{m}^{2} / \mathrm{m}$.y. in the early and late Pliocene, respectively, to a high of $1.46 \mathrm{Mg} / \mathrm{m}^{2} / \mathrm{m} . \mathrm{y}$. in the Pleistocene. The highest rates are associated with the highest rates of accumulation of terrigenous detritus (clay, minerals, quartz, feldspar, and rock fragments). In fact, there is a direct relationship between terrigenous influx and organic carbon at all sites, whereas the rates of accumulation of biogenic silica (mostly diatoms) bear an inverse relationship to organic carbon. This suggests that the organic matter is primarily reworked terrigenous material associated with terrigenous clastic sediment transported to the sites. Therefore although the total organic carbon content is not diluted by high terrigenous input, the marine component resulting from surface water productivity (and diatom remains) may be swamped by the terrigenous component.

This conclusion is supported by various studies of the organic matter extracted from sediments recovered during Legs 56 and 57. On the basis of geochemical analysis, Gilbert et al. (this volume) state that at least 75 per cent of the insoluble organic matter in the samples they studied (mostly from shallow depths in the holes) was composed of terrestrial material (coaly, woody, and herbaceous matter). Less than 25 per cent was amorphous, possibly marine-derived. Rullkotter et al. (this volume) have come to the same conclusion, based on geochemical (gas chromatography) and optical studies of the kerogen concentrates. The reflectance study revealed a significant proportion of recycled vitrinite as well. The vitrinite-inertinite particles apparently became smaller and more rounded with distance from land, implying an effect of size sorting and abrasion during transport.

\section{Diagenesis of Organic Matter}

Very little thermal diagenesis of the organic matter has occurred. Most is classified as immature (Rullkotter 
TABLE 2

Data Used to Calculate Sediment Accumulation Rates

\begin{tabular}{|c|c|c|c|c|c|c|c|c|c|c|c|}
\hline Site & $\begin{array}{c}\text { Time } \\
\text { Interval } \\
\text { (m.y.B.P.) }\end{array}$ & $\begin{array}{l}\text { Average } \\
\text { Sedimen- } \\
\text { tation } \\
\text { Rate } \\
(\mathrm{m} / \mathrm{my})\end{array}$ & $\begin{array}{l}\text { Average } \\
\text { Bulk } \\
\text { Density } \\
\left(\mathrm{Mg} / \mathrm{m}^{2}\right)\end{array}$ & $\begin{array}{c}\text { Average } \\
\text { Water } \\
\text { Content } \\
(\%)\end{array}$ & $\begin{array}{c}\text { Total } \\
\text { Sediment } \\
\text { Accumulation } \\
\text { Rate } \\
\left(\mathrm{Mg} / \mathrm{m}^{2} / \mathrm{m} . \text { y. }\right)\end{array}$ & $\begin{array}{l}\text { Average } \\
\text { Per Cent }\end{array}$ & $\begin{array}{l}\text { us Component }{ }^{\mathrm{a}} \\
\text { Accumulation } \\
\text { Rate } \\
\left(\mathrm{Mg} / \mathrm{m}^{2} / \mathrm{m} . \mathrm{y} .\right)\end{array}$ & $\begin{array}{l}\text { Average } \\
\text { Per Cent }\end{array}$ & $\begin{array}{l}\text { ic Carbon } \\
\text { Accumulation } \\
\text { Rate } \\
\left(\mathrm{Mg} / \mathrm{m}^{2} / \mathrm{m} . \mathrm{y} .\right)\end{array}$ & $\begin{array}{l}\text { Average } \\
\text { Per Cent }\end{array}$ & $\begin{array}{l}\text { Ac Glass } \\
\text { Rate } \\
\text { Rate } \\
\left(\mathrm{Mg} / \mathrm{m}^{2} / \mathrm{m} . \mathrm{y} .\right)\end{array}$ \\
\hline \multirow{8}{*}{$\begin{array}{l}438 \\
\text { and } \\
439\end{array}$} & $0-2.0$ & 25 & 1.71 & 35 & 34 & 12 & 4.1 & 0.7 & 0.38 & $8.0-1.0$ & $2.7-0.3$ \\
\hline & $2.0-3.3$ & 110 & 1.45 & 47 & 108 & $30-38$ & $32.4-41.0$ & 0.75 & 0.87 & 3.0 & 3.2 \\
\hline & $3.3-5.2$ & 110 & 1.35 & 49 & 95 & $38-20-42$ & $36.1-17.0-39.9$ & 0.55 & 0.61 & $4.0-2.5$ & $3.8-2.4$ \\
\hline & $5.2-6.8$ & hiatus & - & - & - & - & - & - & - & - & - \\
\hline & $6.8-12.6$ & 37 & 1.53 & 39 & 42 & $32-15$ & $13.4-6.3$ & 0.55 & 0.25 & $5.0-1.5$ & $2.1-0.6$ \\
\hline & $12.6-13.8$ & hiatus & - & - & - & - & - & - & - & - & - \\
\hline & $13.8-16.0$ & 100 & 1.60 & 35 & 115 & $15-10-20-10$ & $18.8-12.5-25.0-12.5$ & 0.60 & 0.24 & $4.0-1.5$ & $5.0-1.9$ \\
\hline & $16.0-22.5$ & 30 & 1.68 & 30 & 41 & $10-<1$ & $4.1-<1$ & 0.50 & 0.15 & $6.0-6.0$ & $7.5-2.5$ \\
\hline \multirow[t]{3}{*}{435} & $0-1.8$ & 42 & 1.45 & 45 & 42 & $20-15$ & $8.4-6.3$ & - & - & $3.0-5.0$ & $1.3-2.1$ \\
\hline & $1.8-3.3$ & 37 & 1.38 & 55 & 30 & $15-20$ & $4.5-6.0$ & - & - & 5.0 & 1.5 \\
\hline & $3.3-5.2(?)$ & 58 & 1.46 & 52 & 55 & $15-40-20-35$ & $8.3-22-11-19$ & - & - & $1.0-5.0-0$ & $0.6-2.8-0$ \\
\hline \multirow[t]{4}{*}{440} & $0-0.9$ & 270 & 1.60 & 39 & 327 & $20-15-12-6$ & $65.4-49.1-39.2-19.6$ & 0.7 & 1.46 & $4.0-3.0$ & $13.1-9.8$ \\
\hline & $0.9-5.6$ & 105 & 1.62 & 35 & 133 & $4-13-10-6$ & $5.3-17.3-13.3-8$ & $0.8-0.9$ & $1.02-1.22$ & $5.0-4.0-3.0-4.0$ & $6.7-5.3-4.0-5.3$ \\
\hline & $5.6-6.4$ & hiatus & - & - & - & - & - & - & - & - & - \\
\hline & $6.4-7.8$ & 105 & 1.65 & 32 & 141 & $8.0-3.0$ & $11.3-4.2$ & 0.65 & 0.99 & 3.0 & 4.2 \\
\hline \multirow[t]{4}{*}{441} & $0-1.8$ & hiatus & - & - & - & - & - & - & - & - & - \\
\hline & $1.8-3.3$ & 175 & 1.60 & 40 & 214 & $25-16-16$ & $53.5-34.2-34.2$ & - & - & 2.5 & 5.4 \\
\hline & $3.3-5.2$ & 175 & 1.56 & 37 & 212 & $16-6$ & $33.9-12.7$ & - & - & 6.0 & 12.8 \\
\hline & $5.2-6.2$ & 175 & 1.95 & 20 & 228 & 3 & 8.9 & - & - & 7.0 & 20.9 \\
\hline \multirow[t]{5}{*}{434} & $0-0.1$ & 65 & 1.40 & 50 & $59^{\circ}$ & 30 & 17.7 & - & - & 20 & 11.8 \\
\hline & $0.1-1.8$ & hiatus & - & - & - & - & - & - & - & - & - \\
\hline & $1.8-3.3$ & 29 & 1.45 & 40 & 30 & 13-18 & $3.9-5.4$ & - & -3.0 & 0.9 & - \\
\hline & $3.3-5.2$ & 214 & 1.60 & 35 & 268 & $10-16-7-12$ & $26.8-42.9-18.8-32.2$ & - & - & 25 & 24.0 \\
\hline & $5.2-7.9$ & 64 & 1.80 & 30 & 96 & $5-11$ & $4.8-10.6$ & - & - & 25 & 24.0 \\
\hline \multirow[t]{4}{*}{436} & $0-1.8$ & 47 & 1.44 & 52 & 43 & $10-24-15-20$ & $4.3-10.3-6.5-8.6$ & 0.5 & 0.24 & $7.5-13$ & $3.2-5.6$ \\
\hline & $1.8-3.3$ & 37 & 1.43 & 56 & 32 & $15-25$ & $4.8-8.0$ & 0.35 & 0.15 & 15 & 4.8 \\
\hline & $3.3-5.2$ & 49 & 1.43 & 52 & 45 & $20-10-28$ & $9.0-4.5-12.6$ & 0.2 & 0.05 & $16-6$ & $7.2-2.7$ \\
\hline & $5.2-12.0$ & 14 & 1.48 & 48 & 14 & $15-10-15$ & $2.1-1.4-2.1$ & 0.1 & 0.04 & $9-16-2.5$ & $1.3-2.2-0.4$ \\
\hline
\end{tabular}

${ }^{\mathrm{a}}$ The average per cent and accumulation rate of the biosiliceous component varies greatly within certain of the time intervals. Thus several separate values were calculated for each of these parameters; they are shown by a series of numbers separated by hyphens.

et al., Gilbert et al., Sato, all this volume). This is not surprising because the present geothermal gradient is relatively low and varies from $3^{\circ} \mathrm{C} / 100 \mathrm{~m}$ (Site 438 site chapter) to $1^{\circ} \mathrm{C} / 100 \mathrm{~m}$ (Sites 440 and 441 site chapters). Rullkotter et al. (this volume) report relatively low mean vitrinite reflectance values $(0.30-0.45$ per cent $R)$. This suggests low maturity of the organic matter throughout the sequences studies. However, the Upper Cretaceous dark shales at the base of Hole 439 have a vitrinite reflectance value of 0.74 per cent $R$ (mean) and a mature $n$-alkane distribution. Rullkotter et al. suggest that this may be due to the effect of a local geothermal event which took place during the late Oligocene, since the lower Miocene sediments above were not affected. They call attention to the calc-alkaline igneous rocks of Oligocene age present as clasts in the Oligocene conglomerate at Site 439 as possible results of this event.

Sato (this volume) studied the humic acids spectroscopically and geochemically and also came to the conclusion that the organic matter in Legs 56 and 57 sediments if immature, with the exception of that in the Oligocene and Cretaceous sediments at Site 439.

Based on their gas chromatographic analysis of extractable saturated hydrocarbons, Gilbert et al. (this volume) contend that the sediment they analyzed have good potential as oil and gas source rocks (see Dow, 1977). Large amounts of methane are present in sediments (Whelan and Whelan and Sato, both this volume), but it is primarily of biogenic origin, generated under anaerobic conditions in the sediment after deposition (see Sato, this volume, for further evidence). The high rates of deposition and relatively high organic carbon content result in the rapid establishment of anoxic conditions, depletion of interstitial sulfate (Moore and Gieskes, this volume), formation of iron sulfide minerals, and bacterial fermentation reactions resulting in methane generation.

\section{Tectonic Deformation of Sediment}

Sediment at depth under the deep sea terrace and under the trench inner slope has been variable affected by tectonic stress. Figure 26 illustrtes the relationship between site location relative to the trench, depth of sediment lithification, and occurrence of structural deformation. Healed fractures, veins, and microfaults occur at all except Sites 435 and 436; these deformation features are described in detail by Arthur et al. and by Moore (both this volume). The depth to "lithified" or consolidated sediment (Arthur et al., this volume) at each site is progressively more shallow toward the trench, as is the general first occurrence of veins or healed fractures.

At Sites 438 and 439 faults and fractures (Figure 27) are confined mainly to the lower to middle Miocene interval. Major normal faults seen in JNOC Line 1 (Figure 2) appear to cut the sequence in this zone. The faults were active as late as the Pliocene and possibly in the Pleistocene (also see Nasu et al., this volume).

The first occurrences of healed fractures at Sites 440, 441 , and 434 is in upper Pliocene strata. Fracturing continues with variable intensity to the bottom of the holes. Open fractures may exist in situ in some of the sites at 


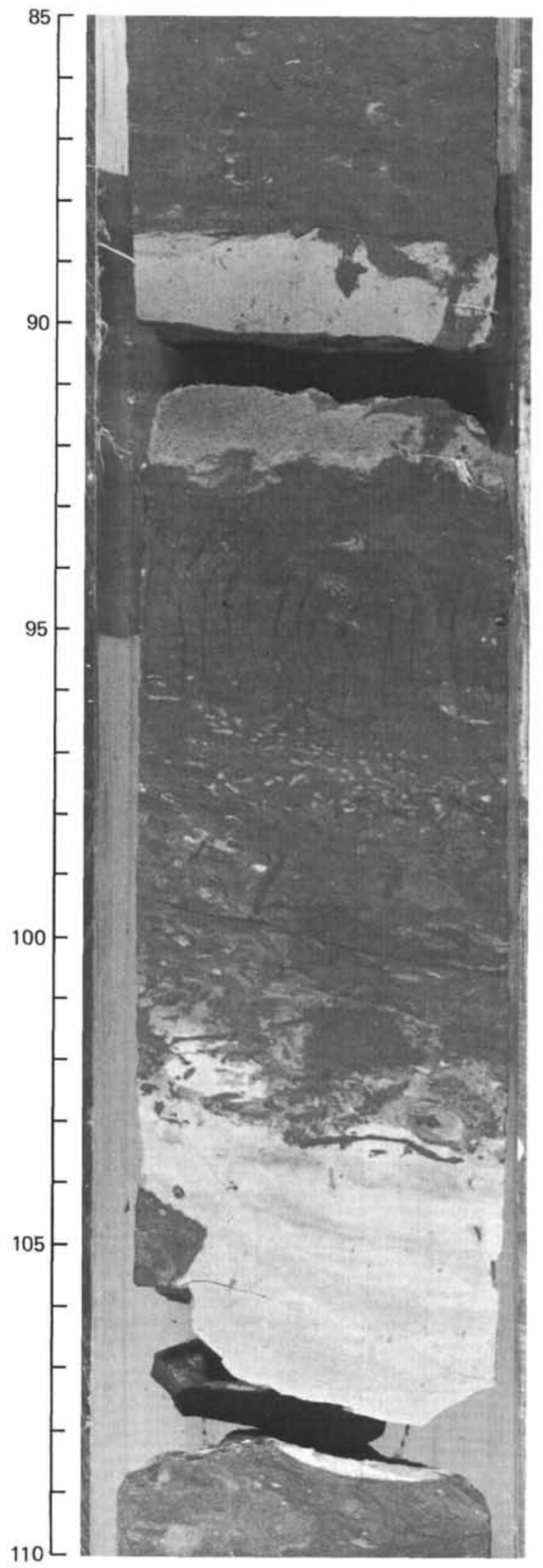

Figure 24. Leg 57, Sample 439-9-3, 85-110 cm: lower Miocene; several calcareous tuffs, partly replaced and cemented by low-magnesian calcite. Note intervening burrowed, dark olive gray claystone with sigmoidal veins. relatively shallow depths (See Arthur et al., this volume) (Figure 28). Recovery was poor in the fractured mudstones at Sites 441 and 434 , which are missing the Pleistocene overburden, whereas it was better at Site 440 , which retains a thick Pleistocene cap.

The intense fracturing at lower trench inner slope sites (Figure 28) may have been caused by a late Pliocene tectonic event, since sediment younger than that is not affected. However, continual tectonic stress imposed on the trench inner slope due to convergence as well as rapid rates of sedimentation of a relatively impermeable mud overburden may contribute to rapid consolidation, development of fractures, and excess fluid pressures in sediment more than a few hundred meters deep. The induced consolidation requires sediments to dewater through the fracture systems. At greater depth, after initial rapid dewatering, the fractures are rehealed by a combination of tectonic stress and overburden pressures (Figure 28). A similar process has been described by Carson et al. (1974) and Carson (1977) for sediments along the Oregon-Washington margin. This differs from the development of incipient cleavage described by J. Moore and Karig (1976) for deformed "accreted" sediments landward of the Nankai Trough (DSDP Site 298).

The development of fractures and fluid overpressuring in sediments on the slope may lead to downslope movement of the upper sediment sequence above the overpressured zone. This may have been the fate of the missing Pleistocene section at Sites 434 and 441 and may be a general process on many active margin slopes.

\section{SEDIMENT TRANSPORT AND DEPOSITIONAL FEATURES IN GEOPHYSICAL DATA}

The sediment sampled at Sites 438 and 439 on the deep sea terrace comes from the Neogene IshikariHidaka Basin, one of several large Neogene basins on the shelves around the Japanese Islands (Ishiwada and Ogawa, 1976). Sediment on the basin appears to have come from a source on Hokkaido and to a lesser extent from the northernmost part of Honshu. There may be local subbasins in the Ishikari-Hidaka Basin, as suggested by study of a grid of single-channel seismic records (Honza, this volume, and Figure 1; Honza et al., 1978). A series of folds strike parallel to the regional basin trend $(\mathrm{N}-\mathrm{S})$, and sediment is commonly ponded in broad synclines behind anticlinal ridges. Some of the apparent local basins are probably filled channels or troughs. JNOC multichannel Record 2 (Figure 2) allows identification of a filled trough that was cut into the underlying section (Figure 29). Beneath the trough the normal terrace section pinches out against the trough margin, indicating erosion or nondeposition. If the trough, ranging from 5 to $25 \mathrm{~km}$ wide, were interpreted as a simple depositional basin it would require that the upper Miocene sea floor beneath be bowed-up to prevent deposition through the early Miocene and then be depressed to become a local Pleistocene depocenter. We reject such an interpretation in favor of the channel hypothesis, because there is additional evidence of a filled channel in JNOC Record A (Figure 29). This line, which parallels regional structures, also parallels the 


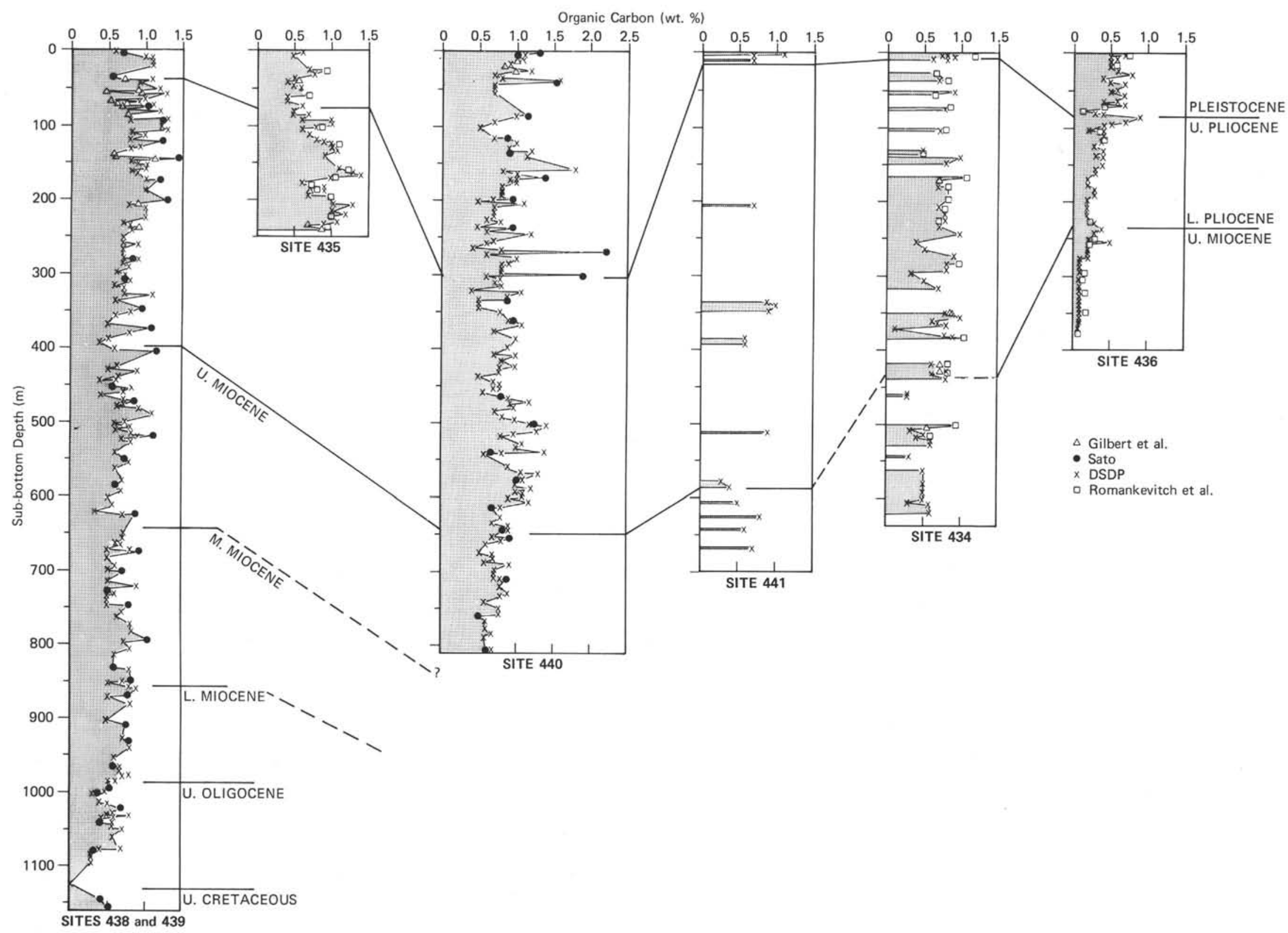

Figure 25. Organic carbon contents in sediment at all DSDP sites, Legs 56 and 57. See key for sources of data. 


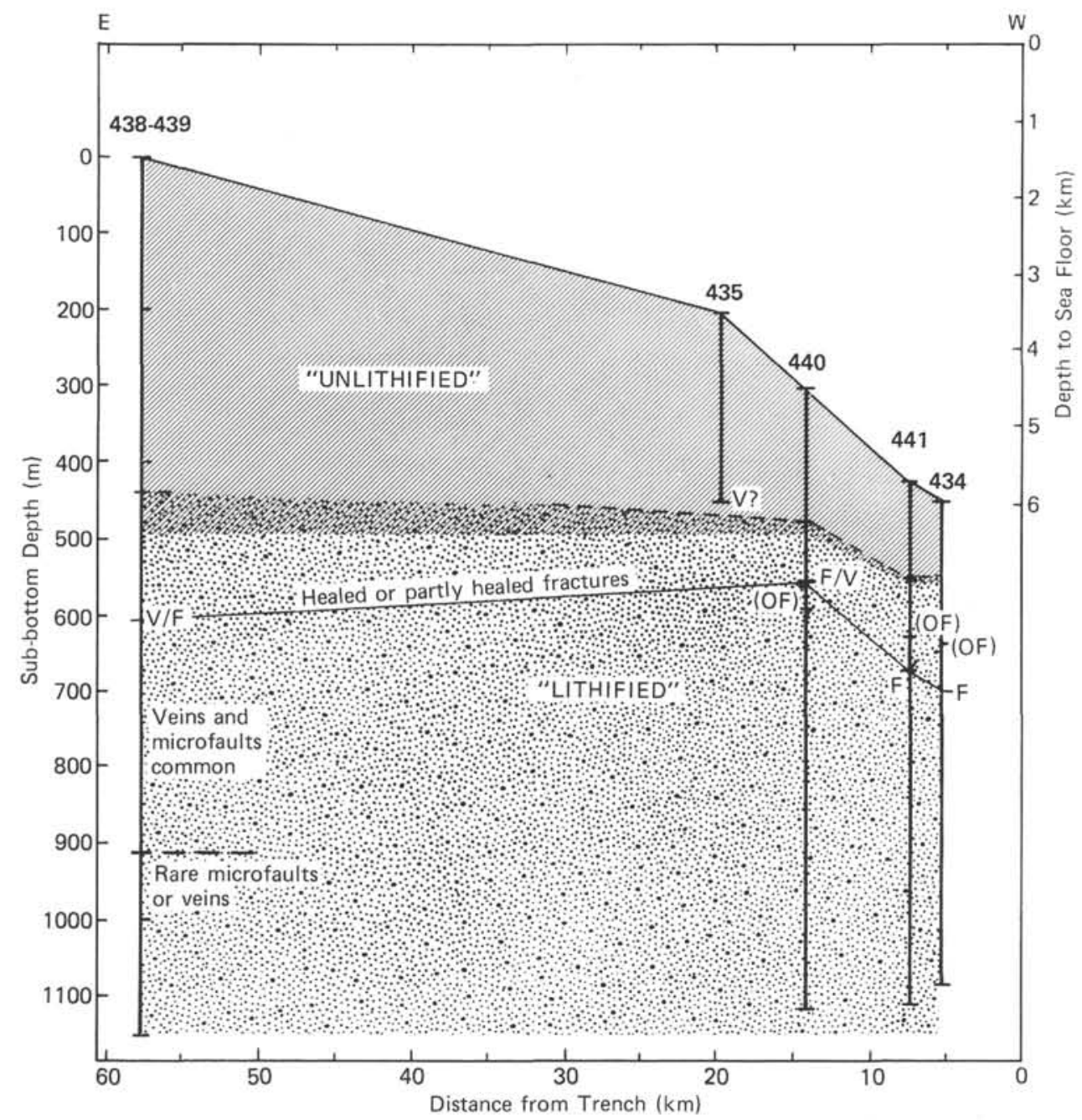

Figure 26. Depth of lithification or consolidation front and occurrence of healed fractures and veins at DSDP sites as a function of distance from trench (from Arthur et al., this volume). Healed fractures and veins occur predominantly in middle and upper Miocene sediment at Sites 438 and 439 and in upper Pliocene and older sediment at Sites 440, 441 and 434. No fractures occur at Sites 435 and 436 (on oceanic plate). (T.D. = total depth, $\mathrm{V}=$ veins, $\mathrm{F}=$ healed fractures, $\mathrm{OF}=$ open fractures.)

filled channel, or two separate filled channels can be seen; the channel, affording an axial section through this feature. Thus two sections of a filled channel in single-channel seismic Records 19 and 19-1 are the same channel detailed in JNOC Record A (Figure 29). Between these two sets of records there is only one singlechannel record, and so although the existence of a single filled channel is not proven, it is likely. If the filled channel is continuous, as suggested in Figure 29, it extends about $200 \mathrm{~km}$ toward Hokkaido, where it cannot be followed north of the south bank of a large active channel system running west to east at the juncture of the Japan and Kuril trenches (Figure 1).

The terminus of the now-filled channel was on the lower trench inner slope or was the trench itself. The channel is absent in a Shell Oil Company multichannel seismic line (Beck et al., 1976), and a large re-entrant to the trench inner slope is present between the two lines
(Figure 1 and Site Summary Chart, Sites 438-439, back pocket, Pt. 1). Channels are also present on the trench; for example, JNOC multichannel seismic Record C (Figure 30, a crossline to JNOC Record 2 in about 5500 meters water depth) shows such a channel. This channel system appears to be relict. It is partially filled with sediment, and the present trench downslope from it appears to have little sediment fill.

Filling of the channel on the deep sea terrace appears to have been in response to tectonic uplift as indicated along JNOC Record 2, because the channel fill depocenter has migrated landward as the anticline forming its seaward bank was uplifted. Perhaps the channel was also disrupted by the local uplift transverse to the margin that occurs between Records 20 and 21 (Figures 1 and 29). Note that the channel is shallower at the position of Record 21 than elsewhere, and erosion may not have been able to keep pace with the uplift. Because 

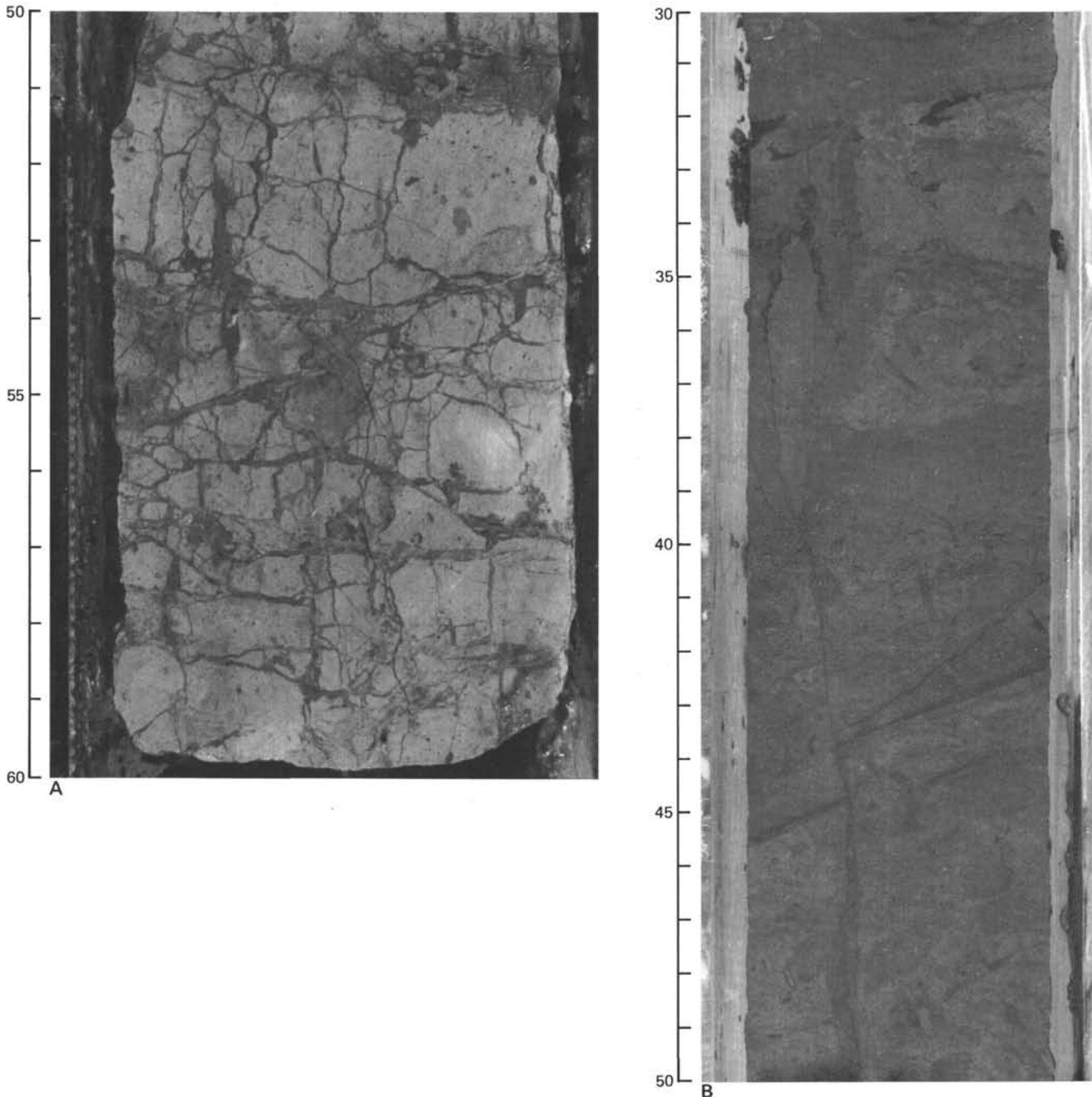

Figure 27. A. Leg 57, Sample 438A-66-2, 50-60 cm: middle Miocene brecciated greenish gray limestone. Note no relative displacement of breccia fragments. B. Leg 57, Sample 438B-4-1, 30-50 cm: middle Miocene grayish olive green mottled diatomaceous claystone, showing high-angle reverse fault with about $1 \mathrm{~cm}$ displacement and veins at about $34 \mathrm{~cm}$.

tectonic features form its banks, the initiation of the channel and the cause of its filling appear related to local tectonism. Filling of the channel cannot be dated precisely, because the seismic stratigraphy cannot be directly correlated between the channel and Sites 438 and 439. The fill appears to be late Pliocene or younger.

The large modern channel system at the juncture of the Japan and Kuril trenches begins in Ishikari Bay and empties at the juncture with the trench. Therefore it forms a relatively direct transport path from a large terrigenous source area to the trench.

In the Japan Trench, immediately south of the channel system terminus, there is a peculiar feature that appears linked with the channel. In multichannel seismic records the feature is a low extension or toe in front of the lower trench inner slope which fills and displaces the trench axis seaward (Figure 31 ). The toe has a nearly level but highly diffractive upper surface, indicating a 


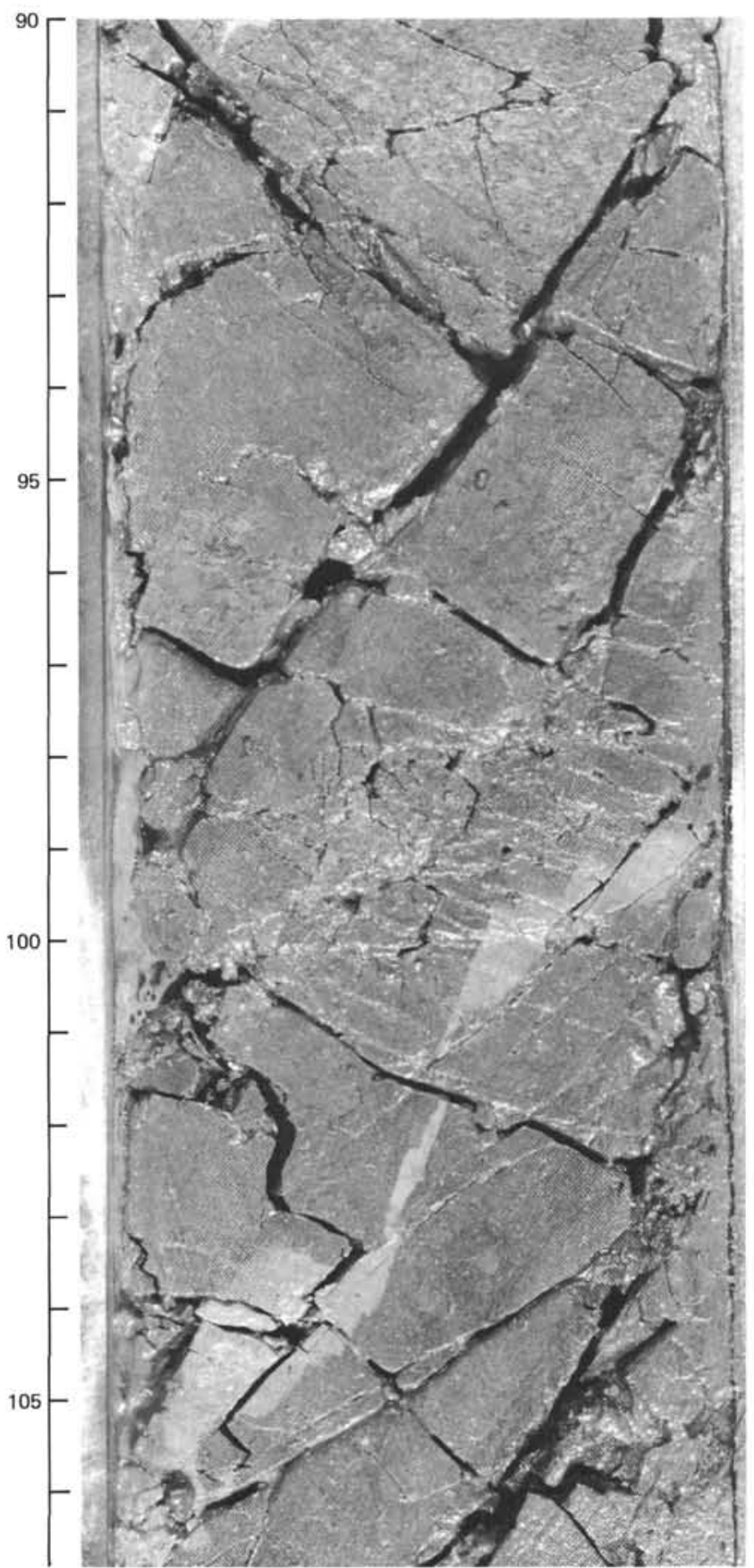

Figure 28. Leg 56, Sample 434B-9-2, 90-117 cm: lower Pliocene vitric diatomaceous silty clay with layer of yellowish gray marlstone, exhibiting progressive offset along a series of healed microfaults.

hummocky sea floor (Figure 31). It is underlain by ocean crust, and in JNOC Record 1 (Figure 31A) the ocean sediment section can be followed uninterrupted $10 \mathrm{~km}$ or more beneath the toe. Rare, short, faint reflections at a near-horizontal attitude are the only indication of internal structure of the toe not obscured by the surface diffractions. The size of the toe is greatest at the channel terminus and becomes systematically smaller away from the channel. Thus the data indicate that the toe is an irregularly stratified sediment body filling the trench and that it consists of blocks or masses large enough to form a rough, hummocky surface. It appears to be deposited upon, rather than scraped off, the ocean crust. Such features indicate that the toe may be the product of mass movement of sediment down the canyon system (Hidaka Trough).

The trench midslope terrace is a long, narrow topographic break about $4 \mathrm{~km}$ below sea level that corresponds to a major juncture between continental and intermediate crust (see Nasu et al., this volume). The terrace appears to be semicontinuous for at least $175 \mathrm{~km}$ along strike and must be a trap for sediment transported in transverse channels across the trench inner slope. Its importance as a sediment trap is indicated by the ponded upper Pleistocene sediment recovered at Site 440 and by the local sediment ponds resolved in seismic records (Figure 31C). The topographic terrace is formed by ponding or trapping of sediment behind an outer ridge which is commonly overwhelmed by the volume of sediment moving down the trench slope (Figure $31 \mathrm{~A}$ and B). Perhaps it is significant to note that the trench midslope terrace has a pond of sediment as wide as or wider than that found in the trench (Figure $31 \mathrm{C}$ ). At Site 440 ponding began in the earlist Pleistocene.

The axis of the Japan Trench at depths greater than 7000 meters is beyond the sampling capabilities of Glomar Challenger; however, three piston cores from the northern Japan Trench were recovered during Cruise GH 76-2 by the Geological Survey of Japan (Honza, 1977). The cores contain mainly clay and mud turbidites, ash, and minor fine sand (Hesse, 1977). Seismic records indicate very little ponded trench fill, although the resolution of the seismic technique at these water depths may be from 50 to 100 meters. The materials recovered from the trench by piston coring are not unique and would be difficult to distinguish from trench inner slope sediment.

Deposition mechanisms in the deep ocean basin are mainly pelagic, as indicated by the thick sedimentary layer which conforms uniformly to the topography. This is seen particularly well in single-channel seismic records (Figure 32; Ludwig et al., 1966; Tamaki et al.'s [1977] fig. 10). Bottom currents in the deep Pacific Basin off Japan are strong enough to produce the moats around Takuyo-Daiichi and Erimo seamounts off Hokkaido and around an unnamed seamount off Honshu (Tamaki et al., 1977; Nasu et al., this volume; Site 436 Site chapter). There is a possibility that fine-grained clastic material could be transported across the trench by each strong currents. Some coarser-grained material deposited from turbidity currents could reach the trench outer slope in the vicinity of the large toe, where the trench axis is filled. The recovery of turbidites in piston cores from areas seaward of Mid-America Trench off Guatemala (Ladd et al., 1978), the Peru-Chile Trench (Prince et al., 1974) and in the south China Sea (Damuth, 1979) may have originated in a similar manner. However, no significant coarse-grained clastic sediment was found at Site 436 . 


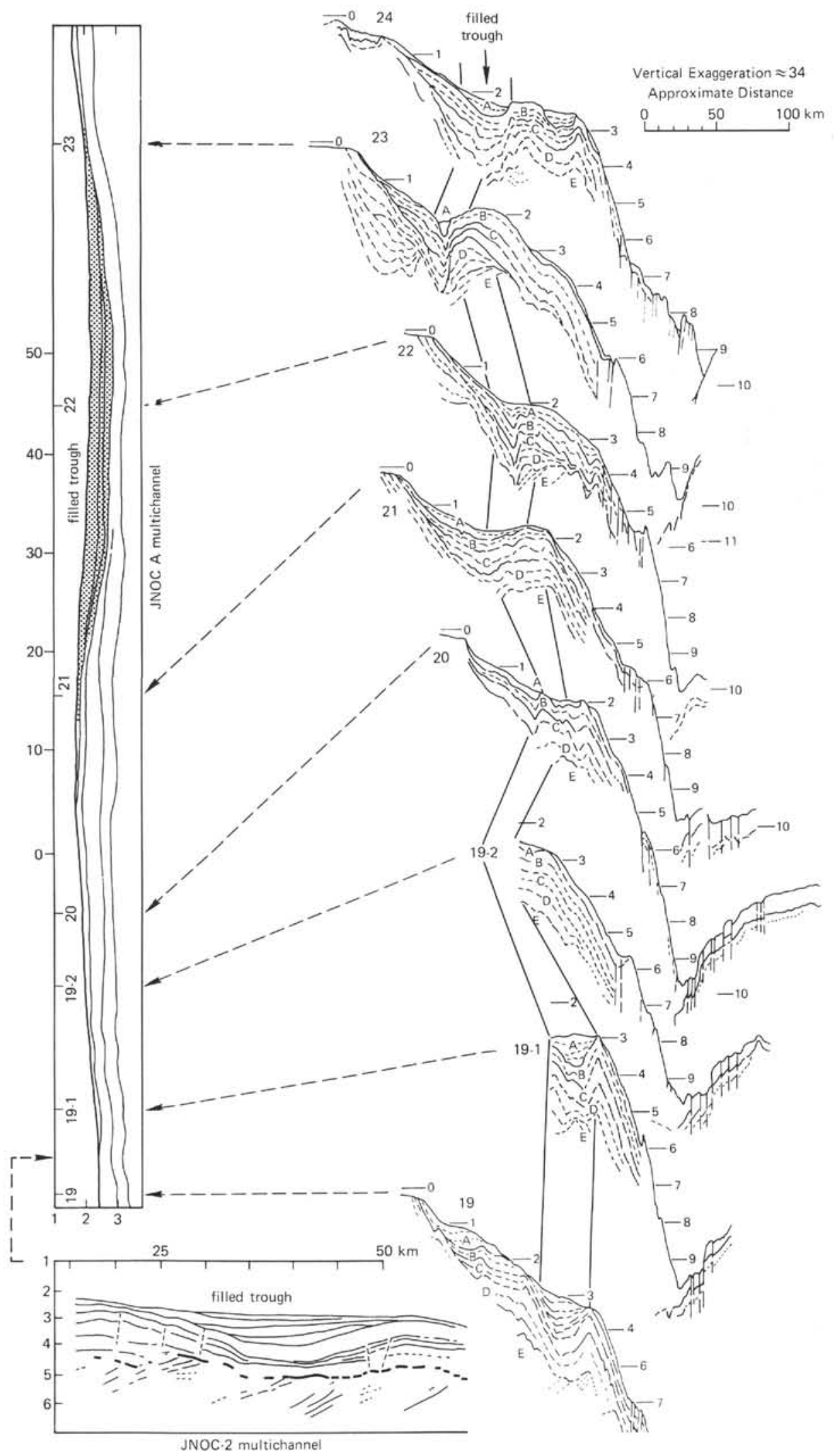

Figure 29. Single-channel records (Honza, 1977) and portion of JNOC multichannel Records $A$ and 2 across the deep sea terrace and trench inner slope, showing location of filled channel. Channel was active in the pre-Pleistocene and extended across fore-arc region from near Hokkaido to trench inner slope near Record 20 (see Figure 1). Channel was probably filled in the Pleistocene. 


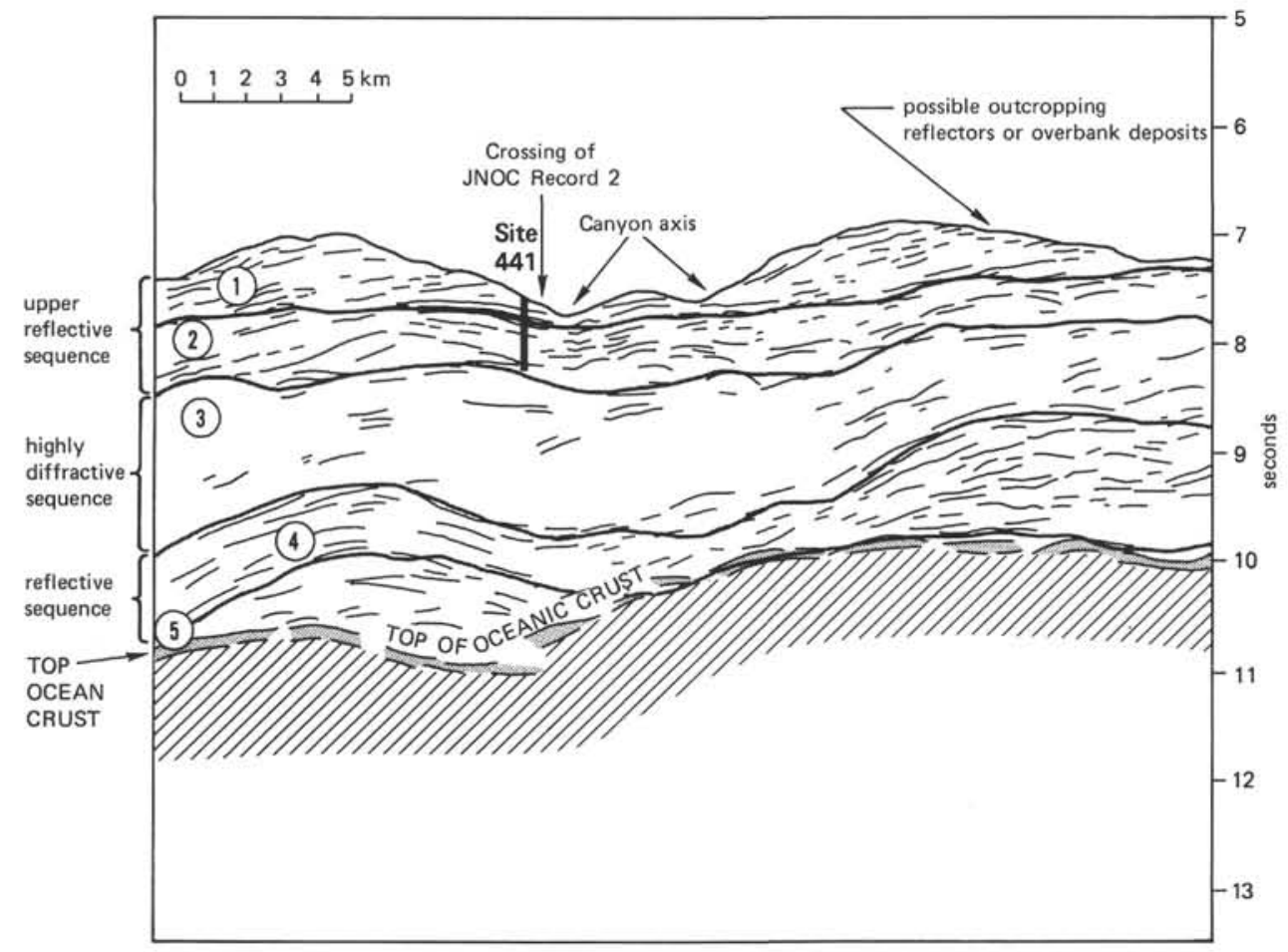

Figure 30. Interpretive sketch of JNOC Record C, showing inferred channels or slump scars and possible overbank deposits.

\section{EVOLUTION OF SEDIMENTATION IN THE FORE-ARC REGION}

The record of sedimentation prior to the late Miocene is known only from seismic records and from the sequence cored at Sites 438 and 439 on the deep sea terrace. The highly diffractive reflector in multichannel seismic records that extends throughout the region under the deep sea terrace and out to the midslope terrace is an angular unconformity. The unconformity represents a subaerial erosion surface on the Oyashio paleolandmass, and at Sites 438 and 439 it is overlain by nonmarine conglomerate, above which are sandstones deposited in shallow water up to 500 meters deep (Keller, this volume). Thus the area of Sites 438 and 439 was above sea level during the Paleogene and subsided below sea level during the latest Oligocene. The diffractive horizon at the angular unconformity is inferred to be a subaerial erosion surface across the outer part of the margin (Nasu et al., von Huene et al., both this volume). The Neogene is a transgressive (onlapping) sequence on the erosion surface, and in seismic records the transgression continues seaward of Sites 438 and 439 at least to the top of the trench inner slope. This indicates that the surface is younger to the east. The strata beneath the unconformity are Early Cretaceous at Site 439 an also may be younger seaward. The sequence at Sites 438 and 439 in combination with the multichannel seismic records enables us to infer a history of subsidence and sedimentation during the Neogene for the fore-arc region off northern Honshu. We will first discuss the record at these sites.

\section{Sedimentary and Subsidence History on the Outer Part of the Margin}

Figure 33 is a "van Hinte" diagram showing the history of subsidence and sediment accumulation at Sites 438 and 439 . The subaerial erosion surface subsided below sea level during the late Oligocene (ca. 22-24 m.y.B.P.). The rate of subsidence was in excess of 250 $\mathrm{m} / \mathrm{m} . \mathrm{y}$. through the early Miocene, and sedimentation rates were relatively low $(30 \mathrm{~m} / \mathrm{m} . \mathrm{y}$. $)$, so that the sea floor had subsided to at least $1.5 \mathrm{~km}$ below sea level by the end of the early Miocene. Because sediment loading was negligible and the relative sea level rise during the late Oligocene-early Miocene postulated by Vail et al. (1977) is not of this magnitude, we infer that the subsidence was probably caused by tectonism. We do not know precisely when subsidence was initiated at Site 439 , since the Oyashio landmass could have had significant relief above sea level. However, subsidence probably began sometime during the late Paleogene, because landward the unconformity surface is progressively onlapped by older strata, perhaps of Paleogene age (see Nasu et al., this volume). It appears that subsidence below sea level first occurred landward and progressed seaward (to the east) through time.

In all multichannel seismic lines, successively younger strata downlap seaward against the diffractive unconformity surface from the west end of the records to about the upper trench inner slope (Nasu et al., this volume). If downlap represents the first sedimentation as the sea transgressed over the subsiding Oyashio landmass, as it does near Sites 438 and 439 , then Oyashio 

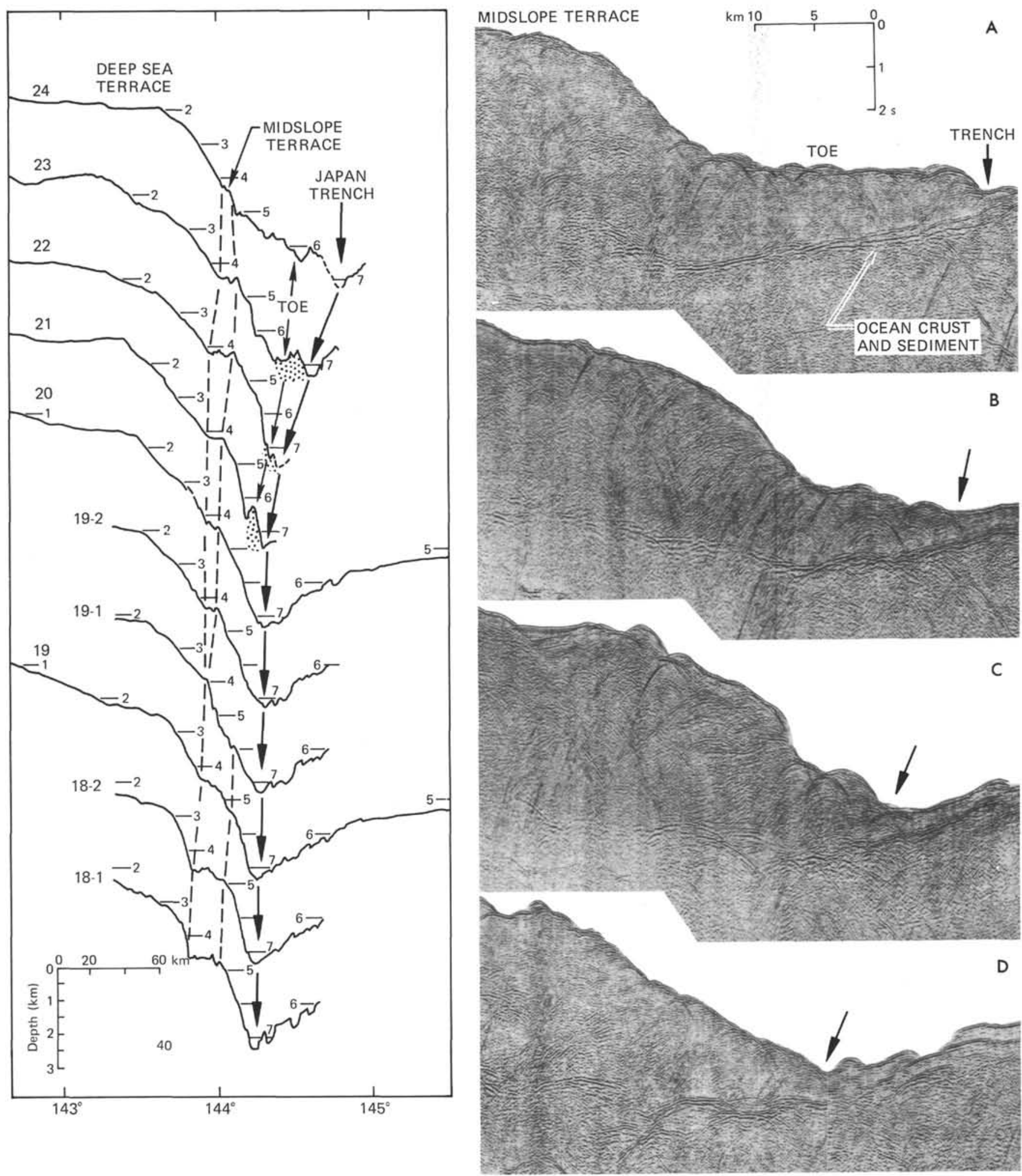

Figure 31. Multichannel seismic records A - JNOC Record 1; B - Record 78-3; C - Record 78-4; D - JNOC Record 2) and bathymetric profiles (from Honza, 1977) across the trench inner slope. Note the pronounced toe in (A) which diminishes in size southward. (For location of seismic records, see Figure 1.) 


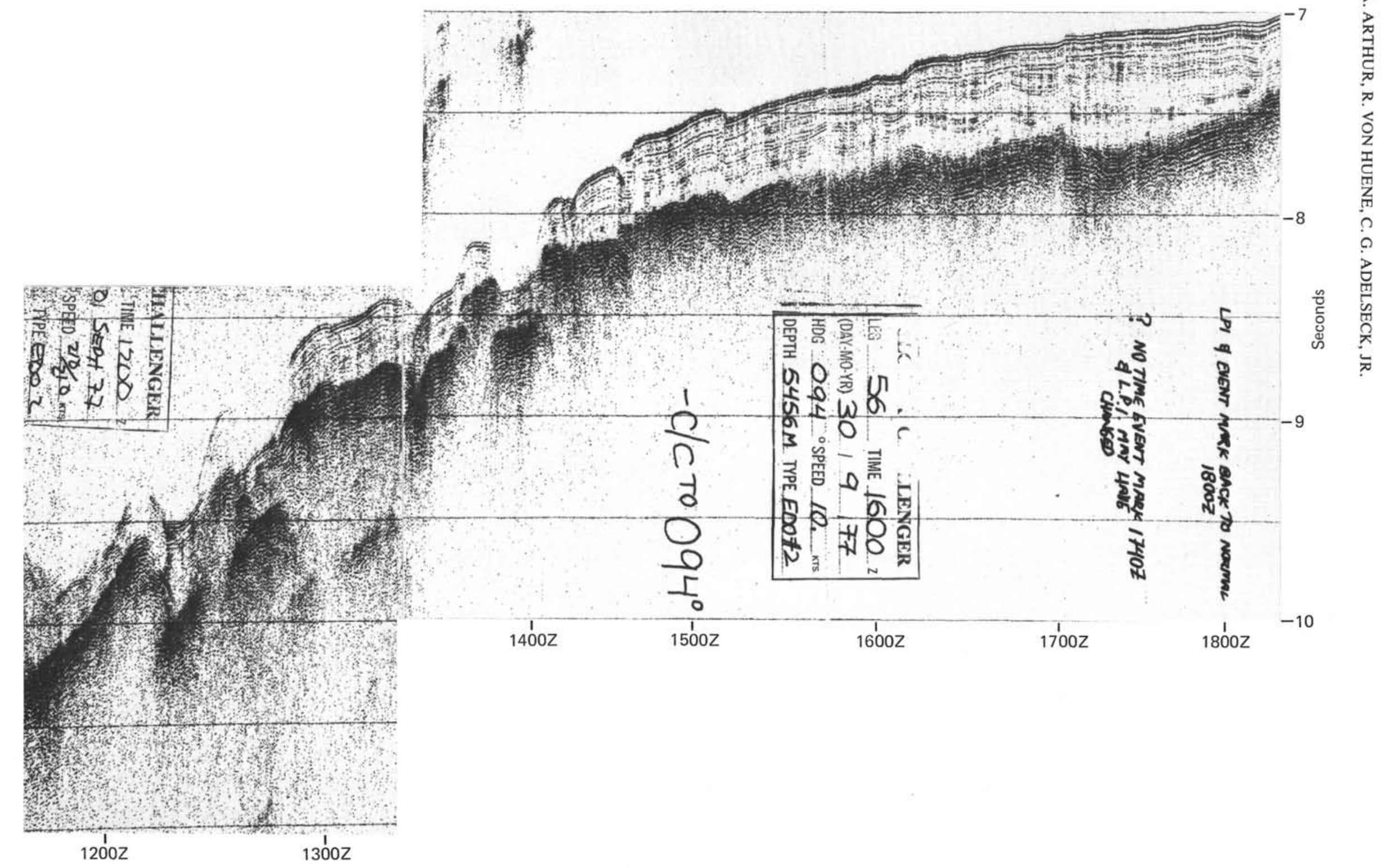

Figure 32. Single-channel (Glomar Challenger) seismic record on trench outer slope. Note reflector sequence, which conforms to topography, and normal faulting of sediment section and crust along the line. 


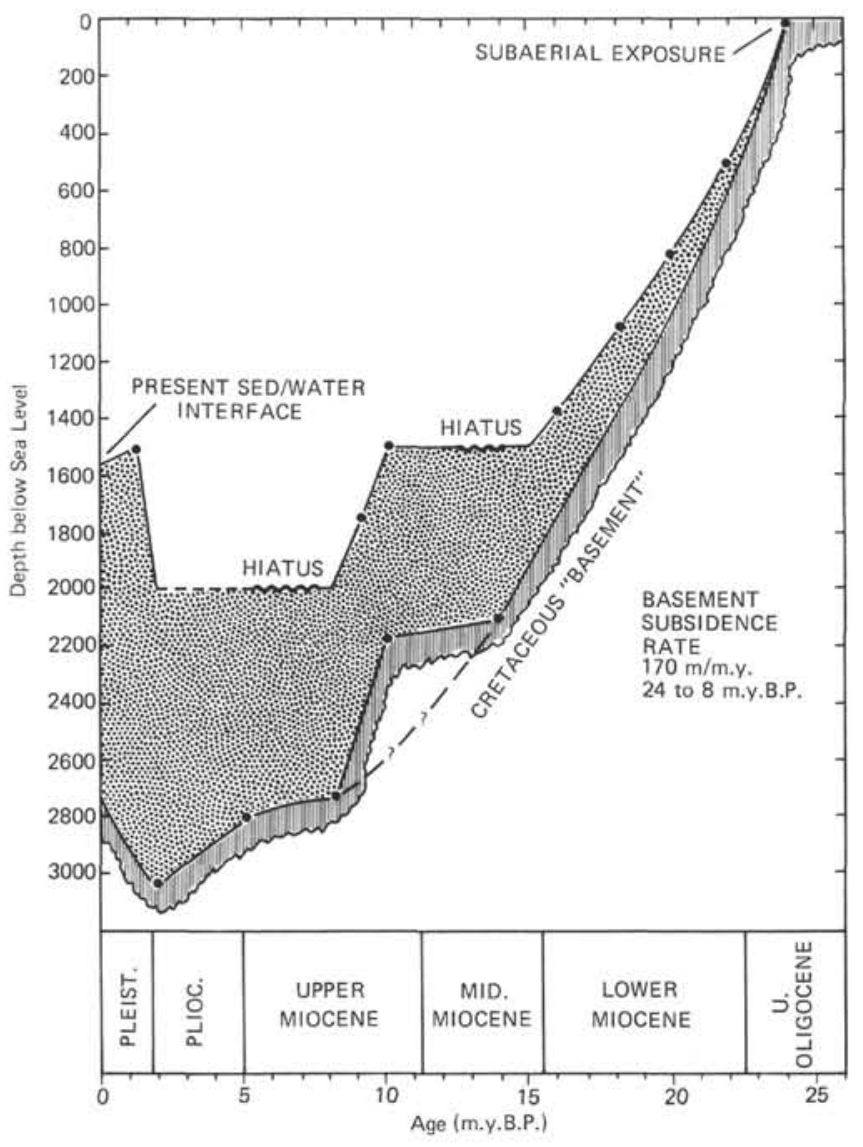

Figure 33. "Van Hinte" diagram depicting the relationship between basement subsidence and sedimentation through time at Sites 438 and 439, on the deep sea terrace. Corrections for sediment compaction have been applied as per van Hinte (1978). Depth to the sea floor is known for two points: (1) the time (ca. 24 m.y.B.P.) at which the "basement" surface subsided below sea level and (2) the present depth. The remaining history of sea floor depth is inferred from benthic foraminiferal evidence supplied by Keller (this volume). Note that there is no control on depth between 2000 and 4000 meters; therefore, during the interval between 8 and 2 m.y.B.P. the sea floor may have actually subsided below 2000 meters.

steadily subsided through the early Neogene. By the late Miocene most of the landmass had subsided below sea level. Therefore most of the sedimentary record sampled at Sites 435, 440, 441, and 434 (upper Miocene and younger) probably represent sedimentation after the landmass ceased to be a source terrain. The deepest sedimentary rocks sampled on the trench inner slope contain no major evidence of nearby sources of coarse clastic detritus or of shallow water faunal material.

Interpretation of multichannel seismic records suggests a seaward shift of sediment depocenters in response to progressive subsidence of the outer part of the margin (Figures 2 and 34). In two dimensions the seaward shift is shown well in JNOC Records 1 and 2. Each successive depocenter illustrated in Figure 34 is about 0.5 to $1.0 \mathrm{~km}$ thick, compared to a maximum $2.8-\mathrm{km}$ thickness in Neogene deposits. The pre-middle Miocene depocenter seen in Record 2 is landward of Sites 438 and 439 on the deep sea terrace. The late Miocene depocenter was located somewhat seaward of the sites but still on the deep sea terrace. The most rapid seaward shift, however, occurred between the late Miocene and early Pliocene, coincident with the final subsidence of Oyashio below sea level. It appears that major and rapid subsidence occurred at the seaward edge of the margin, now the terrace edge or trench upper slope, whereas subsidence had diminished on the inner portion of the deep sea terrace. This suggests that subsidence progressed seaward in the form of a wave. The axis of the Pliocene depocenter now occurs well down the trench inner slope (approx. $3500 \mathrm{~m}$ water depth) in JNOC Record 1 and at the top of the slope (approx. $2500 \mathrm{~m}$ ) in Record 2 (Figure 2). In JNOC seismic records the seaward side of Oyashio is obscured or missing, but the Shell Oil Company record, which was shot across the margin just south of JNOC Line 2 (see Beck et al., 1976), shows an apparent landward onlapping sequence of younger strata over the unconformity surface.

Upper Miocene-Pliocene sedimentation at Sites 435, 440,441 , and 434 reflects the evolution just described. At Site 435 the drill penetrated only the Pliocene and Pleistocene on the upper trench inner slope. The site was positioned where older reflectors appear to crop out on the slope, but perhaps its location slightly off the multichannel Record 2 may have resulted in drilling where the older strata are still covered by Pleistocene beds. At any rate, the Pliocene accumulation rates for total sediment and those for the diatom and volcanic glass fractions are less than half those at Site 436 , in the ocean basin. The accumulation rates for the upper Miocene and Pliocene of Sites 440 on the midslope terrace and for 441 and 434 farther down the trench inner slope are high for total sediment, with the highest upper Miocene rate at Site 441 and Pliocene rate at Site 434. These rates are similar to those of the ponded Pleistocene at Site 440 , on the midslope terrace. Accumulation rates of biogenic silica (diatoms) at these sites differ little from those on the deep sea terrace (Site 438) but are greater than those on the ocean plate (Site 436). The accumulation rate of volcanic glass disseminated in sediment at Site 436, however, is about three to five times that in the upper Miocene at Sites 438 and 439 and during the late Miocene and early Pliocene at Sites 441 and 434 . The values at Site $\mathbf{4 3 6}$ are similar to those in the Pleistocene at Site 440. Much of this volcanic material on the trench inner slope probably represents clastic influx to the sites. The relatively high accumulation rates and sediments of the upper Miocene-Pliocene section at Sites 434 and 441 suggest that the lower trench inner slope had a more shallow inclination and/or had a slope basin similar to the present midslope terrace basin. Sand layers, redeposited mudstone, breccias, and slumped beds were observed in some cores at Site 441. However, there is now little or no sedimentary record of the Pleistocene at Sites 441 and 434 , indicating a major morphotectonic change during the late Pliocene-Pleistocene. The upper Miocene and Pliocene sequence at Site 440 was deposited at 
M. A. ARTHUR, R. VON HUENE, C. G. ADELSECK, JR.
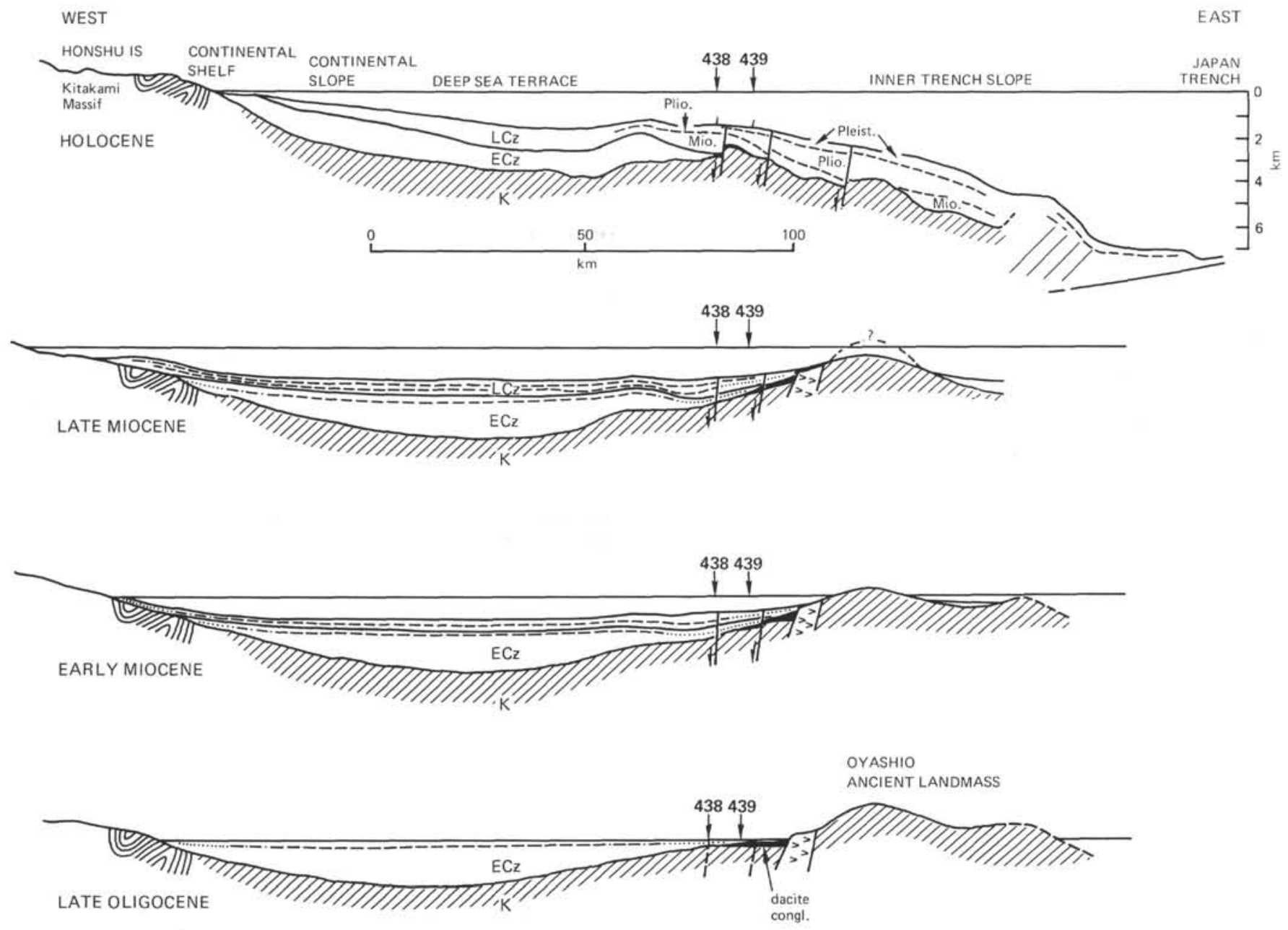

Figure 34. Schematic tectonic and sedimentary evolution of the fore-arc region off northern Honshu from the late Oligocene through the Holocene. Note the uplifted "outer arc high"'(Oyashio landmass), which subsided rapidly during the Miocene; note also the progressive seaward migration of sediment depocenters through time. Events on the seaward portion of the "accretionary prism" or lower trench inner slope are not shown. Several periods of accretion and tectonic erosion may have occurred during the Neogene (see von Huene et al., this volume).

rates significantly lower than at Sites 434 and 441 . The rates of sedimentation increased abruptly at Site 440 during the latest Pliocene (Figure 13), to which we assign the formation of the present midslope terrace basin. This may have been coincident with the event leading to the missing Pleistocene at Sites 434 and 441 .

At Site 441 only the subhorizontal slope sediment above dipping layers under the lower part of the trench inner slope was penetrated. However, at Site 434 the tilted horizons below the slope sequence may have been penetrated. Poor recovery was characteristic of both sites, but the tilted layers are upper Miocene and consist of vitric mudstone and muddy tuffs. The tilted layers may represent part of the accreted stack, but the sediment differs from sediments deposited above oceanic crust in the ocean basin by its high ash content and accumulation rate (Figure 13). Therefore it is difficult to say whether or not it was accreted from the ocean plate or represents uplifted and tilted trench sediment upon which the subhorizontal slope sequence was deposited.

\section{PLIO-PLEISTOCENE SEDIMENTATION AND TECTONICS}

Subsidence at Sites 438 and 439, seaward migration of depocenters on the deep sea terrace, and sedimentation in the lower trench inner slope were changed significantly during a tectonic event in the latest Pliocene or perhaps extending into the early Pleistocene. These simultaneous events may have been the result of yet another event that changed the morphology of the deep sea terrace and trench inner slope and altered patterns of sediment dispersal.

Subsidence of the deep sea terrace in the vicinity of Sites 438 and 439 decreased in the late Miocene, and, beginning in the late Pliocene, uplift of several hundred meters occurred based on benthic foraminiferal assemblages (Figure 33). Sedimentation rates dropped significantly from the late Pliocene to the Pleistocene.

Evidence from benthic foraminiferal assemblages at Site 435 (Thompson, this volume) suggests that the sea 
floor in the vicinity of this site, now at about 3400 meters, was uplifted from below the CCD (lower than 4000 meters) during the late Pliocene-Pleistocene.

At Site 440 , on the midslope terrace, accumulation rates were more than twice as high in the early to late Pleistocene than in the late Miocene through Pliocene. Graded volcaniclastic sand and silt beds occur in the upper Pleistocene sequence. This suggests that the midslope terrace basin formed during the late Pliocene to early Pleistocene. If the pervasive fracturing, now healed, is used as evidence of a phase of tectonic deformation or a period of accelerated deformation, it must have ended by the late Pliocene, since lower Pleistocene sediments at Site 440 , although partly lithified, are not faulted or fractured and the entire sequence from the upper Pliocene to the bottom of the hole is (Figure 26; see Arthur et al., this volume).

The lower Pleistocene and perhaps some upper Pleistocene sediment are missing at Sites 434 and 441 on the lower part of the trench inner slope. The upper Pliocene at Site 434 is anomalously thin and the lower Pliocene exceptionally thick. Healed fractures and faults occur in the upper Pliocene and in older sediments at both sites. There is evidence also for repetition of some upper and lower Pliocene diatom zones at Site 434 which may contribute to a thick lower Pliocene section. The repetition may be due to repeated imbricate thrust faults (see site chapter for Site 434) or to the emplacement of several large but coherent slump masses. These thrust faults or slumps apparently did not occur at Site 441 about $5 \mathrm{~km}$ up the slope, but they again point to a late Pliocene tectonic event. The slope in the vicinity of Sites 441 and 434 must subsequently have been oversteepened, because during most of the Pleistocene sediment apparently did not accumulate there or, if deposited, it was not stable and later slumped. Subhorizontal strata now crop out on the slope, as seen in the seismic records (Figure 31).

A major north-south channel on the upper part of the trench inner slope and the deep sea terrace traced from single-channel Record 19 north to the Hidaka Trough off Hokkaido (Figure 29) was suddenly filled and became inactive during the late Pliocene to Pleistocene. The depocenter of this broad channel underwent a progressive landward shift during the Pleistocene, while strata deeper in the channel were tilted slightly landward. The sudden filling and landward shift of the channel axis implies an uplift of the outer edge of the deep sea terrace and upper trench inner slope during the late Pliocene or early Pleistocene. This channel was probably an important conduit for sediment with Hokkaido-Honshu provenance to travel perhaps $200 \mathrm{~km}$ or more from the northern inner part of the fore-arc basin to the outer edge, where it spilled over the slope. The trench is now nearly empty of sediment south of JNOC Record 2, and little sediment has accumulated over much of the trench inner slope, except perhaps in the midslope terrace basin. This is at least in part a function of the cutting off of the main sediment supply because of a decrease in gradient across the fore-arc basin and filling of the channel and because of the increase in gradient in the trench inner slope.
One consequence of the filling and cutting off of the channel is that much of the sediment originating in northern Honshu and southern Hokkaido is now captured by the Hidaka Trough (Sato, 1973) and is funnelled directly east across the fore-arc region to the trench inner slope. A peculiar feature in this region (see Figure 1 and Honza, 1977) is the dissected topography of the trench inner slope and the presence of a large toe (Figure 31) at its base. The toe is anomalous as it occurs only offshore of the region fed by the Hidaka Trough and diminishes in width and thickness southward. On the basis of its rough surface topography and general lack of coherent internal reflections, we interpret the toe as an accumulation of one or more large slump masses. These have apparently slid off the trench inner slope, accumulated in the trench, and have actually pushed the trench axis seaward more than $15 \mathrm{~km}$. The slump masses are probably the result of high rates of sedimentation on an oversteepened slope which created overpressured zones at depth, as in the Gulf Coast, U.S. region (e.g. Booth, 1979), and are probably Pleistocene and younger. Nowhere else along the Japan Trench axis is there such fill (e.g., Inouchi et al. 1977) except off the mouth of Tokyo Bay, where the submarine fore-arc region narrows and slope canyons connecting the bay with the trench feed large volumes of sediment to the trench.

Based on the aforementioned evidence, we suggest that a major change in the structure and topography of the fore-arc region off northern Honshu occurred during the latest Pliocene-early Pleistocene. This tectonic disturbance caused a reorganization of pre-existing sedimentation patterns and shifted the locus of sedimentation from the trench inner slope and possibly the trench off Honshu north to the lower trench inner slope seaward of Hidaka Channel. Major normal faults seen in the multichannel seismic records across the margin appear to be late Pliocene or older. A crossing of the midslope terrace basin in multichannel Record 78-4 (Figure 31C) shows an episode of tilting of deeper reflectors which, though undated, may also have occurred in the latest Pliocene-early Pleistocene. Shallower reflectors in that basin are horizontal. It is interesting to note that a peak in explosive volcanism also occurs in the mid-Pliocene in the Tohoku arc on Honshu, as evidenced by an increase in ash layer frequency and in accumulation rates of volcanic ash at some of the DSDP sites (Figures 22, 23). We do not know the ultimate cause of the event which produced all of these features. Presumably there was some sudden change in the style of subduction or amount of material subducted. A large amount of sedimentary material probably reached the trench during the Miocene-Pliocene off northern Honshu; however, now the trench is empty and a large volume of material has apparently been slumped from the trench inner slope. Sediment accretion to the base of the slope appears to have been very minor in this area (see von Huene et al., this volume). We speculate that during the Pliocene the overfilling of the trench caused the sudden subduction of a large volume of sediment - a bite off the base of the inner slope - and its volume and high water content caused a pronounced uplift and tectonic 
jostling of the outer edge of the margin, from the midslope terrace seaward. Part or all of this mass may be under the edge of the deep sea terrace. Perhaps some of the sediment was carried down the subduction zone to below the arc, rather than being accreted or underplated in the fore-arc region, which would have increased explosive volcanism about $2 \mathrm{~m}$.y. following the initial subduction. This is of course highly speculative, but at present we are not aware of any other major change in rates or directions of subduction in this region during the Pliocene that could have caused such an event.

\section{RECOGNIZING SEDIMENTARY ENVIRONMENTS IN FORE-ARC REGIONS}

Recognition of sedimentary and morphotectonic environments in ancient fore-arc settings is of major concern because of its importance to the reconstruction of the sedimentary-tectonic evolution of continental margins. Recognition remains problematic, however. An essential aspect of the problem is the recognition of "accreted" material-that is, sediment scraped off the lower or oceanic plate and added to the wedge at the leading edge of the upper plate during subduction (e.g., Scholl et al., 1977). A common assumption is that sediment on the oceanic plate is pelagic (e.g., red clay, biogenic carbonate ooze, chert, etc.) and easily distinguished from the terrigenous or hemipelagic sediment deposited in fore-arc basins or slopes of active margins. Drilling at Site 436 , on the ocean plate, however, illustrates the pitfalls of such an assumption, because the upper 350 meters of sediment on the incoming plate are virtually indistinguishable from the hemipelagic sediment deposited on the trench inner slope or on parts of the deep sea terrace - even as regards clay mineral assemblages (e.g., Mann and Müller and Aoyagi and Kazama, both this volume). This sediment has been windblown, icerafted, and carried in nepheloid layers or bottom currents to the site. Based on the structure seen in multichannel seismic records, Site 434 may have penetrated a portion of the "accreted" material below a subhorizontal slope sequence (see von Huene et al., this volume). Yet there appears to be no clear distinction in composition of cored material between the slope strata and the supposed "accreted" material. The preceding section on sedimentary evolution suggests that large volumes of sediment derived from the arc and fore-arc region may be redeposited at the base of the trench inner slope. Much of this material, in the form of chaotic slide or slump blocks, may be "accreted" to the leading edge of the upper plate. It would be very difficult to distinguish these sedimentary masses from tectonically disturbed hemipelagic sediment accreted from the upper part of the lower plate (e.g., Page, 1978, for discussion of relations in ancient accreted complexes). This last of course, is only one end-member example, in which much of the material on the subducted oceanic plate is derived directly from the same arc complex at which it is being consumed by subduction. There are more clear-cut examples in which the sediments on the oceanic plate and in the trench are derived from sources remote from the arc region (see Ingersoll and Suzcek, 1980) with which they converge and in which compositionally can be distinguished from sediments of the adjacent fore-arc region (e.g., along the Sunda Arc; see Karig et al., 1979). The relations demonstrated by the Japan Trench Transect, however, serve to point out loopholes in more simplistic models.

Our studies have shown that morphotectonic changes occurred rapidly in the fore-arc region off northern Honshu that may have affected the entire pattern of sedimentation. Although the slope basin model constructed by G. Moore and Karig (1976) may hold for many trenches where thick sediment sections are accreted, the evidence from the inner slope region off northern Honshu suggests that the evolution of slope basins is not steady state. They may be destroyed or filled (as in the area of Sites 441 and 434) or abruptly created (as at the midslope terrace, Site 440 , in the Plio-Pleistocene). These slope basins may be difficult to distinguish from large channels or other elongate depocenters on the deep sea terrace. The sequences in both types of basins may be separated from older sediments below by a significant angular unconformity. Thus in tectonically deformed ancient fore-arc complexes, these types of sedimentary environments will be difficult to distinguish from one another. One major tool in this case is the use of benthic foraminiferal assemblages, if they are preserved, to distinguish general paleodepth relations which might provide a clue to the environment of deposition.

Simple evolutionary models of sedimentation and tectonics in fore-arc regions (see review by Seely et al., 1974; Dickenson and Seely, 1979) cannot account for all of the features observed in the Japan fore-arc region off northern Honshu. Although the early Neogene history primarily involved rapid subsidence of the once subaerially exposed outer fore-arc region, this trend was reversed in the late Pliocene-Pleistocene on the upper trench inner slope and deep sea terrace and possibly accelerated on the lower trench inner slope. The beginning of subsidence of the Paleogene outer arc high and acidic volcanism in the fore-arc region may have been related to the termination of orogenic events in the HidakaKamuikotan orogenic belt on Hokkaido and its offshore extensions (e.g., Hashimoto, 1977; see also Moore and Fujioka, this volume) and the concomitant opening of the Japan Sea during the late Oligocene-early Miocene (see review by Kimura, 1974; Matsuda et al., 1967; Honza et al., 1977). Regional subsidence and major sediment accumulation in the Tohoku Arc region on northern Honshu began during the early Miocene and culminated in the middle Miocene in a manner similar to that of the deep sea terrace, as exemplified by Sites 438 and 439. The origin of the sudden series of tectonic events that apparently occurred during the late Pliocene-early Pleistocene time is not well understood. We suggest that it represents a period of tectonic erosion of the leading edge of the Japanese Plate (see von Huene et al., this volume). Accretion evidently has not been continuous, and our simple calculations of the volumes of accreted materials (von Huene, Nasu, et al., 1978; Arthur et al., 1978; von Huene et al., this volume) suggests that much 
less than 20 per cent of the sediment on the downgoing slab has been accreted at the leading edge of the upper plate. In fact, a large amount of cannibalism of sediment from the arc may have occurred. That is, a significant proportion of sediment from erosion of the arc complex itself may have been subducted and either "underplated" in some way at greater depth or been carried down to the upper mantle to be assimilated or melted to reappear as a component of arc volcanism.

\section{ACKNOWLEDGMENTS}

We would like to acknowledge our shipboard colleagues for stimulating discussions of some of the concepts presented in this chapter and for providing necessary data. Such a synthesis could not have been written without their contributions. In particular we thank Bobb Carson, Greta Keller, Marc Langseth, George Moore, and Nori Nasu. Greg Moore and Steve Bachman provided helpful and thoughtful reviews.

\section{REFERENCES}

Arthur, M. A., von Huene, R., Nasu, N., and Shipboard Scientists of Leg 57, 1978. Sedimentary history of a modern empty trench. Proc. Xth Intern. Congr. on Sediment., Working Group 5, Jerusalem, Israel.

Beck, R. H., Lehner, P., Diebold, P., Bakker, G., and Doust, H., 1976. New geophysical data on key problems of global tectonics: Proc. Ninth World Petroleum Congr. (Vol. 2) (Geology): London (Applied Science Publications), pp. 3-17.

Berger, W. H., and Winterer, E. L., 1974. Plate stratigraphy and the fluctuating carbonate line. In Hsü, K. J., and Jenkyns, H. (Eds.), Pelagic Sediments on Land and under the Sea: Spec. Pub. Internat. Assoc. Sediment., 1, 11-48.

Booth, J. S., 1979. Recent history of mass-wasting on the upper continental slope, northern Gulf of Mexico, as interpreted from the consolidation states of the sediment. Soc. Econ. Paleont. Mineral. Spec. Pub., 27, 153-164.

Carson, B., 1977. Tectonic modification of deep-sea sediments at the Washington-Oregon continental margin: Mechanical consolidation. Mar. Geol., 24, 289-307.

Carson, B., Yvan J., and Myers, P. B., Jr., 1974. Initial deepsea sediment deformation at the base of the Washington continental slope; a response to subduction. Geology, 2, 561-564.

Damuth, J. E., 1979. Migrating sediment waves created by turbidity currents in the northern South China Basin. Geology, 7, 520-523.

Dickinson, W. R., and Seely, D. R., 1979. Structure and stratigraphy of fore-arc region. Am. Assoc. Petrol. Geol. Bull, $63,1-31$.

Donnelly, T. W., 1975. Neogene explosive volcanic activity of the western Pacific Sites 292 and 296, DSDP Leg 31. In Karig D. E., Ingle, J. C., et al., Init. Repts. DSDP, 31: Washington (U.S. Govt. Printing Office), 577-597.

Dow, W. G., 1977. Petroleum source beds on continental slopes and rises. AAPG Continuing Education Course Notes Series No. 5: Geology of Continental Margins, D-1-D-37.

Hashimoto, S., 1977. Mesozoic and Cenozoic orogenic belts in northern Japan. Écol. Géol. de l'Himalaya, 268, Coll. Intern. du C.N.R.S., 1-6.

Hein, J. R., and Scholl, D. W., 1978. Diagenesis and distribution of Late Cenozoic volcanic sediment in the Southern Bering Sea. Bull. Geol. Soc. Am., 89, 197-210.
Hein, J. R., Scholl, D. W., Barron J. A., Jones, M. G., and Miller, J., 1978. Diagenesis of Late Cenozoic diatomaceous deposits and formation of the bottom simulating reflector in the southern Bering Sea. Sedimentology, 25, 155-181.

Hesse, R., 1977. Softex-radiographs of sliced piston cores from the Japan and Southern Kuril Trench and Slope areas. In Honza, E. (Ed), Geological Investigation of Japan and Southern Kuril Trench and Slope Areas, GH-762 Cruise Rept. No. 7: Kawasaki (Geological Survey of Japan), 86-108.

Honza, E. (Ed), 1977. Geological Investigation of Japan and Southern Kuril Trench and Slope Areas, GH 76-2 Cruise Rept. No. 7 April-June 1976: Kawasaki (Geological Survey of Japan)

Honza, E., Kagami, H., and Nasu, N., 1977. Neogene geological history of the Tohoku Island Arc System. J. Oceanog. Soc. Japan, 33, 297-310.

Honza, E., Tamaki, K., and Murakami, F., 1978. Geological Map of the Japan and Kuril Trenches and Adjacent Areas. Marine Geol. Map Series, No. 11, scale 1:1,000,000: Kawasaki (Geological Survey of Japan).

Horikoshi, E., 1976. Development of Late Cenozoic petrogenic provinces and metallogeny in northeast Japan. Geol. Assoc. Canada Spec. Paper, 14, 121-142.

Ingersoll, R. V., and Suczek, C. A., 1979. Petrology and provenance of Neogene sand from Nicobar and Bengal Fans, DSDP Sites 211 and 218. J. Sediment. Petrol., 49, 1217-1228.

Inouchi, Y., Yuasa, M., and Onodera, K., 1977. Cored materials (VIII). In Honza, E. (Ed.), Geological Investigation of Japan and Southern Kuril Trench and Slope Areas, GH 76-2 Cruise Rept. No. 7: Kawasaki (Geological Survey of Japan), 78-80.

Ishiwada, Y., and Ogawa, K., 1976. Petroleum geology of the offshore areas around the Japanese Islands. U.N. ESCAP, CCOP Tech. Bull., 10, 23-34.

Karig, D. E., and Sharman, G. F., III, 1975. Subduction and accretion in trenches. Geol. Soc. Am. Bull., 86, 377-389.

Karig, D. E., Suparka, S., Moore, G. F., and Hehanussa, P. E., 1979. Structure and Cenozoic evolution of the Sunda Arc in the Central Sumatra Region. In Watkins, J. S., Montadert, L., and Dickerson, P. W. (Eds.), Geological and Geophysical Investigation of Continental Margins: AAPG Mem. 29, 223-238.

Kennett, J. P., in press. Marine tephrochronology. In Emiliani, C. (Ed.), The Sea (Vol. 8): New York (Wiley).

Kennett, J. P., McBirney, A. R., and Thunnell, R. C., 1977. Episodes of Cenozoic volcanism in the circum-Pacific region. J. Volcan. Geotherm. Res., 2, 145-163.

Kennett, J. P., and Thunnell, R. C., 1975. Global increase in Quaternary explosive volcanism. Science, 187, 497-503. 1976. On explosive Cenozoic volcanism and climatic implications. Science, 196, 1231-1234.

Kimura, T., 1974. The ancient continental margin of Japan. In Burk, C. A., and Drake, C. L. (Eds), The Geology of Continental Margins: New York (Springer-Verlag), 817-829.

Ladd, J. W., Ibrahim, A. K., McMillen, K. J., Latham, G. V. von Huene, R. E., Watkins, J. E., Moore, J. C., and Worzel, J. L., 1978. Tectonics of the Middle America Trench offshore Guatemala. Proc. Intern. Symp. of the Guatemala 4 February Earthquake and Reconstruction Process, Guatemala City, May 1978, v. 1.

Lancelot, Y., and Larson, R. L., 1975. Sedimentary and tectonic evolution of the northwestern Pacific. In Larson, R. L., Moberly, R., et al., Init. Repts. DSDP, 32: Washington (U.S. Govt. Printing Office), 925-940. 
Ludwig, W. J., Ewing, J. I., Ewing, M., Murauchi, S., Den, N., Asano, S., Hotta, H., Hayakawa, M., Asanuma, T., Ichikawa, K., and Noguchi, I., 1966. Sediments and structure of the Japan Trench. J. Geophys. Res., 71, 2121-2137.

Matsuda, T., Nakamura, K., and Sugimura, A., 1967. Late Cenozoic orogeny in Japan. Tectonophysics, 4, 349-366.

Moore, G. F., and Karig, D. E., 1976. Development of sedimentary basins on the lower trench slope. Geology, 4, 693-397.

Moore, J. C., and Karig, D. E., 1976. Sedimentology, structural geology, and tectonics of the Shikoku subduction zone, southwestern Japan. Geol. Soc. Am. Bull., 87, 1259-1268.

Page, B. M., 1978. Franciscan melanges compared with Olistostromes of Taiwain and Italy. Tectonophysics, 97, 223-246.

Pettijohn, F. J., Potter, P. E., and Siever, R., 1972. Sand and Sandstone: New York (Springer-Verlag).

Prince, R. A., Resig, J. M., Kulm, L. D., and Moore, T. C., Jr., 1974. Uplifted turbidite basins on the seaward wall of the Peru Trench. Geology, 2, 607-611.

Sato, T., 1973. Several considerations on the deep-sea plains. Marine Sciences (Kaiyo-Kagaku), 5, 703-706.

Scholl, D. W., Marlow, M. S., and Copper, A. K., 1977. Sediment subduction and offscraping at Pacific Margins. Island Arcs, Deep Sea Trenches and Back-arc Basins, Maurice Ewing Series (Vol. 1): Washington (American Geophysical Union), 199-209.
Seely, D. R., Vail, P. R., and Walton, G. G., 1974. Trench slope model. In Burk, C. A., and Drake, C. L. (Eds.), The Geology of Continental Margins: New York (SpringerVerlag), 249-260.

Sugimura, A., Matsuda, T., Chinzei, K., and Nakamura, K., 1963. Quantitative distribution of Late Cenozoic volcanic material in Japan. Extrait Bull. Volcanologique, 26, 125-140.

Tamaki, K., Inouchi, Y., Murakami, F., Honza, E., 1977. Continuous seismic reflection profiling survey. In Honza, E. (Ed.), Geological Investigation of Japan and Southern Kuril Trench and Slope Areas, GH 76-2 Cruise Rept. No. 7: Kawasaki (Geological Survey of Japan), 50-71.

Ujiie, H., Saito, T., Kent, D. V., et al., 1977. Biostratigraphy, paleomagnetism and sedimentology of late Cenozoic sediments in northwestern Hokkaido, Japan. Bull. Nat. Sci. Museum, Series C, 3 (No. 2), 49-101.

Vail, P. R., Mitchum, R. M., Jr., and Thompson, S., 1977. Seismic stratigraphy and global changes of sea level, Part 3: Relative changes of sea level from coastal onlap. $\mathrm{Am}$. Assoc. Petrol. Geol. Mem., 26, 63-98.

van Hinte, I. E., 1978. Geohistory analysis - application of micropaleontology and exploration geology. Am. Assoc. Petrol. Geol. Bull., 62, 201-229.

von Huene, R., Nasu, N., et al., 1978. Japan Trench transected. Geotimes, 23, 16-21. 